\title{
'The Bitter Sweetness of the Space Between': Creative Reflections of Pasifika Ethnic Mixedness
}

By

Emily Fatu

A thesis submitted to the Victoria University of Wellington in fulfilment of the requirements for the degree of Master of Arts in Pacific Studies

Pacific Studies, Va'aomanū Pasifika

Victoria University

2016 


\section{Abstract}

This Master of Arts thesis investigates and draws conclusions regarding how creative arts present accommodating spaces for articulating and understanding cultural mixedness amongst Pacific populations in New Zealand. New Zealand is home to an expanding Pacific population; statistics identify a growing number of these Pacific people who are multi-ethnic, and who are claiming their mixedness in official census data. As Pacific populations have grown, Pacific artists have risen to national prominence in visual, literary and performing arts. Many of these artists have themselves been of mixed ancestry. This thesis examines the work of three female New Zealand artists of mixed Samoan-English or SamoanIndian descent, asking, "How do these artists and their work express their cultural mixedness?" Discussion centres on mixed media visual artist Niki Hastings-McFall, who is of English and Samoan descent; spoken word poet Grace Taylor, also of English and Samoan descent; and musical performer Aaradhna Patel, who is of Indian and Samoan descent. Placing both the creative work and public commentary of these three artists at its centre, this thesis explores how these artists publicly identify with their Samoan heritage as well as their other heritage(s); how they use their art as a platform for identity articulation; and how creative arts provide flexible and important spaces for self-expression. The thesis draws its theoretical underpinnings from Pacific studies, art history, transnational cultural studies and postcolonial studies, and utilizes Samoan and Tongan conceptions of vā as a key analytic tool. 


\section{Acknowledgements}

This is dedicated to my parents.

To my beloved father, Puipuia Fatu, who came from Samoa to New Zealand with nothing but clothes on his back and dreams for a better future. He wanted nothing more than the best for his children; I hope I have made him proud. To my mother, Elizabeth Fatu, the backbone of our family, a special thanks to you for your nurturing character and constant support, I would not have made it this far without you. To my sisters, Therese Fatu and Julie Fatu, thank you for your understanding and for always having my back.

To my supervisor, April Henderson, thank you for your patience, detailed commentary and knowledge. You have offered constant encouragement and excitement throughout. Thank you for seeing me through the hard yards. Without your guidance and "gentle email nudges" this thesis would not have been possible.

I would also like to thank the wider Va'aomanū Pasifika cohort for the support I have been given throughout my Pacific Studies journey that saw me to this point, particularly Teresia Teaiwa who sparked my passion for this subject and for her continuous encouragement throughout my journey. Also to Te Pūtahi Atawhai, for the space on campus that I spent most of my time writing in, and to TPA staff, particularly Jenny Taotua, and regular students for your support and confidence. To the write-on-site group, MAI ki Pōneke, thank you for showing an interest in my research, for all your advice and free lunch on Fridays.

To all my friends and family, thank you for your support, kindness and consolation. Particularly to Wiliame Gucake, for always being there for me, for proof reading and your recommendations, Kura Moeka'a and Telesia Siale for being a sounding board when I just needed to talk. I appreciate you all. Thank you. 


\section{Table of Contents}

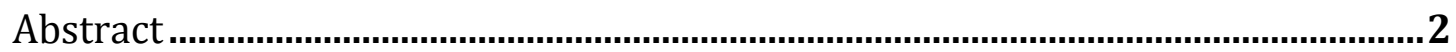

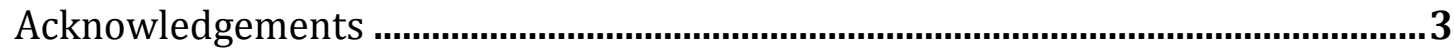

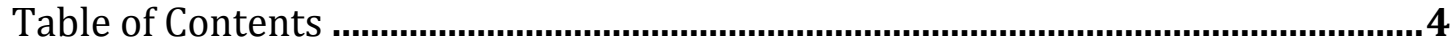

Introduction

Chapter One: Methodology and Theory …......................................................... 14

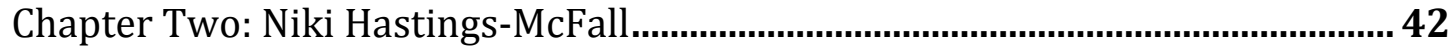

Chapter Three: Grace Taylor .............................................................................. 57

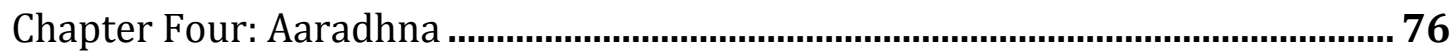

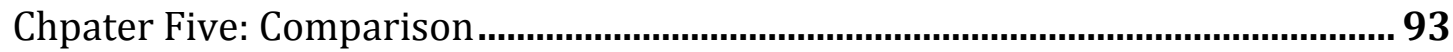

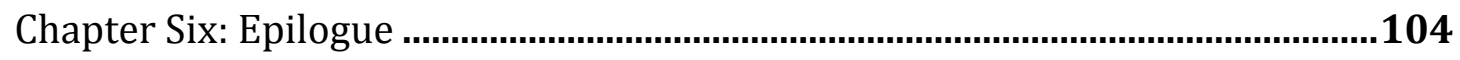

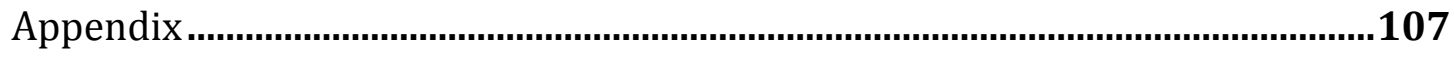

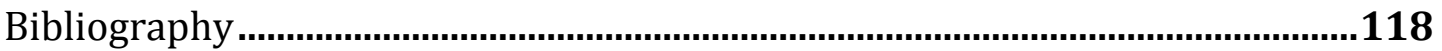




\section{Introduction}

I am the va

scatter me among yourselves

so cut me up

of the space between

and taste the bitter sweetness

and

brown

white

(Taylor, 2013)

What are people without social relationships? We, as human beings, are naturally social creatures that rely on interactions with other entities to achieve growth both internally, within ourselves, as well as externally as part of a collective. The Polynesian concept of $v \bar{a}$ characterises the bridge between ourselves and that to which we are trying to connect. Vā is a term for conceptualizing socio-spatial relationships-between people, between people and their environments, and between people and $\operatorname{god}(\mathrm{s})$ (Lilomaiava-Doktor, 2009). The need to maintain and nurture social relationships is of utmost importance for achieving a sense of balance and harmony within ourselves. This is why the concept of vā is critical to this thesis in terms of understanding what it truly means to be of mixed descent.

Neither brown, nor white, poet Grace Taylor writes of her experiences of being somewhere in-between. A bittersweet place "between ignorance and acceptance" (Taylor, 2013). We live in a nation where others want to categorise and organise us (Mila-Schaaf, 2011). Taylor explores the complexities of this, particularly for those who are of mixed descent. This passage from Taylor's poem 'I am the va' (2013) touches on some of the experiences of being "inbetween", unable to be placed neatly into the boxes that society has constructed. This thesis hopes to explore the phenomenon of "in-betweenness" experienced by people of mixed Pacific ancestry in New Zealand in more depth. It does so by 
delving into the contemporary world of the creative arts, examining how three artists of mixed Samoan descent express their mixedness through poetry, musical performance and mixed media art.

New Zealand is home to an expanding Pacific population ${ }^{1}$. Statistics identify a growing number of these Pacific people who are multi-ethnic, and who are claiming their ethnic mixedness in official census data (Statistics New Zealand, 2008; 2014). The 2013 New Zealand census examined the rates of people identifying with multiple ethnic groups, and found they were the highest in younger age groups and amongst those recording Māori or Pacific as one of their ethnic groups (Statistics New Zealand 2014).

As discussed later in this thesis, literature about Pacific experiences of identity and wellbeing in New Zealand frequently indicates recurring themes of struggle associated with cultural mixedness, for example feeling different in a wider ethnic community and being faced with issues or confusion surrounding personal identity (Fairbairn-Dunlop \&Makisi, 2003; Hall, 1996; Tiatia, 1998; Keddell, 2006, 2009; Macpherson, 1999; Macpherson, Spoonley \& Anae, 2003; Manuela \& Sibley, 2012; Mila-Schaaf, 2010, 2011; Mulitalo, 2001). There is some research, however, that casts experiences of mixed identity in a more positive light, looking specifically at New Zealand-born Pacific people in New Zealand and discussing how valuable a skill it is to be able to function in multiple contexts (Mila-Schaaf \& Robinson, 2010).

As Pacific populations have grown in New Zealand, Pacific artists have risen to national prominence in visual, literary, and performing arts. Many of these artists have themselves been of mixed ancestry (Brunt et al, 2012; Mallon \& Pereira, 1997, 2002; Mila-Schaaf, 2011; Teaiwa, 2007; Tusitala Marsh, 2006; Whimp, 2009). A number of these artists have addressed mixedness either explicitly or implicitly in their work, and/or in the contextualisation of their

\footnotetext{
1 People in New Zealand who have descended from migrants from the Pacific besides New Zealand Māori.
} 
work via exhibition catalogues, interviews and in other publicity materials (Mallon, 2004; Mallon \& Pereira, 1997).

Sean Mallon and Pandora Fulimalo Pereira, authors and editors of multiple texts on Pacific arts and artists in New Zealand (1997; 2002), discuss the rising recognition of Pacific peoples' achievements in the arts over the past four decades. Artistic mediums allow expression and exploration of tradition, cultural values and self-identity (Brunt et al, 2012; Mallon, 2004). From the blooming population of early Pacific migrants during the 1950s to 1970 s came the emergence of the 'New Zealand-born' population. As New Zealand-based art historian Karen Stevenson (2008) suggests, they are from a generation that have a foot in two cultures, who have brought to the table inspiration from their parents' homelands while simultaneously carving unique spaces as Pacific people in New Zealand. Today, Pacific designs, motifs, histories and stories are a large part of New Zealand culture (Mallon \& Pereira, 1997).

Critical writing in Pacific Studies places importance on the role of artists in society. In Albert Wendt's 1976 essay “Towards a New Oceania,” he stressed connections among artists across the region, drawing specific attention to poets/writers, visual artists, musicians and dancers. Wendt declared,

Across the political barriers dividing our countries an intense artistic activity is starting to weave firm links between us... this artistic renaissance is enriching our cultures further, reinforcing our identities/self respect/ and pride, and taking us through a genuine decolonisation; it is also acting as a unifying force in our region. In their individual journeys into the Void, these artists, through their work, are explaining us to ourselves and creating a new Oceania (1983: 81-85).

Following in the steps of Albert Wendt, Cluny Macpherson in a 1999 article also discusses how new identities are being expressed and redefined for young Samoans, and how different art forms have been a place for these ideas to be 
articulated. Macpherson suggests that New Zealand-born Samoans are taking elements of Samoan culture, sifting through their own experiences and using that to build their own new and distinctive identity. For example, elements of traditional dance are woven through modern dance, religious music has been mixed with popular music including rap, and Samoan clothing designers have taken traditional motifs and incorporated them into their creative design. While not addressed by Macpherson, another salient example of this creative mixing occurs with Samoan tatau, or tattooing, (Mallon, 2010). Such observations about the importance of art forms as spaces for identity expression are similarly made by a range of other Cultural Studies and Pacific Studies scholars (Diaz \& Kauanui, 2001; Hall, 1993; Hereniko, 1999; Hau'ofa, 1998; Teaiwa \& Marsh, 2010; WesleySmith, 1995; Wood, 2003).

\section{Thesis Aim}

Recognising two concurrent trends-the increasing population of ethnically mixed Pacific people, and the rising prominence of Pacific artists addressing themes of mixedness - this Master of Arts thesis investigates and draws some conclusions regarding how creative arts present accommodating spaces for articulating and understanding cultural mixedness amongst Pacific populations in New Zealand. It does this by examining the work of three female New Zealand artists of mixed descent, asking, "How do these artists and their work express their cultural mixedness?"

This thesis focuses on mixed media visual artist Niki Hastings-McFall, who is of European and Samoan descent, has mounted work in numerous solo and group exhibitions over her 15+ year career, and has had work purchased by Museum of New Zealand Te Papa Tongarewa, The British Museum, The University of Auckland and Victoria University of Wellington for their collections; spoken word poet Grace Taylor, also of European and Samoan descent, a co-founder of South Auckland Poets Collective and Rising Voices Youth Poetry movement and the 2014 Creative New Zealand Emerging Artist Award winner; and musical performer Aaradhna Patel, who is of Indian and Samoan descent. Aaradhna is a 
multiple Tui Award and Pacific Music Award recipient. Similar to the positive deviance approach employed by Mila-Schaaf and Robinson in their 2010 studywhich chose to focus on a range of successful New Zealand Pacific professionals rather than focus on people who faced many barriers, or people who were presented as a "problem" from the perspective of social services-I choose these artists because I perceive them as successful role models and professionals.

Placing the work of these three artists at its centre, this thesis then asks: How do these artists publicly identify with their Samoan heritage as well as their other heritage(s)? How do the three artists use their art forms as tools for their own identity expression? Do creative arts provide flexible spaces for self-expression? With these questions in mind, this thesis will also offer analysis of the art produced by these artists, exploring distinctive themes and discussing how their art can be interpreted as expressing ethnic mixedness.

The topic of Pacific mixedness is of interest to me because of my ethnic background and upbringing, and constant feeling of living on the edge or in the 'in-between' of my ethnic make-up-not fully belonging to any one ethnic group (Mila-Schaaf, 2011). I am the daughter of a Samoan father who migrated to New Zealand and a New Zealand-born Pākehā/Māori mother. I was born and raised in Wellington, New Zealand, and was not taught to speak Samoan or any other language belonging to my ethnic mix apart from English.

"Who are you?", "What are you?”, "Where are you from?": these are the frequently asked questions that I have encountered in life from strangers, peers, friends, acquaintances and associates who have crossed my path. It's become so normal for me that I often find myself asking these same questions of other people. In her $2011 \mathrm{PhD}$ thesis, Karlo Mila-Schaaf interprets vignettes from others' identity stories. Drawing from these, her discussion suggests that New Zealanders have something of an obsession with wanting to know who someone is, where they are from, and what they identify as, so that they can relate, organise, categorise, judge or place a person according to their answer (MilaSchaaf, 2011) My mixed ethnic background has at times made it difficult to place 
me: I have been mistaken for a Cook Islander, Tongan and even Fijian, normally by Pacific people themselves. Though I have not experienced much overseas travel, my older sister lived in London for a short period and, travelling much of Europe and other various countries, she would also often get asked, mainly by other people of colour, "where are you from?" or "what are you?" When she responded with "I am a New Zealander," they would then often reply saying, "yes, but where are your parents from? - I see something in you". My sister's experiences demonstrate that curiosity and wanting to know where someone is from go far beyond the borders of New Zealand.

When I am asked the aforementioned questions, I often refer to the heritage of my parents, closely followed with the place of my birth, because often in the past I have received comments that sometimes put me in a position that I'd rather not be in. For example, if I identify myself solely as "Samoan" to others who identify as Samoan, especially in my parents' generation and older, they've then attempted to continue a conversation with me in the Samoan language. This has been difficult for me as I don't understand nor speak the language and I sometimes felt that I was being subjected to expectations after making claim to my heritage (see also Gershon, 2007; Mila-Schaaf, 2011). On occasion I have seen the disappointment in people's expressions after learning that I have little understanding of the language, which has at times left me feeling embarrassed and disappointed in myself for not knowing nor taking on that responsibility to learn it. I also felt I was missing an opportunity to learn or hear experiences from someone else in a language they are most comfortable with. At some point in my late teenage years and very early twenties, being asked so often "what are you?," and then claiming my heritage while not being able to deliver what I felt was expected of me, started to have an impact. I then started asking the question, where do I fit? (see also Mila-Schaaf, 2011).

While the topic of mixed Pacific identity is therefore very personal for me, this thesis enables me to build and extend beyond my own personal context by exploring the experiences of other mixed Pacific people in New Zealand, identifying commonalities and differences between their engagements with and 
expressions of their mixedness. This essay also builds upon my interests in Pacific arts, and undergraduate coursework in art history, by focusing its comparative lens on three contemporary New Zealand artists of mixed Pacific ancestry, exploring in particular how their mixedness is engaged or expressed through visual arts, poetry and music.

\section{Thesis Structure}

Chapter One provides contextualisation of the rising rates of populations of Pacific ancestry in New Zealand, exploring the phenomena of Pacific migration and diaspora. This chapter also explores Pacific mixedness and mixed identities that have been constructed in New Zealand due to the movement and relocation of Pacific migrants. It then discusses the philosophical underpinnings of the thesis, which draw from a transnational Cultural Studies and Pacific Studies approach, and outlines, synthesises and summarises key facets of the theoretical and methodological frameworks that I apply in my research. This includes discussions of the Samoan concepts vā and teu le vā as well as the Tongan cognate concept tauhi vā. This theoretical section also briefly explores other relevant theoretical concepts such as hybridity and interstitiality, and discusses methods employed in the research.

Chapter Two provides background information on Niki Hastings-McFall, examining important milestones in her life and career that have led her to her art expression and the rising prominence of her involvement in the arts. To contextualise Hastings-McFall's work, there is a brief discussion regarding the rising rates of Pacific artists and the recognition that Pacific art now has in New Zealand. This helps demonstrate how the arts have been a space where Pacific people continue to thrive in New Zealand. This chapter then analyses and contextualises the themes Hastings-McFall explores in her mixed-media art, and concludes with discussion relating her artwork to the concept of vā and to the freedom she feels in the "liminal space". 
With a similar structure, Chapter Three provides background on poet Grace Taylor. It also provides background on the art of spoken word poetry and Taylor's involvement in the growth of spoken world in New Zealand. The chapter then explores the themes that are present in Taylor's poetry, with a focus on the poems in her 2013 publication, 'Afakasi Speaks, and her theatre production, My Own Darling (2015). A common term and concept present in Taylor's poetry is 'afakasi-a term closely associated with mixedness, as is discussed in more detail in this chapter. This chapter concludes with analysis of how Taylor's work engages with vā, highlighting the importance of actively. Nurturing relationships-to teu le vā and tauhi vā-in order to not disrupt the vā.

Chapter Four then provides a brief background on Aaradhna Patel, a recording artist and performer. Similar to the two preceding chapters on artists, it discusses her background and some of the important milestones in her life that helped her get to where she is today. This chapter also reviews the music genre of RnB, and some of Aaradhna's musical influences that have affected the development of her sound. It then explores several key themes that are present in her music. Similarly to Chapters Two and Three, this chapter then concludes by drawing on the concept of vā and exploring how nurturing relationships (teu le vā and tauhi vā) can bring a sense of peace to individuals.

Chapter Five comparatively analyses the three artists' engagements with their mixed cultural heritages through their work and through comments that they have shared publicly, or, in the case of Hastings-McFall, in an interview for this thesis. Drawing on the concepts of tauhi vā and teu le vā, this culminating substantive chapter of the thesis explores and compares how these artists actively articulate and maintain their cultural connections and engagement with the various aspects of their multi-ethnic identities. Comparative research has proved to be useful as a mode of enquiry in the field of Pacific Studies (Howe, 1979). Past comparative research showed that there is a better understanding of mixedness gained while comparing work of more than one artist (Fatu, 2013). 
Comparing different genres of art has also afforded additional insight that otherwise may not have come to the fore.

The Epilogue succinctly recaptures the important findings in the thesis and clearly outlines what this research does and doesn't do. Most importantly, the Epilogue discusses what this research offers and why it is valuable. 


\section{Chapter One: Methodology and Theory}

\section{Pacific Migration and Diaspora}

Migration is not a new phenomenon to the $21^{\text {st }}$ century; there is an extensive history of people moving from place to place for centuries, and this has been influenced by many push and pull factors. The Pacific is no exception (FairbairnDunlop \& Makisi, 2003; Ferro et al, 2006; Macpherson et al, 2001; Spickard et. al 2002). Of course the Pacific islands were themselves settled by traveling migrants over a vast period between 60,000 and 500 years ago, with the continental high island of New Guinea and Australia being the first land masses in the Pacific region that were inhabited (Howe, 1988). As Pacific historians note, migration did not cease with settlement; stories of interisland journeys abound in narratives transcribed by early European visitors. Historian David Chappell writes of the widespread enlistment of Pacific sailors on European ships in the $19^{\text {th }}$ century, noting that vessels were in some cases specifically constructed or acquired by Pacific people (usually of chiefly status), that helped unite distant islands (Chappell, 1997). Looking specifically at Samoa, another Pacific historian, Damon Salesa, highlights travel and mobility as absolutely central to Samoan conceptions of their island homeland (Salesa, 2003).

Pacific Island people from Samoa, Fiji, Guam, Hawai'i, Cook Islands and many more island nations have been moving between villages, cities, islands and Pacific periphery nations since the early $20^{\text {th }}$ century (Spickard et al, 2002). It was, and still is, common that the current or former colonial administrator of an island nation exerts influence over what metropolitan country migrants go to. Due to New Zealand having a history of colonial administration over the Cook Islands, Tokelau, Niue and Samoa, many migrants from these locations traveled to and settled in New Zealand (Macpherson et al, 2001). During the 1960s and early 1970s, New Zealand was experiencing economic expansion and labour shortages, and additional labour was sought in the Pacific islands. This created a 
chain migration from the islands, as those already in New Zealand spread word of opportunities for work. Due to the concentrations of migrants in particular urban neighborhoods around New Zealand, islanders were able to interact with others from their home nations, keeping social networks through church, sports and other associations (Macpherson et al, 2001; Mallon et al., 2012; Spoonley \& Pearson, 2004). During this period of high labour demand, enforcement of visa limits was comparatively lax. Political and economic shifts and a reduced demand for labour in the early-mid 1970s, however, ended this period of leniency and resulted in the "dawn raid" episodes of 1974 and 1976, when many Pacific Island "overstayers", particularly those of Samoan and Tongan descent, were deported back to their homelands (Anae, 1997; de Bres, 1999; de Bres and Campbell, 1975). Despite the discrimination, the flow of Pacific migrants into New Zealand was relatively smooth because at the time New Zealand's policy favoured less expensive, better educated young migrants, including young women migrants from the plantations (Liki, 2009: 540).

Statistics New Zealand (2013) has identified a wide diversity of Pacific peoples in New Zealand today, outlining how the Pacific population comprises of 20 Polynesian, Melanesian and Micronesian cultures, including an even more diverse range of languages. New Zealand's population has reached over 4.5 million, of which approximately 340,000 are Pacific people. Statistics New Zealand outlines the seven largest Pacific populations in New Zealand as being Samoan, Cook Island Māori, Tongan, Niuean, Fijian, Tokelauan, and Tuvaluan. Of those seven, the largest Pacific ethnic group in New Zealand is Samoan, making up 144,138 Samoan people. $62.7 \%$ of the Samoan population $(89,271$ ) is New Zealand-born. The Cook Islands population is the second largest, making up a total of 61,839 Cook Islanders, closely followed by the Tongan population with a total of 60,336 people, and the Niueans with 23,883 people. These numbers show that in New Zealand a large portion of the Pacific population is from the Polynesian region.

The Fijian population is the fastest growing Pacific community in New Zealand, with a 46.5\% increase between 2006 and 2013. Despite this, they still only made 
up 14,445 of the New Zealand population. The Tokelauan population follows with 7,176 total, while the smallest of the seven groups is the Tuvaluan population making up a total of 3,537 people. In addition to these seven are smaller populations of other Pacific peoples, such as I-Kiribati, Papua New Guinean and Solomon Islanders (Statistics New Zealand, 2014).

Increasingly, Pacific people are forming reproductive unions with peoples from other ethnic backgrounds, and now many New Zealand Pacific people are identifying with multiple ethnic groups and cite this mixed ancestry demographically - a phenomenon that is accommodated in the New Zealand census collection. According to Cluny Macpherson (1999), rates of intermarriage between specifically Samoan migrants and other ethnic groups were significant as far back as the 1970s: "in the mid-1970's one in every three Samoans marrying was taking a non-Samoan partner. If defacto relationships were included in this calculation it is likely that about one in every two Samoans was entering a relationship with a non-Samoan" (1999: 55). The children of these unions are captured in recent NZ census data, in which 24\% of Samoans reported one other ethnic group, while $14 \%$ reported two or more other ethnic groups. For the Tongan population in New Zealand, 20\% reported one other ethnic group, and $12.5 \%$ reported two or more other ethnic groups. The Niuean population reported the highest rate of ethnic mixture, with $37 \%$ reporting one other ethnic group, while $28 \%$ reported two or more other ethnic groups, (Statistics New Zealand, 2014).

As the evidence above supports, migration was and is a prevalent phenomenon throughout the Pacific. The term diaspora has been used to characterise the complex senses of belonging, attachment, and transnational relationships rising from migration. Originating as a way to characterize the historical dispersions of Jewish (and subsequently Greek and Armenian) populations, the term is now applied more widely to "groups who imagine themselves as transnational communities whose primary affiliations and loyalties (with coethnic others living elsewhere, including the homeland) lie beyond the boundaries of the 
nation state" (Ang, 2005: 83). Many theorists have explored ideas of diaspora, (Bennett et al, 2005; Clifford, 1997; Safran, 1991).

The term diaspora literally means the scattering of seeds, and refers to the dispersal of people from an original homeland. Historically, this dispersal was normally of a traumatic nature due to the feelings of displacement from the ancestral homeland, and the term can carry negative and political connotations due to the experience of being isolated and exiled (Ang, 2005; Clifford, 1997). In James Clifford's essay, “Diasporas”, he offers a summary of William Safran's definition of diaspora:

expatriate minority communities" (1) that are dispersed from an original "center" to at least two "peripheral" places; (2) that maintain a "memory, vision, or myth about their original homeland"; (3) that "believe they are not-and perhaps cannot be-fully accepted by their host country"; (4) that see the ancestral home as a place of eventual return, when the time is right; (5) that are committed to the maintenance or restoration of this homeland; and (6) whose consciousness and solidarity as a group are "importantly defined" by this continuing relationship with the homeland (Clifford, (1997:5) citing Safran, 1991: 83-84)

Safran's definition of diaspora implies that diasporic experiences encompass all of the characteristics outlined above; he has rationalised this based on historical events. However, Clifford argues that although it is important to recognise the importance of such characteristics for shaping the language of diaspora, they shouldn't constitute the definitive model. As Ien Ang explains in her concise essay on the term and history of the concept, 'diaspora' has shifted in meaning over time: now, "'diaspora' signifies the constant renewal of identity through creative hybridity and transformation under the very condition of dispersal and difference, rather than the need to return to one's 'roots.' In other words, in the 
postmodern meaning of 'diaspora,' the organic link between people and homelands has been severed." (Ang, 2005: 84).

The term diaspora is relevant for conceptualising what Pacific migrants may feel in New Zealand, and an understanding of diasporic experience enhances discussions of Pacific mixedness and identity. Concepts of diaspora aid in understanding the differing experiences of first generation Pacific migrants in comparison to their New Zealand-born children, and the ways multilocal attachments and multifaceted identities may develop or persist across generations of Pacific people in New Zealand.

\section{Pacific Mixed Identity}

A significant body of international literature explores themes of intermarriage/interracial relationships/multi-ethnicity and multi-ethnic identity (Hall, 1996; Phinney \& Devich-Navarro, 1997; Spencer, 2014; Spickard, 1989). The terms "interracial," "multiracial" or "mixed-race" are more commonly used in international literature, particularly that originating in North America where they are often used interchangeably. New Zealand literature tends to instead refer to "multiple ethnicities." The literature that I draw on specifically for this thesis uses terms such as "multi-ethnic" (Mila-Schaaf \& Robinson, 2010; Manuela \& Sibley, 2012; Keddell, 2006; 2009), “mixed-race” (Hall, 1990; Diaz \& Kauanui, 2001; Keddell, 2009), "polyethnic" (Macpherson, 1999) and "afakasi” (Macpherson, 1999) when referring to peoples who identify with two or more ethnicities. Not all of these terms can be used interchangeably; rather, each is deemed appropriate for use within certain contexts. In this thesis I will be using the terms mixed and multi-ethnic interchangeably to refer to those with multiple ethnicities because these terms are similar in meaning and more common in New Zealand literature.

Of course, relationships leading to multi-ethnic Pacific offspring have a much longer history that precedes Pacific migration to New Zealand. As mentioned 
earlier, long histories of Pacific interisland travel ensured that children were born to unions of Pacific people from different islands. In fact, in the central Pacific, such unions and the children they produced were of strategic social and political significance (Kaeppler 1978). Later, European explorers, traders, and settlers arrived, as did Chinese, Indian and other labourers, and they too were involved in relationships with the indigenous island populations. Pacific people continued to travel between islands for job opportunities in the $19^{\text {th }}, 20^{\text {th }}$, and $21^{\text {st }}$ centuries: Samoans went to Fiji (Tuimaleali'ifano, 1990) and Fijians to the Solomon Islands (Ferro et al, 2006). Many from Melanesia migrated to Australia to work in the sugarcane fields (Ferro et al, 2006), or to Samoa to work on copra plantations (Meleisea, 1980; Liki, 2009).

Significant movement of Pacific people has resulted in diverse cultural identities shaped by the various experiences that individuals have in the places they now inhabit. In the New Zealand context, the theme of mixedness can refer to cultural mixedness as well, which is recognized in New Zealand literature specifically around themes of Pacific identity (Fairbairn-Dunlop \& Makisi, 2003; Macpherson et al, 2001; Tiatia, 1998). Engaging this literature, I noted that first and second generation New Zealand-born Pacific islanders who were mono-ethnic (i.e identify with one ethnic heritage) faced similar identity issues as those that had multiple ethnicities. The most common correlation between the two groups was the recognition of the dualities of their lives-trying to sustain one's instilled Pacific cultural values while simultaneously being exposed to the Westernized New Zealand culture. Despite broader commonalities, however, each individual has his or her own story. The book Making our Place: Growing up PI in New Zealand, edited by Peggy Fairbairn-Dunlop and Gabrielle Sisifo Makisi (2003), contains a collection of stories from a range of diverse Pacific people who grew up in New Zealand who each recollect their own experiences. Melani Anae was one of these people and a significant proportion of her academic research pertains to the topic of Samoan identity in NZ. In her $1998 \mathrm{PhD}$ thesis, Fofoa-IVao-'ese: The Identity Journeys of NZ-Born Samoans, Anae discusses her experiences of being Samoan in New Zealand, highlighting a sense of betweenness. 
I am- a Samoan, but not a Samoan...

To my 'aiga in Samoa, I am a Palagi

I am- a New Zealander, but not a New Zealander...

To New Zealanders I am a 'bloody coconut' at worst, a 'Pacific

Islander' at best

I am- to my Samoan parents, their child, (Anae, 1997:128, in

Anae, 1998: 2)

These lines are the 'identity verse' that formed the heart of her thesis; the lines are oft-quoted and have now been adopted by others. It is a verse that many NZborn Pacific people can relate too. Melani Anae, who was born in New Zealand, felt caught between cultures as a young adult before discovering her identity. She tells of her blissful childhood, where being a kid meant just that: she didn't see herself as a Samoan or a New Zealander, she was just a kid. She explains it wasn't until secondary school where she noticed feeling different from her peers, and thus her focus was on her education, which consequently led to high achievement in academia and extra-curricular activities. Despite this, her identity journey turned full circle and she expresses that she has never been more secure in who she is, she accepts that she is her Samoan parents' child who had the fa'aSamoa values they brought with them instilled in her; she is a product of the migrant dream-the Pacific diaspora. Anae indicates how she now identifies as a New Zealand-born Samoan and balances her responsibilities to her church and 'āiga both in New Zealand and Samoa, as well as her role in education as an academic.

Similar themes are expressed across a range of New Zealand Pacific scholarship (Fairbairn-Dunlop, 2003). Macpherson, (1999) who has conducted extensive research on Samoan culture, customs and migration patterns in New Zealand, argues that descent and social identity do not perfectly correspond; descent is established at birth and is fixed whereas social identity is much more fluid, "it can be chosen, constructed and reconstructed, albeit within bounds set by a society" (1999: 51). Macpherson points out that the second generation (though 
he does not use this precise term) has fewer similarities in identity to the immigrant generation, which can possibly be the cause for those in this generation to feel 'caught between cultures'. (1999: 51).

Literature on Pacific experiences of identity and wellbeing in New Zealand often recounts people's experiences of feeling different in a wider ethnic community, and their struggles with personal identity (Fairbairn-Dunlop \& Makisi, 2003; Hall, 1996; Tiatia, 1998; Keddell, 2006, 2009; Macpherson, 1999; Macpherson, Spoonley \& Anae, 2003; Manuela \& Sibley, 2012; Mila-Schaaf, 2010, 2011; Mulitalo, 2001). For example, Sam Manuela and Chris G Sibley (2012) undertook two quantitative studies investigating why Pacific people with multiple ethnic affiliations have poorer subjective wellbeing compared to those that identify as mono-ethnic Pacific. In a New Zealand national population where Pacific ethnic groups are demographically the minority, their study suggests that New Zealand Pacific individuals who have, through their parents, ethnic affiliations with both a majority group (European) and minority group (Pacific) will be more likely to internalize negative stereotypes and decreased positive affiliation towards their minority (Pacific) rather than majority (European) group membership.

In contrast to Manuela \& Sibley's findings, Melani Anae states in her essay “Teu Le Va: Toward A Native Anthropology" that many New Zealand-born Samoans self-identify as Samoan or New Zealand-born Samoan despite their being of mixed heritage or a New Zealander according to their official birth place (2010:228). She elaborates, saying,

As ethnic minorities in New Zealand, ethnic identity, in the context of opposition and conflict is therefore personal with emotional long-lasting attachments experienced in the economic, spiritual, historic symbols that one is exposed to during a lifetime, and must be differentiated from the statuses which are transient and not emotionally binding, but a mere fact of circumstance (Anae, 2010:228). 
Anae further elaborates by offering her personal example of this: "I define my ethnic identity as a New Zealand-born Samoan woman because I am more emotionally tied to the imminent existential identities of 'New Zealand born Samoan' and 'woman' (mother, sister, daughter, etc) rather than my other statuses... (academic, teacher, anthropologist, pianist, etc)" (2010: 229). Anae further comments, "our ethnic identity is thus situated historically, socially, politically, culturally, but more importantly emotionally through the stories told to us by our matriarchs-mothers, grandmothers, even fathers who have been strongly influenced by their mothers." (2010: 229) Anae therefore is indicating that individuals will identify and define themself with what they are emotionally tied to because their ethnic identity must be one they can live with.

Anae's discussion reaches a different conclusion from Manuela \& Sibley's research results; however, both highlight that people's identity affiliation and attachment is due to an emotional stimulus, regardless of whether it was positive or negative.

Emily Keddell (2006) conducted research on participants identifying with Samoan-European mixes in New Zealand. In her essay, "Pavlova and pineapple pie: Selected identity influences on Samoan-Pakeha people in Aotearoa/New Zealand", she found that in some cases, for her participants, their Samoan identity is challenged when they do not conform to strict ideas about what Samoan culture consists of; those that are New Zealand-born and are multiethnic, in particular, perceived demands by both minority and majority groups that they display Samoan legitimacy.

The literature indicates that in the development of our claimed identities, Pacific people who are not literally of mixed descent share similar feelings to those that are: people raised in New Zealand with two Samoan parents may still feel "mixed" and even those that are not of mixed ethnicities struggle with balancing their indigenous cultures while living in New Zealand. In some cases this can be even more difficult for Pacific mono-ethnic individuals compared to their multiethnic counterparts, because it can create a greater pressure to display 
legitimacy when they only have one Pacific ethnicity as their heritage. This became apparent when reviewing the abundant supply of New Zealand literature on Pacific diaspora communities. (Fairbairn-Dunlop \& Makisi, 2003; Hall\& Du Gay, 1996; Tiatia, 1998; Macpherson, Spoonley \& Anae, 2003; MilaSchaaf, 2011; Mulitalo, 2001).

An example of this can be assessed in Jemaima Tiatia's (1998) book, Caught between cultures: A New Zealand born Pacific Island perspective. This explores the plight of being a Pacific Islander in a Westernised society, and feelings of being unappreciated despite being able to offer something that is very unique to European society. As well as the discussion around the struggle for Pacific Islanders in a Western society, Tiatia also explored the reverse, being ignored by other Pacific Islanders due to the possible "threat" New Zealand born Pacific Islanders pose to essentialised ways of thinking.

This variance in attitudes towards mixed Pacific individuals can present very conflicting and confusing situations, and can have an influence during the formation of one's cultural identity. Lived experiences of mixedness are complex, and require nuance to interpret. In order to analyse the complexity of ethnic mixedness and the experiences of mixed Pacific people in New Zealand, this thesis draws from the fields of Cultural Studies and Pacific Studies.

\section{Cultural Studies and Pacific Studies}

Five years ago at Victoria University of Wellington, in my second year after taking a variety of miscellaneous papers, I discovered Pacific Studies-originally recommended as an interest paper to me. Pacific Studies explores issues and addresses topics that are both interesting and relatable to me; I appreciate its fluidity and attention to marginalised, minority Pacific groups in New Zealand. This experience changed my perspective on heritage and culture, and influenced my overall degree choice from there on. Pacific Studies is the study of the Pacific region, encompassing Micronesia, Melanesia and Polynesia, and draws on prominent disciplines such as History, Anthropology and Geography, closely 
followed by Political Science and Sociology (Diaz \& Kauanui, 2001; Teaiwa \& Henderson, 2009). It is an interdisciplinary and multi-disciplinary field of study, which can change depending on perspective and location. Having this inter- and multi-disciplinary lens is crucial for Pacific Studies as it is impossible for a single discipline to convey the complexities of culture and diversity within the Pacific. Particularly at Victoria University, Pacific Studies commits to an approach emphasising interdisciplinarity, comparativity and indigeneity, (Whimp, 2008). This approach encourages research that benefits the Pacific and Pacific communities.

Pacific Studies is able to open up a space that addresses Pacific minority group(s) in New Zealand, and Pacific people across Oceania. Cultural studies, also with an interdisciplinary lens, similarly opens up a space that particularly addresses minority groups and marginalised groups. The Centre for Contemporary Cultural Studies (CCCS) at the University of Birmingham, also known as the Birmingham School, became very influential in the 1970s-2000s on scholarship in the humanities and social sciences worldwide. It is possible that it became influential because of its political edge; it retained the politics of Marxism that proposed the importance of class distinctions, which underscored the imbalances of power in a capitalist society, while also allowing for critical discussions of culture, race, ethnicity, and, to a lesser extent, gender (Morley \& Chen, 1996; Webster, 2004). "Cultural Studies analyzes the relationship among culture, knowledge, and power, from historical, social, and theoretical contexts, and is concerned with how knowledge, texts, and representations are produced and appropriated in relation to power structures" (Pumar, 2005: 5).

Generally when scholars think of Cultural Studies, they usually think of Stuart Hall, a well-known Jamaican-born sociologist who served as the director of CCCS from 1964-1979. Hall spent his childhood schooling in Jamaica and then received a Rhodes Scholarship and attended Merton College, Oxford, in England, which he later referred to as the 'center of the center' (Hall \& Sakai, 2005) - the land of opportunity and education. A point of comparison can be made here to New Zealand being the "land of milk and honey" to many Pacific migrants that 
voyaged here for similar opportunities. Since the 1970s, Stuart Hall has been one of the most influential theorists of race, identity, media, and communications in the Anglophone world, who went further to recognize other categories of difference alongside class, such as race and gender. Hall's theorisations of race and identity are influenced by his situatedness in African-Caribbean and United Kingdom contexts. Hall's work and contributions to Cultural Studies are still very influential; however, when Cultural Studies traveled abroad and reached the Pacific, Pacific scholars found that British cultural studies does not accommodate or handle the concept of indigeneity in a way that is relevant or useful for the Pacific region, (Teaiwa, 2005) so Pacific theorists hoped to establish and adapt a Cultural Studies applicable to Oceania.

In his 2003 essay "Cultural Studies for Oceania”, Houston Wood discusses exactly this and identifies the need for a Cultural Studies for Oceania that will rely on diverse native concepts, theories and perspectives. Wood's essay outlines other necessities, including the requirement for reciprocities and the need to revive and reinvent traditional epistemologies that are valid for community-based research, such as acknowledging and valuing the community's oral legacies, knowing that Pacific people of today have evolved from a complex oral society.

Vicente M. Diaz and J. Kēhaulani Kauanui collaborated to write "Native Pacific Studies on the Edge", a 2001 essay introducing a special journal issue arising from a conference of the same name. In the essay, they sought to triangulate the arenas of Native Studies, Pacific Studies and Cultural Studies. Central to Native Studies is the struggle for sovereignty and decolonisation. Diaz and Kauanui define The Native as being "self- and collectively identified through genealogy as well as through imposed categories such as race and blood, and through native perspectives, sources, values, and lifeways" (2001:318). Similar to what Wood hoped for a Cultural Studies for Oceania, in Diaz and Kauanui's essay they too see a need for more native-based research, theory and methodology for Native Pacific Cultural Studies. In their essay they also discussed the importance of having a deep-rooted sense of place, as well as native language and indigenous discourse and the arena of spiritual faith in multiple forms-myths and legends 
as well as Christianity. Kauanui and Diaz continue to explore the different aspects of the discourses that make up Native Pacific Cultural Studies.

Pacific Studies tries to keep pace with local, regional, national and international interests through academic cooperation and collaboration, with the disciplines already mentioned at its forefront. Pacific Studies also helps generate Pacific Island scholars. Teresia Teaiwa centres her work on Pacific studies while also examining the importance of Cultural studies. Teaiwa argues, "what Cultural Studies has to offer that decolonization often neglects in its activist impulses is the opportunity to consider the complex layerings of culture, politics, economics, history and so on that make change both necessary and difficult" (Teaiwa, 2005: 23-24). This undercurrent is an essential foundation to Cultural Studies. Cultural Studies helps us grapple with the idea that culture and identity is neither innocent nor pure, and neither is scholarship on culture and identity because of the constructed and contested nature of cultures and identities.

Both Pacific Studies and Cultural Studies are part of the framework and foundation for this thesis and I draw on both to think about and theorise identity and mixedness. One of Hall's influential works that is specifically of use for this thesis is his 1993 essay, "Cultural Identity and Diaspora." In the essay he established two very different ways of understanding the concept of identity. The first position Hall outlines interprets identity as about "one shared culture, one true self hiding behind superficial or artificially imposed selves which people with a shared history and ancestry hold in common" (223). This first position essentialises cultural identity, viewing it as more about a recovery of the past, which when found will secure our sense of ourselves. Hall's second position reflects a more flexible idea of identity. Cultural identity, according to this view, is constantly transforming and changing over time. There are many differences that constitute what we are now since history has intervened.

...cultural identity in this second sense is a matter of becoming as well as of being. It belongs to the future as well as the past, it is not something that already exists... Cultural identities come 
from somewhere, have histories but like everything which is historical, they undergo constant transformation... its only from this second position that we can properly understand the traumatic character of the colonial experience (p225).

From Hall's essay we can see discussions of cultural identity as potentially split between two poles of essentialism and anti-essentialism. Putting Hall's work into conversation with Pacific Studies literature and drawing from indigenous epistemology, the Polynesian concept of vā, when used as a theoretical lens, can be a potential tool for navigating between these two poles. This will be elaborated in greater detail shortly, but first two additional terms for conceptualizing mixedness must be introduced and discussed.

\section{Hybridity and Interstitiality}

Another theory that is associated with people of mixed ethnic heritage that is relevant to this thesis is racial hybridity or hybridization. Hybridity was normally associated with race and in this sense relates to the fusing of two or more different cultures. Some postcolonial theorists discuss hybridity as the interactions between "colonisers" and "the colonised" and the dichotomous formation of these identities (Yazdiha, 2010; Hollinshead, 1998; Goldberg, 2005).

As literature analyses (Bhabha 1994; Wendt, 1996; Yazdiha 2010; Goldberg, 2005), historically the product created from the mixing of those who were the dominant race together with those who were seen as the inferior race, was believed to be a representation of impure blood, a dilution of purity and a loss of power for the dominant race. This was viewed as an abomination, particularly in US history (Yazdiha, 2010). This racism was used as a tool of power that created ambiguity, placelessness and exclusion of the "hybrid" (Yazdiha, 2010). Due to the thought that hybrids diluted purity and power, hybridity was seen as a threat and it was feared. In order to prevent it from occurring, laws and policies was introduced to keep races separate (Goldberg, 2005). Segregation was about keeping dominant social groups in power and to keep their race "pure." 
In many colonised contexts, hybridity was also used as a tool to create a "new race". Colonisers would interbreed with the colonised or indigenous people to create hybrids who, in a hierarchical system, were situated above the indigenous population but below European colonials. This was to ensure that if the colonisers ever wished to return to their homeland, they had installed a new race of oppressors, who would have fairer skin and more prestige due to their dominant heritage and could exert power over the indigenous (Goldberg, 2005).

Pacific scholar Albert Wendt argues against the term "hybrid" and "hybridity" in his 1996 essay "Tatauing the Postcolonial." As discussed, the term "hybrid" is one that signifies racial blending of two (or more) originally "pure" forms, suggesting that cultural/racial classifications of purity still exist somewhere up the chain. Wendt finds this damaging to the Pacific psyche in that it implies the person of mixed heritage is somehow "half-casted".

However, in the postcolonial era and with populations of those with mixed ethnicities increasing, we might question whether the same negative connotations still shape understandings of "hybrids"? Though labels still persist, classifications of pure and impure do not carry the same power of representation as they once did historically. The introduction of census collection processes that recognise mixed ancestry is one example of how mixed people have been given a "place" - at least in official population statistics (Yazdiha, 2010). Something that was culturally and politically shunned is now (in some circles) fashionably embraced and welcomed. An increase of hybridity indicates an increase in social diversification and this has been argued to be extremely useful in our societies today. Government systems and organisations in particular now recognise that people with different cultures, beliefs, values, and experiences add cognitive diversity to organisations and generate a broader range of useful perspectives and ideas (Deloitte, 2011). This is important for organisations to ensure the relevance and approachability of the services they may offer (BNZ, 2014; Deloitte, 2011). From this perspective, multi-ethnic individuals reflect the multicultural societies that we now live in. 
Torika Bolatagici, who is of Fijian and white Australian ancestry, uses the theory of hybridity in her journal article "Claiming the (N)either/(N)or of 'Third Space': (re)presenting hybrid identity and the embodiment of mixed race" (2004). She says,

Giving up the desire for a pure origin, hybridity retains a sense of difference and tension between two cultures, but without assuming hierarchy. It is not just new identity but a new form of identity... (Sakamoto, 1996: 115-116, cited in Bolatagici, 2004: 77).

In some cases, rather than having hybridity being viewed as destructive, it can also present an understanding of coexistence. The concepts of hybridity and, as will be discussed shortly, vā, can both be used to describe a place where the fusing of multiple ethnicities and cultures can coexist, where cultural and racial boundaries can be deconstructed. Hybridity particularly gives access to the movement between different cultural arenas (Yazdiha, 2010).

Another relevant way of thinking about 'spaces between' that can be spaces to claim and form identities is interstitiality. In his 2009 essay "Working in the space between: Pacific artists in Aotearoa/New Zealand", Graeme Whimp offers a brief survey of several New Zealand-based Pacific artists and also explores whether they have been influenced by essentialist and pluralist impulses. He attempts to locate a cultural space in which these artists have been able to express their identities. In this essay he rejects vā as a conceptual term for characterising such a space because he believes that it does not clearly represent the Pacific artists' identities and the space in which they inhabit. He outlines, "and not even vā" is the most appropriate conceptual term, "because it is not so much a separation that connects as a space isolated from the other competing but inaccessible communities, one in which artistic identity can be developed and maintained" (19). Instead of vā, Whimp settles on interstitiality as more appropriate to describe this space.

Bhabha, in turn, extended interstitiality to "the articulation of cultural differences" $(1994,1)$. Bhabha continued: “These 'in- 
between' spaces provide the terrain for elaborating The Space Between [20] strategies of selfhood-singular or communalthat initiate new signs of identity, and innovative sites of collaboration, and contestation, in the act of defining the idea of society itself" (1994, 1-2). (cited in Whimp, 2009:19-20)

Although Whimp discounted the concept of vā as not relevant for exploring the 'space between' for artists, I believe that vā is relevant for an in-depth analysis of the artists at the centre of this thesis. The following section makes the case for the usefulness of vā as a conceptual tool for this research.

\section{Vā}

The Samoan concept of $v \bar{a}$ has corollaries in a range of central and eastern Polynesian languages, and is increasingly used in Pacific scholars' work. In his essay "Tatauing the Post-colonial Body," Albert Wendt (1996) describes the concept:

$V \bar{a}$ is the space between, the betweenness, not empty space, not space that separates, but space that relates, that holds separate entities and things together in the unity-that-is-all, the space that is context, giving meaning to things. The meanings change as the relationships and the context change. A well-known Samoan expression is 'Ia teu le vā'. Cherish/nurse/care for the vā, the relationships. This is crucial in communal cultures that value group, unity, more than individualism; who perceive the individual person/creature/thing in terms of group, in terms of vā, relationships (Wendt, 1996: 402).

Wendt argues that the "space between" is neither vacant space, nor a space that needs filling or closing, but it is a place where relationships are formed and taken care of, which on many occasions requires effort from both, or multiple, parties involved. The space between is a place of different as well as shared identities, a place where there are differences as well as similarities between cultures, and families and traditions are acknowledged. This relational space is interactive and 
draws people closer together when time and effort is put into nurturing and maintaining it.

Samoan geographer Sa'iliemanu Lilomaiava-Doktor (2009) also discusses vā characteristics in her work. She argues that the vā is embodied in understandings of proper and improper behaviors, such as those related to seating/sleeping arrangements, the use of language in private and public places, and also how food is divided and distributed. The space in-between can also relate to our relationships with our families, which is something that is regarded as extremely significant in Samoan cultures. In her essay, Lilomaiava-Doktor discusses the important dimensions that are part of fa'asamoa or the Samoan way of life. These include 'äiga (kin group), conceived of as tino e tasi (one body) and toto e tasi (one blood), and principles of tautua (service), fa'alavelave (obligations), alofa (love, compassion) and fa'aaloalo (respect) in kinship relationships (2009: 7). As part of Samoan culture, Samoans are relational beings: they do not exist as individuals - the culture is communally based (Tamasese et al, 2005; Tui Atua, 2003). Samoans understand the concept of the vā as the space between which refers specifically to the social aspects of relationships that are expressed between 'aiga. However it can be extended to go beyond 'aiga relationships: "Chief-orator, sister-brother, clergy-village, husbandwife, parents-children, people-environment, or God-people respect relationships are all tangible examples of vā" (Lilomaiava-Doktor, 2009:14)

As Lilomaiava-Doktor proposes in her essay, Samoans continuously refer back to the vā when explaining the concept malaga-which in Samoan means movement back and forth and is also the polite word for both alu (go) and sau (come); it implies both visiting and returning. So when discussing malaga it doesn't refer to just leaving Samoa but also returning; traveling back and forth to attend or contribute to fa'alavelave (family obligations). Originally travel was undertaken and gifts were provided for things such as births, marriages and funerals, but the scope has now broadened with contemporary movements for the purpose of education, health, and economic opportunities (2009: 10). Themes that were presented in Lilomaiava-Doktor's essay (2009) around malaga were not just 
stories of the pursuit of wealth to climb the economic ladder for one's own personal advantage in life, but for one's family and to support others to nurture those relationships - the personal narratives drawn upon in the essay evoke vā as linking personal identity and self-esteem to people's relationships to others. Lilomaiava-Doktor's findings and discussions demonstrate how vā, malaga and fa'alavelave work hand in hand: to maintain the vā, to support the relationships between kin members at home and abroad as well as those that remain in the islands to take care of the land, it seems that there is a need to engage in fa'alavelave: "one may be part of a kindred, but if not maintained and expressed in tautua (service) and vā fealoa'i (balanced social space), the 'âiga loses legitimacy" (2009:8). I agree that groups and individuals have a responsibility to show respect to each other to form balance within the community, which is reflected in our episteme. Lilomaiava-Doktor identifies the role that Samoan epistemology has in understanding the vā, "Epistemologically, vā is encoded with respect, service, and hospitality in maintaining and retaining 'āiga [family] status and a socially well-located family" (2009:14).

Wendt's 1996 articulation of the concept of vā has been adopted by many scholars, particularly in the health sector. The vā is space between places, people and the environment that provides context and symbolises relationships. Wendt recognizes the importance of the vā and social space. Lilomaiava-Doktor (2009) suggests this is because the Samoan concept of self is a concept that is holisticcommunal-based rather than focused on the individual. This Samoan concept of self is closely associated with vā.

Working in the health sector in New Zealand, Kiwi Tamasese, Carmel Peteru, Charles Waldegrave and Allister Bush worked together to develop a culturally appropriate research method to investigate Samoan perspectives on mental health. In their study they discuss the vā and the concept of self, understanding these as important concepts to better understand their participants. The focus groups expressed their viewpoints on the causes of mental ill health. These examples included forbidden or sacred relationships, pressures in New Zealand such as the inability to reach family obligations, and also the difficulties of 
adjusting to a multicultural society (particularly for young people). Tamasese et al succintly capture what the participants discussed. "Several major themes emerged from this part of the focus group discussions. Firstly, participants maintained that mental illness was more likely to occur when extended family relationships were disrupted and traditional relational arrangements weakened. Secondly, conflicting values between Samoan culture and the dominant Palagi (European) culture in New Zealand were viewed as a significant ongoing stressor" (Tamasese et al, 2005:304).

The participants in the study stated that the nature of the Samoan person is that of a relational being, comprising spiritual, mental and physical elements that cannot be separated. The authors also argue that Samoans are widely communal, making it difficult to remove the Samoan from the collective context: "This self could not be separated from the 'vā' or relational space that occurs between an individual and parents, sibling, grandparents, aunts, uncles and other extended family and community members" (Tamasese et al, 2005: 303). Participants in this study stated that one cannot prosper on their own; the Samoan belief is that when in need you look to each other (Tamasese et al, 2005).

Also writing on the topic of mental health, Fuimaono Karl Pulotu-Endemann created the Fonofale model in 1984. Refined since then, the Fonofale model is a Pacific Island framework of health for use in the New Zealand context. This model encapsulates the needs of Pacific people to maintain their personal wellbeing and mental health. Utilising the metaphor of the Samoan fale or house was a way to incorporate and depict a Pacific understanding of what was important to Pacific cultural groups. In the model, the foundation or floor symbolises family, a fundamental component of all Pacific cultures (PulotuEndemann, 2001). The roof symbolises culture. The four posts that connect the floor with the roof symbolise spiritual, physical, mental, and other influences (the 'other' category includes such things as sexuality and gender orientation). This fale model is further encapsulated in a circle of time, environment and context (see Pulotu-Endemann, 2001: Fonofale Model of Health). While PulotuEndemann does not name vā explicitly his model is helpful for visualising the 
many relationships that exist within the vā: vā can be understood as the basis that holds the house together, and a damage to one part, damages the vā.

Being part of a collective can involve responsibilities, obligations and expectations. If not fulfulled - the inverse of teu le vā-such obligations can become a stressor for the individual, leading to mental health issues. Therefore, a sense of tauhi vā/teu le vā also needs to be negotiated by an individual; maintaining good relationships ensures that there's strength to face any disruptions in other aspects of life. This point is important in the discussion of Pacific mixedness because of people's desire to categorise and organise. Someone who is of mixed descent may seem harder to place than others who are mono-ethnic, and this can cause feelings of "otherness" or feeling different in a wider community that can lead to conflicting feelings within. This individual nurturing can also enhance the social relationships we have because of the balance and harmony.

The concept of vä makes sense within a view of society that emphasises relationships. To understand the importance of vä,one must view relationships as the most influential dynamic in shaping both individual identity and the nature of the social world. Therefore, it is within the context of relationship that self identity is formed and is continually affected. In addition, it is the nature of all of our interactions with others (on a much larger scale, the culmination of all relationships) that shapes the very nature of our society, either harmonious, indifferent or in conflict. (Mila-Schaaf, 2006: 9-10)

In the digital age, the ways we negotiate and maintain interpersonal relationships are not always the same as in the past. In Cresantia Frances Koya Vaka'uta's conference paper, “Cyberspace, place, identity \& relationships: Are we digitizing the Vā?" (2012), she references how in this media driven era, it is becoming increasingly popular and convenient to communicate through cyberspace. She discusses how "e-relationships" are nurtured, valued and cared 
for through communications on the internet (2012:2). She notes the sparseness of research available that critiques cyberspace from an indigenous perspective. Before the advent of telecommunications, the process to teu le vā/tauhi vā was maintained in physical place and time; now it also takes place in "cyber-space and cyber-time" (Koya Vaka'uta, 2012: 3). Both ways still occur but respected "cultural norms" are now being re-negotiated. This is particularly evident through social media sites, which are common forms of communication for today's youth,

nightclub scenes, romantic relationships, cuss words, and agespecific discussions on fashion, relationships and other interest issues are often commonplace in the middle generation category of 18 - 35. It is peculiar that none of first generation members (aged 37 -50) comment or rebuke the younger group. Can we interpret this silence as acceptance of new terms of engagement online?; or a silent disapproval? ... Such 'sharing' of these topics and issues is inappropriate in real-time cultural family relationships, but cyber-space enables a differential set of rules of interaction. (Koya Vaka'uta, 2012: 4, boldface in original).

This quote references what can commonly be shared through the updated statuses and comment boxes on social media sites such as Facebook. These social media forums can be useful for maintaining relationships with those that are dislocated from physical place; however they can also be dangerous platforms where once-accepted practices to teu le vā are sadly not followed. This point will be taken up further in subsequent chapters.

By understanding vä as a system requiring harmony, balance, reciprocity and mutual respect and relationship, one may ask the person they are working with, in what ways their relationships are consistent with this 'ideal system'. How healthy is the vä? Are relation- ships configured in a positive manner? A focus on vä, and understanding the nature of 
relationships in causing anxiety, illness, depression or crisis in a person's life is consistent with the traditional healing approach used for centuries in the Pacific. (Mila-Schaaf, 2006: 12)

Vā has been exceptionally useful for thinking through Pacific-centric approaches to health services in New Zealand. This concept has also found relevance in the realm of architecture. Albert Refiti describes how vā has been useful for understanding the heritage of Polynesian architecture in New Zealand in that it encapsulates ideas of good or ideal spatial ordering.

The vā is a spatial ordering concept that exists between things and administers a code of a good (ideal) behaviour, an invisible language that enables space and things to be configured in a positive manner. It governed traditional aesthetic appreciation in Samoa, Tonga, Niue, the Cook Islands and Aotearoa from oratory to boat-building, tattooing to the fabrication of building and space. In architecture, the space of the malae (Samoa, Tonga, Niue) or marae (Cook Islands Māori) best represented the spatial make-up of the vā. (Refiti, 2002: 209)

Refiti acknowledges how certain customary structures were designed with social relationships in mind. He refers to this as architecture in action (2002: 210). Refiti uses the example of the malae, the open ceremonial ground that serves as the venue for important meetings and ceremonies in Samoa, with high chiefs from each family taking their proper order on the malae in respect to their vā relationships and hierarchy of their status in the village fono/council (Refiti, 2002).

While much of the writing on the concept of vā discusses it in Samoan contexts, literature on cognate concepts exists for other Polynesian contexts. Tongan scholar Konai Helu Thaman (2004) describes the vā as being a "Proto-polynesian notion of an interval of space and time, that is "commonly found in Pacific Island 
countries such as Tonga, Samoa, Uvea, French Polynesia, Cook Islands, Niue, Tokelau, and among the indigenous people of New Zealand and Hawaii” (Thaman, 2008:463). She further explains that "pan-Polynesian notions of vaa metaphorical spaces between and among people and groups and inter-group relationships and responsibilities (2008: 470).

Thaman also defines the Tongan concept of tauhi vaha'a as "to look after or protect the spaces between two or more persons or groups who are related to each other in some way" (2008: 464) This is similar to the Samoan concept teu le vā, which conceptualises the actions of nurturing and looking after relational space (Anae 2010). Thaman says that because of Pacific peoples' communal characteristics, the spaces between people, as well as between people and their environment, must be nurtured and protected. While Thaman details specific ways in which tauhi vaha'a is understood and enacted in Tongan society, she suggests that the concept of vā is more generalisable and can be usefully applied outside of Tongan contexts: "perhaps vaa can be globalized and taught in schools since acknowledging and nurturing it through education will go a long way towards improved intercultural understanding among people and communities" (2008: 470). Tèvita 0 Ka'ili, who is also of Tongan descent, writes about his practices of tauhi vā while he was living in Maui, Hawai'i, where he encountered many other Tongan people. The vā in the interpersonal social context refers to both social relations and space; to Tongans, human relationships are both socially and spatially constituted. Vā then also connects individuals and groups to one another. Therefore when Ka'ili would encounter other Tongans they would discuss their genealogical ties to their kin and homeland, establishing relationships between each other. He states that "the practice of tauhi vā requires a lot of time, energy, and resources" (2005:101). In another example of a Polynesian cognate, Hawaiian scholar Lilikālā Kame'eleihiwa references the Hawaiian concept of wā in her history monograph Native Land and Foreign Desires (1992), translating the term as conceptualising both time and space (Kame'eleihiwa, 1992: 22-23). 
Anae uses the concept of vā as part of a strategy of forming respectful relationships in the education sphere in New Zealand, specifically drawing from the Samoan remonstration to teu le vā, meaning to value, cherish, nurture and take care of the vā-the relationships. The development of this concept in the education system was important so that teachers and researchers had greater competency in the nuances of Samoan culture, which therefore enhanced the relationships between students, teachers and researchers (Anae, 2010). Lilomaiava-Doktor interviewed Aumua Mata'itusi Simanu, Professor of Samoan Studies at the University of Hawai'i, Mānoa, who notes why this cultural understanding is important,

Vā is the most significant concept to understand the complexity of Samoan social interactions between people, church, and the environment. It underpins all epistemologies of participation, obligation, and reciprocation that guide our interactions and continue even as Samoans move abroad. Performances of social responsibilities and obligations prescribed in Vā rest on the knowledge of social and genealogical connections that 'aiga members possess (Aumua Mata'itusi Simanu, 2006, quoted in Lilomaiava- Doktor, 2009: 13-14).

Melani Anae relates the vā concept to the "physical, spiritual, cultural, social, psychological and tapu spaces of human relationships" (Anae, 2010: 2), and suggests it is especially suitable for thinking through complex relationships in New Zealand Pacific communities marked by inter- and intra-ethnic diversity, including increasing rates of mixed ancestry.

Acknowledging the variety of ways that this theory of space and socio-spatial relationship has been used by other scholars and artists, this essay hopes to use the concept of the vā and this relational space/liminal space and apply it to those that have mixed Pacific heritages, relating it to how relationships, cultural understanding and difference is acknowledged and respected in "the space between." As already mentioned in the introduction, some Pacific artists have stated they feel a responsibility to their Pacific communities by portraying 
recognisably Pacific attributes in their artwork. This is directly associated with the concept vā as they try to respect the relationship between their culture, cultural communities and how this is represented in their artwork.

Returning to a key theorist in the field of Cultural studies, Stuart Hall believes that cultural identity is not static, but is a production that is always in process and never complete. Recalling the two positions on cultural identity he outlines, although they seem diametrically opposed there is a possibility to use indigenous Pacific concepts such as vā to navigate between the poles of essentialism and anti-essentialism. This can be done through the understanding of the Samoan concept teu le vā and the Tongan concept tauhi vā, which both mean to take care of, to tend or nurture the space between. Tauhi vā and teu le vā might appear to operate according to an essentialist logic—signaling a "one shared culture" in which Tongans or Samoans are all related-but Ka'ili's focus on the work involved to "tauhi vā" and Mata'itusi Simanu's emphasis on the "performance of social responsibilities and obligations" simultaneously signal that this shared culture is a constant production and it requires engagement to maintain and nurture the relationships in the process of being made. This thesis follows Thaman's lead in highlighting commonalities in pan-Polynesian understandings of vā and the concept's applicability to broader contexts; it draws on both Samoan scholarship on teu le va and Tongan scholarship on tauhi va to theorize, more generally, the relationships of Pacific artists of mixeddescent in New Zealand, without intending to disregard the respective specificities of how these concepts are understood in Samoan and Tongan contexts.

The vā concept is particularly relevant for analysing and exploring the influences and work of the three chosen artists. Drawing on the concepts of tauhi vā and teu le vā, this thesis explores how these artists are actively articulating and maintaining their cultural connections and engagement with the various aspects of their multi-ethnic identities. Niki Hastings-McFall has directly used the term vā in artwork titles and exhibition materials. For example her 'Va-riant' series explores the liminal space that both separates and unites the different cultures 
that represent her make-up (Hastings-McFall 2013). Grace Taylor has also incorporated vā into her poetry. Featured in her published poetry book is the poem 'I am the Va', where, similar to Hastings-McFall, she explores her 'afakasi identity as being the space between, where she is not fully one culture or another.

I am the va

so cut me up

scatter me among yourselves

and taste the bitter sweetness

of the space between

brown

and

white

(Taylor, 2013)

While Aaradhna does not engage the vā concept directly in her song titles or lyrics, the concept is particularly useful for exploring how she engages with both her Samoan and Indian cultures, as evidenced in the visual imagery of her music videos and how she describes her cultural mixedness in interview material. As will be discussed in Chapter 4, critical questions raised by Koya Vaka'uta (2012) regarding how vā is and isn't being maintained in cyberspace are also useful for exploring the impact of Aaradhna's experiences with social media on her life and work.

This chapter opened by contextualising the rising rates of populations of Pacific ancestry in New Zealand, exploring the phenomena of Pacific migration and diaspora. Movement from the Pacific islands to New Zealand has occurred for centuries; as Salesa (2003) highlights, travel and mobility_or as LilomaiavaDoktor (2009) specifies, malaga (movement back and forth) -is central to Samoan conceptions of their island homeland. Circular movement helped nurture and take care of the vā between the migrant generations and the ones that stayed in the islands. 
Due to the relationship instigated by New Zealand's former administration of Samoa, many Samoans have continued to disperse and settle in New Zealand, where rates of intermarriage between them and other ethnic groups became significant. This chapter therefore explored the mixed Pacific identities that have been constructed in New Zealand due to this movement and relocation of Pacific migrants, and mixing with other ethnic groups. This thesis draws on both Cultural Studies and Pacific Studies to think about and conceptualise the nuances of identity associated with Pacific mixedness. Hall explores two very polar ways of viewing identity, one definition being a revival of the past in terms of cultural identity - an essentialist view - and the other believing that cultural identity is not static, that it changes and is much more fluid, particularly with time and historical intervention, which is a very anti-essentialist way of viewing cultural identity. As this chapter concludes, vā provides a relevant and useful theoretical framework that helps us navigate between these two opposing views. To teu le vā and tauhi vā means to nurture, value and take care for the vā, indicating that the relationship is a constant production. Drawing on the concepts and theoretical tools discussed in this chapter, this thesis will now explore how the three artists at the center of this thesis, Niki Hastings-McFall, Grace Taylor, and Aaradhna Patel, explore their mixedness within their realm of creativity and selfexpression, and how they teu le vā with the various aspects constituting their mixed selves. 


\section{Chapter Two: Niki Hastings-McFall}

\section{About the artist}

Niki Hastings-McFall was born and raised by her British grandparents in Titirangi, West Auckland. In interviews with Sarah Robins (2008), and myself, (2016), Hastings-McFall discussed her experiences growing up. In both interviews Hastings-McFall describes her grandmother as being very British and this was very influential on how Hastings-McFall was raised, which was in a very British fashion, right down to the clothes she wore, the attitude she was brought up to have, and the environment that she lived in. She explains that she was not often exposed to any Pacific people while growing up, "Titirangi was really pakeha there was hardly any Māori out there let alone Samoans," (Robins 2008: NP). She lived in Titirangi right up to the age of seventeen, and then left to live in a hostel when she started university. (Hastings-McFall, interview material, 2016).

Hastings-McFall discusses further with Robins important milestones in her life. She was raised believing her biological mother was her sister and her grandparents were her biological birth parents. However, at the age of 10 years old she discovered the truth about her biological mother and the fact she was adopted by her grandparents. Being in admiration of her "sister," she was rather pleased about the news. If that was not enough of a revelation, she was also informed that she had a Samoan father named James McFall. When she misbehaved her grandmother would often spit at her "that's the Samoan coming out of you," (Robins 2008: NP) even before she knew she was Samoan.

Later on in her life she traveled Europe and, upon her return to New Zealand, while between jobs and at Work and Income New Zealand, she came across a stapled-together pamphlet about a jewellery course. It was at this point that she thought she could give it a try and that's how she decided to pursue a course in jewellery at Manukau Institute of Technology's School of Visual Arts. This was something she thoroughly enjoyed and it became a useful tool in her career path. 
Another major milestone in Hasting-McFall's life occurred in 1992 when she met her father James McFall, who at the time was living at his mother's house because he was extremely ill. Hastings-McFall describes what this encounter was like: when she came to the house a woman (her aunty) opened the door and Hastings-McFall was startled by the initial appearance of this woman: she described her to be big and tall with fuzzy grey hair, a deep growly voice, and beautiful big green eyes, wearing a mumu dress, totally different to anyone she knew. In the years to follow Hastings-McFall grew to adore her aunty and even made her first trip to Samoa where her Aunty celebrated her $70^{\text {th }}$ birthday. On that initial day that she met her aunty she also met her grandmother as well. Despite the slight cultural shock, she was swept with an amazing sense of identification. In an interview with the artist (2016), she recalls this encounter,

I met my grandmother and I walked into the lounge and saw a whole lot of, like, football photos and family photos, and they all had lei around them and I just went - wow! That's where that comes from. Because I had always done that ever since I was a kid, with pictures or mirrors or whatever, I always hung long necklaces round them, I use to make little shrines and stuff - I don't know - probably a very human thing to do but it was just this amazing sense of recognition... And that's basically what started me off; I mean I was doing jewellery anyway but that had a huge influence on choosing the form of the lei as one of my primary formats for work. (Hastings-McFall, 2016)

Unfortunately her father, being very ill, passed away that same year. Despite the short encounter, this meeting and the subsequent relationship with her Samoan family has had a profound effect on Hastings-McFall's life and work, and since then, her work has been increasingly driven by research into her Pacific Island heritage (Mallon \& Pereira, 2002; Robins 2008)

\section{Visual art and artists}


Sean Mallon and Pandora Fulimalo Pereira, authors and co-contributors to a range of texts on Pacific arts and artists in New Zealand (1997; 2002), discuss the rising recognition of Pacific peoples' achievements in the arts over the past four decades here in New Zealand. In Mallon's article "The Art of inbetweenness: Reflecting on Pacific Art Practice in New Zealand," (2004) he indicates that by discussing the 'arts' he is speaking in the broadest sense, encompassing the artistic infrastructure through sports, theatre, fashion, music, dance, design, media and visual art. Whether it is kicking a ball across a rugby field, transitioning from the stage to cinema, or creating a beautiful motifinspired painting, Pacific people have been contributing to the arts and community with a range of skills, talent, experience and creativity, and with a unique Pacific style that is in high demand both locally and internationally (Mallon, 2004; see also Mallon \& Pereira, 2002).

Art is a medium that allows expression of tradition, cultural values and selfidentity (Mallon, 2004). From the blooming population of early Pacific migrants in the 1950 s to 1970 s came the emergence of the 'New Zealand-born' population. New Zealand-based art historian Karen Stevenson (2008) has discussed the 1990s as the time that "Pacific Art" — specifically visual art—became a vibrant, flourishing style in New Zealand. She suggests that labeling the movement "Pacific" indicates that ethnicity played a key role in recognising the artists involved with this contemporary practice, and that ethnicity ties closely with identity. Stevenson argues that many of those who are classified by others as Pacific artists abhor the stereotype that this term evokes; she notes, "frequently it is this stereotype or, more specifically, the renegotiation or destruction of it that plays a large role in Pacific art practice" (2008: 19). This is not unique to New Zealand: Stevenson then discusses that issues of identity and needing to find an ethnic voice was also very much part of a global academic and artistic debate in the 1970s, particularly in conversations around indigenous art (Stevenson, 2008: 19). Peter Brunt discusses how these imperatives had much to do with de-colonisation: "the revival of customary culture was a powerful political force by the 1970 s, and many contemporary artists began to turn to it as 
a source of anti-colonial resistance and alternative value" (Brunt et al, 2012: 374). The debate has forced the matter of identity, which as Nicholas Thomas has noted, is above all about belonging to a culture, "it ain't where you're at, its where you're from" (Thomas, 1996: 340 cit. Stevenson, 2008). This concept of identity is elemental to the work of Pacific artists and as a consequence, identity and politics often become embroiled (Stevenson, 2008).

Ethnic identity has been a common artistic focus in New Zealand in the 1990's. Stevenson (2008) offers several different reasons for this. She suggests that, most commonly for artists, it was a desire to draw on their cultural heritage, to display their own opinions on the politics of the post-colonial age, and to draw on their placement and experience here in New Zealand, building on their ambivalent relationship with Māori and position of being a minority within New Zealand. Mallon (2004) describes this theme of art as an expression that derives from feelings of loss of culture, homelessness and the constant uncertainty of identity or belonging. Literature on Pacific art and artists in New Zealand notes, however, that expressions of identity can sometimes be overused or typically expected of Pacific artists (Mallon \& Pereira, 1997; Mallon, 2004). Stevenson (2002) argues that sometimes positioning oneself as a Pacific artist can make for a difficult situation as it provides a responsibility. Often this expectation of responsibility is placed on artists from those within their own culture; they become the culture's representative and as such they are expected to maintain an allegiance and relationship with "the community." This can sometimes produce pressure on artists, especially when dealing with cultural critics from their own Pacific ethnic group, this can be closely linked to the discussion in Chapter One around notions of wellbeing and mental health, (Tamasese et al, 2005; Pulotu-Endemann, 2001). Some artists aren't bothered by this. For example, John Ioane says, "I don't feel like I have to be culturally safe or culturally sensitive, that's like a border to me. Political correctness is bull" (Mallon \& Pereira, 1997:39).

In New Zealand, there are some prominent Pacific artists in our communities that have achieved critical and commercial success in the arts industry. Their 
exposure to two or more cultures is a key commonality and influence for these artists' work (Stevenson, 2009; Mallon \& Pereira, 1997, 2002, Tiatia, 1998). In conversations illustrated in Speaking in Colour, edited by Mallon and Pereira (1997), we discover stories of prominent Pacific artists in New Zealand. One such New Zealand artist is John Pule, who is of Niuean descent. Literature shows that Pule draws inspiration from both his Niuean heritage and the urban New Zealand culture, but Pule himself says that he often doesn't feel comfortable with either group (Stevenson, 2008, Mallon \& Pereira, 1997, 2002).

Intellectually and emotionally I relate to both New Zealand and Niue but I don't feel too comfortable in either. I feel an outsider and am often treated like one in Eurocentric New Zealand and called a 'goagoa fia palagi' in Niue, which means 'a dumb wannabe whiteman.' I slip between acceptable stereotypes in both places because traditional categories cannot organize my identity. I am nearly everybody's 'other' (Whimp, 2009: 13).

Pule's comments here are reminiscent of the poem from Melani Anae cited earlier, illustrating how issues of in-betweenness are as influential for Pacific artists as they are for other Pacific people in New Zealand. As seen from this quote from Pule, Pacific artists (even if not of mixed parentage) are "hybrids" in the sense of being the products of the influence of multiple cultures.

There are many other Pacific artists living in New Zealand who do similar work to Fatu Feu'u and John Pule, but I would now like to draw specifically on those artists growing up in New Zealand that are of multiple ethnicities. The small existing body of literature on Pacific art and artists in New Zealand includes examination of how artists explore their mixed heritage, fusing and blending cultures together. These elements help build their artistic practices and feed their creativity, (Mallon, 2004; Mallon \& Pereira, 1997; 2002; Stevenson, 2002; Whimp, 2009; Brunt et al, 2012). For example, Michel Tuffery is of Rarotongan, Samoan, Tahitian, and New Zealand Pākeha descent. In their 1997 publication, Mallon and Pereira noted that Tuffery largely draws from his Samoan 
background in his work. However, Tuffery's more recent projects display a broader range of Pacific historical influences (Tuffery, 2013). Michel Tuffery has said, "If you live here, you've got no identity" (Stevenson, 2002:80) because artists that are born and raised in New Zealand often don't belong to the islands that they reference. As Stevenson notes, "Pacific artists draw upon the stereotypes - on tapa, tiki, and tatau - to create both a relationship to the islands as well as a home. Owning and critiquing the myth establishes them as urban Polynesian. The desire to identify with the islands when they do not belong creates inconsistencies and contradictions that translate into metaphors in their arts practice" (Stevenson, 2002: 80).

A prominent female artist, Ani O'Neill, is of Cook Island and European descent. As literature suggests, O'Neill draws heavily from her Rarotongan background as well as acknowledging her urban status (Asian Society, 2004; Cochrane, 2000; Stevenson, 2008; Whimp, 2009). As explained on the website for Pasifika Styles, a 2008 exhibition and festival of contemporary Pacific art at the Museum of Archaeology and Anthropology at the University of Cambridge, O'Neill creates objects and installations using traditional weaving and tivaevae skills that her Cook Island grandmother taught her (Pasifika Styles 2008). She uses these skills to create installation work such as crocheted wool circles for her Cottage industry series (Walrond 2015). Ani O'Neill's use of cultural craft skills exemplify how Stevenson's quote about artists being established as "urban Polynesians" in New Zealand, who are translating metaphors in their own art.

Similar themes are expressed through the work of other New Zealand Pacific visual artists of mixed ethnicities, including Lyle Penisula (Samoan/European), Pauline Hoeft-Cocker (Tongan/Cook Island), Shigeyuki Kihara (Samoan/Japanese), Lily Laita (Māori/Samoan) and of-course Niki HastingsMcfall (European/Samoan).

\section{Medium (Mixed-media art)}


Niki Hastings-McFall's art spans jewellery, mixed-media, sculpture, installations and assemblage and for this she uses an eclectic range of materials and forms for her pieces of work. She uses the materials that are accessible to her-items that are second hand and/or what most people may consider to be rubbish or recyclable. Some of these objects may have their own special symbolism or story prior to Hastings-McFall's ownership. She gives new life to the items adding more layers and new meaning through their juxtaposition,

It's also important to me where my objects come from. I have my own stories to add to the materials souvenired from a wide variety of sources. These objects become talismans and touchstones for memory. Some I have had for forty years or more, some are picked up off the roadside, some are scavenged from junk shops, some 'won' on Trade Me and some are gifted (Danse: Hastings-McFall, 2011: 3-4).

For Hastings-McFall, there is a power in objects: they can have their own stories to tell, they can create and share relationships, or bring people closer together. Hastings-McFall has a talent for giving new life to everyday humble objects and she receives great pleasure from acquiring stuff that others would normally throw away (Danse: Niki Hastings-McFall, 2011). Hastings-McFall's art practices express an appreciation for her environment through her upcycling and her love of thrift.

Before migration to New Zealand, most Pacific people obtained ancestral skills such as weaving and creating decorative items using natural fibres and materials such as ivory, tortoise shell and horn. Pacific people found it difficult to source the same materials in New Zealand and it was also expensive to send these from the islands, therefore they looked for alternatives materials. Plastic is sturdy and easy to come by so by utilizing the skills they brought to New Zealand they were able to use materials around them that are easily accessible and reasonably priced to create everyday items, items for special occasions, ceremonies and 
events. Plastic is now a material of choice in its own right (Museum of New Zealand Te Papa Tongarewa, 2011).

These techniques are still able to thrive because of the adaptation and innovation that the Pacific community has shown. For example, in interview material Hastings-McFall describes a pandanus fan that she has possession of. Woven through the pleats of the fan is the foil from chip packets, and when the fan is used for practical use in the sun, those weaves of foil reflect and sparkle against the light. In a Tautai²-supported interview available on YouTube, HastingsMcFall talks about this particular pandanus fan: "from something that was just a piece of rubbish that probably 99.9 times out of a 100 would end up in the bin and someone's made this object that's really beautiful... a lot of that feeds into what I do now, its really important" (Hastings-McFall, 2011:1.39-1.59). Simple items with such innovation in the design are the types of work that influence Hastings-McFall's practice. Too much sushi lei (2000) is a direct example of Hastings-McFall creating an artistic piece out of recycled items. It's made from the small plastic fish-shaped soy-sauce bottles that have been joined together with a sterling silver ring to create a star design, (appendix A: figure 1).

Hastings-McFall is firmly situated in the urban lifestyle she inhabits while not trying to revitalise island traditions. Hastings-McFall often explores the urban contemporary and the ancient material culture of the Pacific in her work, as highlighted by Stevenson this demonstrates "great wit and desire" (Stevenson, 2004:124) to draw on Hastings-McFalls cultural heritage.

\section{Themes}

Hastings-McFall's upbringing, life events, education and personal experiences have continued to inform her art practice. She creates work that specifically relates to hybridisation, combining urban textures that convey a specific Pacific message, critique and expression (Kedgley, 2013). She often plays with the

2 Tautai Pacific Arts Trust is an organisation dedicated to the development and ongoing support of Pacific arts and artists. 
contrast of Western/European and Pacific or light and dark in her art. Her work to date indicates a particular interest in the topics of post colonial history in the Pacific, Christianity, love, loss and mortality. These topics of interest became some of the themes present in her art.

Early on in Hastings-McFall's artistic practise, she began to research Pacific material culture because of her interest in jewellery and first-contact history, this was of particular interest to her because it resembled how she felt - sort of like someone travelling out at sea for months to come to this foreign land, and she wanted to know everything about it. Of course this had an effect on her work and because she was studying jewellery, she ended up looking specifically at Pacific forms of body adornment and from then narrowed it down to making lei and breastplates (Hastings-McFall, interview material in Pasifika Styles, accessed 2013).

The narrative contained within an object has always intrigued me - how an inanimate object can record and encode so much emotion, history, and information. I think it is largely the scale of jewellery that allows this to happen - in general, small, wearable, personal and portable (Danse: Niki Hastings-McFall, 2011: 6).

From this initial interest and passion in jewellery-making, Hastings-McFall then grew to generate relatively larger works, which provided her with a platform to develop more sculptural forms and designs. Though her work has evolved away from jewellery over the years, jewellery-making has still informed various aspects of her general practise, her techniques and materials that she uses.

In interview material, Hastings-McFall often indicates a reflexivity and awareness about her own engagements with 'Pacific' art. She acknowledges how fashionable contemporary Pacific art practise had become in the 1990s. This is something Hastings-McFall describes with sarcasm in her interview with Robins as a Pacific revival/ renaissance period where Pacific people were less seen as 'bungas' and 'stupid islanders' and rather as wonderful people with a beautiful 
culture. Hastings-McFall explains that she didn't want to jump on the bandwagon and be one of the many pākeha who just copied tapa cloth patterns. She describes resisting this for about a year, but with continued researching she ended up giving in, thinking she would get it out of her system, (Robins, 2008). In fact she became inspired by sitting and staring at tapa-cloth on the wall and how it became almost hypnotic, completely captivating and mesmerising staring and following the different and yet repetitive patterns - this became inspiration for her that she then took and used in many of her art pieces - particularly the wall designs used with road sign-vinyl. Her Urban Navigator series (2001) is made of large-scale reflective road-sign vinyl and powder-coated aluminium.

The Urban Navigator series represents Polynesian navigation both in the past and present. Hastings-McFall uses a lot of chevron patterns, which resemble mountain ranges and are also seen present in tapa cloth, tatau and carving patterns. The designs present in these forms such as tatau and carving often reference elements in the natural environment. Reflective vinyl material similar to the one used in Dangerous Curves (Appendix A: Figure 2) is used today typically for roadside signage to offer those on the road direction safely and effectively to ones destination or to present warning signs. From interview material, Hasting-McFall expresses her thoughts about this piece and what themes she was exploring;

Basically just transposing what do we use for navigating - they use the stars and the sky and the sun, and the wave patterns and we use road signs and maps and things like that. So I started looking at road signs, and I liked the chevron pattern, I like the dangerous curves one because they were modulus. So you could make all sorts of different patterns with a bit of one work and also because they reflected the Tatau and the carving, weaving... all those patterns... which are so prevalent in the Pacific (Hastings-McFall, 2016). 
Hastings-McFall uses a lot of road-sign vinyl for different art pieces and the message can completely change depending on what symbol and shape it forms, for her Flock piece (see Appendix A, figure 3), which was also part of the Urban Navigation series, was exploring how we no longer travel in canoes, but we use aeroplanes, she was also thinking of the idea of birds, and light and how they travel and themes of migration and those association - hence why in this piece there are the aeroplanes positioned towards the centre and others away from the centre, implying those that are moving in and out of certain locations, another interesting manipulation of materials that Hastings-McFall creates.

Kedgley (2013) and Stevenson (2004) both identify the persistent use of the iconic floral lei in Hastings-McFall's work, which both authors read as an affirmation of her Pacific identity. They both also acknowledge how the lei has become a cultural stereotype due to its pervasive use in the tourist industry in the Pacific. Kedgley believes that Hastings-McFall has been seeking to reclaim the traditional significance of the lei, to reassert its status and prestige while simultaneously deconstructing the cliché of the lei as an exotic symbol of Polynesia.

Her Surburban lei and Urban lei series are made up of traditional lei-style necklaces that are made from an array of contemporary materials. In 2002 she created her Lightbox series of illuminated flower-covered light-boxes using disassembled synthetic floral lei. The light boxes also exemplify another recurring theme in Hastings-McFall's work-the use of light to symbolise divinity and faith (Danse: Niki Hastings-McFall, 2011).

As part of her In flyte exhibition held at Pātaka in 2013, Hastings-McFall created her Polynisation (appendix A: figure 5) series that featured domestic furniture completely covered with masses of artificial lei flowers. As part of her exhibition she had an audiovisual set up where she explained her inspiration for the series: while she was in Savai'i in Samoa she noticed a ferocious weed (likely mikania micrantha, known as fue saina in Samoan) that grew over everything in its path, taking the form of the object underneath. Hastings-McFall thought that this was 
quite an interesting metaphor for the relationships between Europeans and Pacific places and people. She took this idea and applied it to her work by dressing European furniture, very much like the furniture she had in her household in Titirangi, with a symbolic Pacific icon. Exploring aspects of Pacific history, particularly around European colonisation, Hasting-McFall plays with the term "colonised" in this piece. As discussed the lei flower is an iconic symbol for the Pacific, and as the name entails, has "polynised" the western European styled furniture. Like the unforgiving weed in Samoa, the lei flowers are enveloping and taking the shape of the furniture beneath it, which no longer resembles its original state, as if it has become hybrid. The European objects, may symbolise her European upbringing and foundations, which are now smothered with the knowledge she has gained about her Samoan culture and Pacific history. The hybridity of herself is shown in this piece.

\section{Vā}

Senior Pacific curator Sean Mallon explores how contemporary artists in New Zealand often fall between the popular and widely used dichotomies of art/craft, local/exotic, traditional/modern and New Zealand/Pacific. Mallon (2004) uses the term in-betweenness to mark the space between these dichotomies. He explains that, for some artists, it is this space that can both stimulate and encumber their creativity and that for some artists their creativity has come from exploring their mixed ethnicities. Mallon assesses that the art of inbetweenness often comes across in artwork, which talks about loss, homelessness, the uncertainty of identity and belonging. He identifies an interesting quote from Hastings-McFall and how she finds the space of inbetweenness as a place of opportunity, "It's a really free way to be, it's a really positive side of being in the liminal space, being in-between, where you're not one and not the other and you're never going to belong anywhere ever, fully, properly" (Hastings-McFall cit. Mallon 2004: 50).

In Hastings-McFall's interview with Robins, she explains how some of her work is not overtly Pacific but rather illustrates the situation where she was brought 
up with only one culture though her biological make-up is made up of two. As mentioned before, her Samoan culture was absent while growing up, however she cannot deny the impact that it has subsequently had on her life's work, "I go to Samoa and I don't belong there, there's no way in a million years that I'm Samoan but there's still that residue of it-that part of it is part of you, regardless" (Robins 2008: NP).

Hastings-McFall identifies that much of her work explores being in this liminal space, investigating the similarities and differences between the two cultures of her biological make-up. Kedgley (2013) briefly explores the different series of work by Hastings-McFall, particularly her Va-riant (2012) series commenting that this explored the space in-between, the interface between her two cultures.

While Hastings-McFall was growing up she would attend Sunday school, church and bible class whether she particularly liked it or not. She acknowledges that the knowledge she obtained from her Pākeha Presbyterian childhood subsequently provided a strong connection between her and her formerly unknown Samoan Catholic family. "It becomes a microcosm of the interaction and the Va (space between) that both unites and divides the different cultures" (Danse: Niki Hastings-McFall, 2011). Due to her Presbyterian-influenced upbringing she became especially interested by the colonial history of Polynesia and the influence that missionaries had on the Pacific as well as the heavy influence of the church and Christianity. Her piece Lei for George Westbrook (1997) created using the pages of hymnbooks crafted to represent flowers, strung together with seeds to form a lei (necklace). With this series, the artist wanted to question the role of the church in Samoa, critiquing the impact that Christianity has had on the Pacific.

Not all of Hastings-McFall's work displays overtly Polynesian iconography, however. Her Vanitas series, for example, draws inspiration from European art history to explore deeply personal themes. At the age of 47, Hastings-McFall was diagnosed with breast cancer. In a video clip filmed for an online series with the New Zealand Breast Cancer Foundation, Hastings-McFall talks a little bit of her 
experience of coping with breast cancer and she mentions how during that time a personal symbol of faith for her was a place in Samoa called Papase'ea (sliding rock) - a tourist attraction where, as Hastings-McFall states, it is common practice to slide down the face of the waterfall falling into the pool below. For Hastings-McFall, jumping from the top of the waterfall, despite having a fear of heights, brought a feeling of immense freedom; this experience stayed with her during her journey with cancer as if she had to keep jumping forward despite the fear she faced (Breast Cancer Foundation NZ, 2011).

After this period of her life she began her Vanitas series, which explored the transience of life. This series can potentially be read as Hastings-McFall exploring another aspect of vā, which is the vā between the human and spiritual realms referenced earlier in Chapter One. This series was inspired by the $17^{\text {th }}$ century Dutch still life paintings which contained a collection of objects that symbolised the inevitability of death and the fleeting of life - typically these paintings displayed art images of skulls, burning candles, clocks, hour-glasses, and flowers. Amongst these in the paintings would be other objects such as books, maps, musical instruments, jewellery, gold objects etc., to symbolise achievements and pleasures we have in life (Liedtke, 2003). Considering that Hastings-McFall doesn't paint she thought she would demonstrate a threedimensional version.

Hastings-McFall acknowledges and rather enjoys the irony of giving objects a second life, re-incarnating them into other forms - her Vanitas piece Swansong (appendix A: figure 5) which featured in her "Have a Little Faith" (2009) solo exhibition, demonstrates the transition from life to death. The little figurine in the centre of the piece has wings, symbolising metamorphosis, re-incarnation, and possibly an angel, as if the swan is transporting a soul across the mirrored water (Milford Galleries Dunedin, 2009).

The available literature on Hastings-McFall's artwork often highlights its best qualities. For example, in the exhibition booklet for her 2013 solo show In Flyte, Helen Kedgley, the Director of Pataka Art + Museum, describes Hastings-McFall's 
work as "meticulously crafted, visually stunning, innovative and conceptually intriguing" (2013:2). Hasting-McFall's personal values are clearly portrayed through her work. As Kedgley assesses, the recycling of objects and turning this into art has always been an important aspect to Hasting-McFall's artistic practice, as well as the reinterpretation of existing objects such as her Long White Cloud series (2012), which features an assemblage of 19 white lampshades that are covered in lei flowers. Her dual Samoan and Pakeha ethnic heritage, identity, and upbringing is a key aspect of her artwork. Hastings-McFall's work is creative, fun and witty but often has a serious undertone that is addressing themes such as colonisation in the Pacific, Pacific navigation, religion, references from Pacific and European art history, and themes of death, love and loss. 


\section{Chapter Three: Grace Taylor}

About the artist

Don't call me Samoan

Don't call me English

I am Afakasi

- Taylor, (2013:1)

Grace Teuila Evelyn Taylor is a mother, poet, performer and a teaching artist. Taylor is the co-director of Niu Navigations as well as a co-founder of the South Auckland Poets Collective (SAPC), the first spoken word poetry collective in NZ with poets of Māori and Pacific descent. Taylor is also co-founder, producer and creative director of the Rising Voices Youth Poetry Movement - the first and only youth poetry slam in New Zealand. In 2013 she published her first collection of poetry Afakasi Speaks and is working towards her second collection of poetry. She is also expanding her skills in the world of theatre, making her directorial debut in 2014 with Skins and then in 2015 she acted and wrote My Own Darling partnered with Auckland Theatre Company (Taylor, 2015).

Grace Taylor's mother is Samoan from the villages of Moata'a and Apolima and her English father is from Glastonbury, England (Taylor, 2013). Due to Taylor's dual heritage she strongly identifies as being 'afakasi, a term applied to those of mixed (usually Samoan-European) ancestries. 'Afakasi was used by both the German and New Zealand administrators in Samoa to assign status to those of mixed Samoan-European ethnic descent. Officials regarded 'afakasi as detrimental to both races as they threatened the purity of the Samoan race and weakened the European race (Salesa, 2000). However, those 'afakasi were also 
the bridge between the two races, having both cultural perspectives. ${ }^{3}$ This concept will be discussed further in this chapter.

Taylor initially wrote an extensive amount of poetry dedicated to her 'afakasi identity and published her first poetry book titled Afakasi Speaks (2013). In interview material Taylor expresses her initial experience of publicly sharing her poetry: she stood up, and spoke about what it was like to be of mixed heritage. The response she received was unanticipated as people in the audience also stood, showed immense emotion and applauded her. It was at this moment that she felt the power of poetry and how it could be used as an active tool to open up dialogue about issues that may often go unspoken (Taylor, 2013). This directly links back to what this thesis hopes to investigate: how the creative arts present accommodating spaces for articulating cultural mixedness amongst Pacific populations in New Zealand.

\section{Artistic Medium (Spoken word)}

Themes of mixedness have emerged as significant within a range of Pacific arts in New Zealand. The genre of poetry is an apt example of this. Selina Tusitala Marsh identifies as an afakasi, or half-caste, Samoan born in New Zealand. She states, "I often experienced a love hate relationship between the Samoan and European selves which simultaneously pulled and repelled me with rejection of who I was and expectations surrounding who I should be," (Macpherson et al, 2001:138). Tusitala Marsh often speaks about her identity and lived experiences through the use of poetry and in her academic work (Macpherson et al, 2001). Similar themes are expressed across a range of New Zealand Pacific scholarship and literature (Niu Voices, 2006; New Zealand Education and Training Support Agency, 1998; Mila, 2006; Taylor, 2011; 2013; Tusitala Marsh, 2009).

\footnotetext{
3 'Olaf Nelson and the place of afakasi in Samoa', URL: http://www.nzhistory.net.nz/media/photo/olaf-nelson-and-place-afakasisamoa, (Ministry for Culture and Heritage), updated 2-Sep-2014
} 
Within Pacific cultures, oral performance is not a newfound phenomenon: examples of oral tradition go back for many centuries, and include passing on cultural knowledge and practices through story-telling and recitation of genealogies (Wendt, 2000). In more recent decades, spoken word poetry has become an established phenomenon that is regularly performed through poetry events all over the world, including the many recent events here in New Zealand such as open mic nights, poetry slams and the establishment of poetry collectives. (Action Education, 2013). ${ }^{4}$

Spoken word poetry is written with the intention of being performed. According to Billy Collins, a U.S poet laureate, poetry reading offers a double connection: one with the poet who delivers his or her poem and another with the audience who have been united by a common interest. To better facilitate a sense of connection, the context of the spoken word poem often references current events as well as referencing issues and material relatable to a contemporary audience (Eleveld, 2005).

Spoken-word can also be performed in a competitive setting - typically referred to as a poetry slam. American poet Marc Smith is the creator and founder of the slam movement, which kicked off in Chicago in 1986 before gaining traction throughout America and abroad. Smith recalls observing boring poetry readings of the 1980s at open mic events and discovered a better way to attract people to poetry through slam. He comments,

Slam is not about making stars. It's about everybody all together in a room with their hair down and feet up. From its beginning, slam has been an art form and entertainment open to all people from all walks of life - young and old, rich and poor, blue collar and white collar, gays and straights, priests and prostitutes, biologists and belly dancers - a multi coloured, multi cultural gathering of people who love to hear and perform poetry

\footnotetext{
4 Spoken Word Guidelines: A best practice guide for educators. http://www.actioneducation.co.nz/uploads/2/9/8/1/29818351/spoken_word_ guideline_lo_res.pdf
} 
(Smith, cited in Action Education, 2013:2).

Slam was about injecting the art of performance into the art of poetry as well as about providing and enabling a space to build a community of poets joined with those who love the art (Eleveld, 2005).

Slam is a battle of words - where each competitor is able to recite an original poem where either guest judges or chosen members of the audience deliberate and provide critical feedback. Taylor and Jai MacDonald co-founded the Rising Voices Poetry Slam (in 2011) and in interview material Taylor compares slam to being the poetry version of American Idol in its design. Rising Voices is something much greater, though, as it is also a development program. The youth in this collective undertake a six-week poetry workshop developing their writing and performance skills prior to the grand slam where they then produce three original poems. Taylor is a key advocate for people, especially youth, to tell their own stories without others telling it for them. Youth have particularly connected with spoken word as it has acted as a platform for them to express their own voice, opinions and stories; as Action Education Manager Ramon Narayan states, when youth are inspired and have a platform to express themselves they are more prone to be actively engaged in their own personal development (Action Education, 2013: 2).

\section{Themes}

For audiences - both live and those listening or viewing via audio or video recordings-spoken word poetry can function on a powerful affective level. While we are aware that it is typical human behavior to experience emotions such as confusion, anger, loss, isolation, sadness and happiness and feel these emotions in varied intensities, much of the time it is just as human to believe we are feeling these emotions alone. Spoken word poetry has the power to build connections between the audience and the poet and for both parties to establish 
and discover similarities, reassurance, and awareness that we are not alone in the way we feel.

'Intertwined: Being 'Afakasi' (see Appendix B: Poem 3) was my introduction to Taylor's poetry - and listening to her words floating from the speakers back to me, despite not knowing Taylor personally, I was able to make a connection with her. Although her experiences were different to mine, they were still-relatable since a lot of her struggle was around her appearance. In this poem, in particular, you get a sense of imagery closely connected with the body; in emphasising contrasts between white and brown, Taylor explores a racial discourse and different symbols of representation that express her experiences and particularly her journey and the struggles she has faced, both external as well as internal.

Bouncing from one skin to the next

Putting my culture on to fit in with the rest

Fighting to not be the minority

In a vain attempt to have them accept me (14-17)

A term that comes to mind when reading this passage is polycultural capital. This is a term coined by Karlo Mila-Schaaf, building on Bourdieu's concept of cultural capital (Mila-Schaa,f 2010; Mila-Schaaf and Robinson, 2011). Polycultural capital implies being rich in culture. The prefix 'poly' can refer to both 'many,' as in abundant, as well as suggesting a play on the word 'Polynesian'. As already mentioned in Chapter One, Polynesia is one of the three regions in the Pacific, and a large portion of the Pacific population in New Zealand associate and identify with the islands in this region. Karlo Mila-Schaaf uses this term to best describe the opportunities present in having a foot in more than one cultural world: "the term 'polycultural capital' also encompasses agency and the ability to negotiate multidimensional resolutions to intercultural situations" (Mila-Schaaf, 2010: 168). 
I think many people of mixed ethnic background utilise their polycultural capital. In Taylor's passage above, the tone is not positive, however the verse makes the reader aware that there have been contextually responsive choices made. In this passage the terms she uses-'bouncing', 'to fit in', 'fighting', and 'vain attempt'symbolise exertion of energy trying to continuously move between cultural identities in order to feel accepted by others. The passage also illustrates conflict within oneself in trying to justify cultural components, based on feelings of judgment experienced either from within or from others. This passage is one that many people who are still in the process of self-acceptance might relate to. Somewhere within this conflict is a demand for legitimacy; this is seen throughout the poem and particularly in the verse,

\author{
I'm half Samoan \\ say it loud \\ say it proud \\ feeling I gotta be a little louder \\ speak a little browner (38-42).
}

As already mentioned in a previous chapter, research has shown that there is a demand for legitimacy placed on people claiming to be part of a minority group, particularly for those that are of mixed ethnicity, and this demand comes from both the minority group as well as the majority (Keddell, 2006). This passage above delineates what this legitimacy can be like for people (particularly of mixed ethnicity) who are under this form of scrutiny; this passage is a direct declaration of her Samoan heritage despite the fairness of her complexion. This legitimacy claim is further underscored with the lines, 'What I gotta do to prove / I'm just as Samoan as you' (47-48).

Academic work on diasporic Pacific identity identifies constant negotiations and debates over cultural authenticity. For example, Marianne I. Franklin's 2003 essay “I define my own identity: Pacific articulations of 'race' and 'culture' on the Internet" discusses two online public discussion forums, the 'Kava Bowl' and 'Kamehameha Roundtable'. These forums became a network for Pacific people 
around the world to come together in cyberspace and meet other Pacific people and have conversations about their experiences and the effects of Pacific Island diaspora. The essay explored discussion threads that sparked intense debates because of the essentialist views that were shared. These include comments from a thread that started with an initial post entitled "Fake Polynesians $(100 \%$, 2 February 2001, KR)",

I wonder why people who do NOT look Polynesian go around telling people they are? A white woman came up to me today and asked if I was Samoan. She than tells me she is $1 / 4$ Samoan. Big deal. She looked white to me. I can tell she was bragging as to suggest that she is one of us but thankfully did not look like one of us. I guess my point is, if you don't look Polynesian than it doesn't matter. The truth is when you go out in the real world. I'm sure you will not bring that up with your white peers. (100\%, 2 February 2001, KR, cited in Franklin, 2003:472)

This argument implied that people are treated in accordance to their appearance and how those who look 'white' or not overtly Polynesian are at more of an advantage in a racist society (Franklin, 2003). Many others in the online thread countered with a lot of fiery disagreements to discredit 100\%'s purist claims:"I can understand your bitterness because there is still racism in our society. But don't you see? You are perpetrating the ignorance..." (Meilakepa, 3 February 2001, KR, cited in Franklin, 2003:473). Other comments disapproved of some aspects of 100\%'s post but agreed with other aspects: “... I understand what you mean when people like that lady just say that when it's convenient like when it comes to scholarships, college admissions, Polynesian club memberships etc. but still its not hurting you or me, so don't sweat the hype" (tOnGanInMaIdEn, 2 February 2001, KR, cited in Franklin, 2003:473). These arguments from the online forums studied by Franklin are the same type that are explored in Taylor's poetry: Taylor particularly engages many of the different views that people have taken on mixed ethnicity, specifically 'afakasi in her "What is Afakasi" poem which will be addressed later in this chapter. 
Aimie Cronin, a former journalist and current freelance writer, wrote an article on Grace Taylor for Auckland's Metro magazine days before her "My Own Darling" (2015) theatre show debuted. Cronin depicts some insights into Taylor's life from an interview that she incorporates into the article. Taylor speaks about her younger years and how she really struggled with identity, and particularly made reference to her light complexion.

It wasn't cool to be white. If you were white the assumption was that you were rich, you were brainy, that you would have a nice lunch, that you were a bit of a nerd, and I hated all of that. I went through a phase where I hated being fair-skinned, absolutely hated it. I never felt like I had anything to give that would show I was part-Samoan. I used to feel that my Mum was the only proof (Taylor, cited in Cronin, 2015).

This quote from Taylor strongly relates back to 100\%'s comment suggesting that those who look white had "skin privilege," or access to benefits in a racist society that privileges whiteness, and the comment directs a lot of resentment towards this assumption.

Taylor's comment that, in her younger years, she felt she needed to have her mother close by in order to show her she was indeed Samoan is echoed in the poem 'intertwined: Being Afakasi'.

Then again,

I remember wanting my mum around me

as if she were a ticket

to prove I'm from the Polynesian family

now who's whispering racism? (52-56)

Halfway through the poem Taylor slowly starts to come to the conclusion that her inner battle with her appearance and identity is more about her own self- 
acceptance. We are brought back to the image of body in the verse 'my blessed island curves / in this white skin / my English words / wrapped in humour that is undeniably Polynesian' (83-86); this verse carries a positive tone and we see how both white and brown have been intertwined as the title suggests, this time without struggle or conflict. This poem explores the journey encompassing struggle and self-acceptance of identity.

You can feel the power behind the words created by Taylor when her poetry is spoken aloud, as if the words on the page have been given a life of their own. Through her expressions, her movements and tones of her voice, it becomes almost hypnotic - completely captivating. Taylor's poetry has become influential, across New Zealand, having her own TED Talk and performed pieces on COCONUT.TV. This is aided by the easier accessibility to spoken word through media platforms such as YouTube and Facebook, particularly for our young generation who more frequently use these platforms of social media. Poetry in the spoken word form, as I have experienced, can be a powerful tool, as it has the ability to make an audience feel what the poet is feeling, regardless of whether they have gone through the experience the poet is sharing. This is why it is so valuable when Taylor explores the taboo subjects in her poetry because the power that spoken word has can create feelings of empathy and understanding.

\section{'Afakasi}

Historian Damon Salesa discusses some of the history of the Samoan half-caste. The term 'half-caste' is an imperial term, and in Samoa before the nineteethcentury there was no word or even an equivalent concept, thus it became the one transliterated from English, 'afakasi, that was adopted to describe someone who has one Samoan parent and one Palagi (white) parent. Prior to this, the Samoan system of understanding descent and belonging was based on genealogy:

In one sense "half-castes" who lived in Samoan villages were as

"whole" as their neighbors. In another sense every child was a kind of half-caste, even if both halves were Samoan. Individuals 
would trace their genealogy back to different villages and would often feel those ties in very different, practical, ordinary ways. One's identities were plural, and this was expected. This was the nature of Samoan genealogy: it was multiple, historical, and responsive to context. (Salesa, 2006: 83)

As Salesa emphasises, even if an individual was of full Samoan descent they still had two different genealogies, one tracing their father's bloodline and another their mother's bloodline. The important factor was being able to trace their ancestry. Imperial intervention affected and thus changed Samoan life with the introduction of many new concepts including 'afakasi (Salesa, 2006) and since then the term has continued to evolve and take on multiple interpretations.

In the poem, 'What is Afakasi?' Taylor explores what others (community members, scholars, western philosophers) have contributed to the discussion and debate of the term 'afakasi. Taylor's previous poem 'Intertwined: Being 'Afakasi' (Appendix A: poem 3) was about her personal journey on the road to self-discovery. This poem, 'What is Afakasi?', examines the politics of the term itself, by exploring the negative and positive connotations.

As mentioned briefly in Chapter One, the products of miscegenation were seen as a representation of impure blood; this was also believed to be the adulterate of 'pure' blooded cultures. In 'What is Afakasi?', the line 'Afakasi is part / dying and living' (27-28), offers a contradiction. On the one hand, 'afakasi is part 'dying', refers to ethnic dilution over generations thus lending to the implication of a dying race. On the other hand, in contrast to this idea, creating new life means the continuation of a race and potentially its culture.

Afakasi is running a race

you once said

races against races

where are we placed?

First, second or third? 
But I see race beside a race

To a finish line

That will challenge minds (36-43)

When this poem is performed, Taylor recites this passage with her elbows bent, hands shaped into fists and arms moving against her body, as if to action her running. Taylor's analogy in this passage illustrates a picture of a competitive sprint, or running race. Normally in a race people will have a numeric placing, to show who was faster than the others. The message presented in the passage above is that ethnic races shouldn't be compared or ranked as better or higher in social stature against one another. Taylor draws us back to a 'finish line', symbolising an end and a beginning: a beginning to see races as equal and an end to the idea that a race or cultural identity such as 'afakasi can be more or less prestigious than another. 'Afakasi is running a race' ties into the next verse, possibly referring to the idea of superiority, 'overprivileged... excused from fa'a Samoa / yet granted scholarships / as if blood and skin is currency / for opportunity' (44-50). Historically, Samoan half-castes recognised by their European fathers were often more likely to be part of a more privileged social environment, being offered opportunities that other Samoans were not granted, such as education and access to social clubs (Salesa, 2006). 'White' is often expressed in Taylor's poems, due to her fair skin complexion inherited from her English ancestry. 'White' can often be a symbol of imperialism, power and superiority - and thus is associated with greater prestige and opportunity. As Taylor expresses, it is often presumed that 'afakasi are more inclined to have better chances and greater leverage in society due to their accessibility to the assumed privileges of the white community.

In post-colonial discourse there has been extensive analysis and theorising around the mixture of races. As mentioned earlier in this thesis, the term hybrid has been used as well as critiqued for its negative connotations. Such critiques are noticeable in the tone of this next verse,

Afakasi is hybrid 
they said

as if we are scientifically designed

injected

synthetic

realigned

into an unnatural state of being

I'm Alive!

I'm Afakasi-stein (51-59)

'Hybrid' has also been associated with fictional characters in books and films, typically referring to crossbreeding that has created monsters, creatures or people with special abilities. During her performance of "Afakasi is dead", as per the video footage uploaded to Taylor's YouTube channel on April 29 2013, she places emphasis on the words "Afakasi-stein", with a smile on her face and her arms stretched out wide, with both the term and actions playing on the Mary Shelley (1818) monster created scientifically by the character Victor Frankenstein. Her audience share a laugh after she actions this and I appreciated the humourous tone she uses at the end of this verse by including 'Afakasi-stein'. As part of Shelly's story, the 'monster' was feared and loathed by both creator and society because of his gruesome appearance, however there are moments captured in the book that reveal the monster's vulnerability and feelings of complete loneliness. He may not have been such a monster if people did not treat him as such. This is akin to the idea of looking beyond the colour of one's skin that Taylor expresses earlier in this poem as well as in her poem 'Intertwined: Being 'Afakasi'.

Often as a result of lacking certain Pacific phenotypic characteristics, mixedancestried individuals have tried to showcase their ancestral ties through other means. For Taylor in particular, she has a tattoo on the back of her neck inspired by customary Pacific Island cultural designs and motifs. Sean Mallon has contributed a lot of research to the literature on the art of tatau. In the 2002 publication Pacific Art Niu Sila: The Pacific Dimension of Contemporary New Zealand Arts, Mallon discusses how often Pacific individuals, especially in New 
Zealand, have chosen to receive tattoos/tatau as an affirmation of their ancestry: tattoos can represent blood ties to a nation or culture and therefore becomes a symbol of the wearer's identity. Taylor both embodies this phenomenon and also explores it in her poetry.
Afakasi is inked up
The tap-tap tap-tap
Bleeding the brown
to the surface
Creating maps of heritage
A badge of ancestry (93-98)

The term 'bleeding' as part of this verse can refer to tattooing and the piercing of the skin. It can be read as feeling 'brown' but lacking the right amount of melanin in the pigmentation, so turning effort towards drawing out the 'brown' from a bloodline not visible on the surface, and as said displaying this as a 'badge of ancestry' onto the skin.

Sean Mallon (2010) has described this need of tattooing as a way to demonstrate one's cultural roots, very much like the expression that Taylor uses, "a badge of ancestry". This can particularly be the case for individuals who cannot be immediately identified by others as being Samoan or of Pacific descent, but certainly hasn't been limited to just them. As part of traditional rites of passage, men and woman have received tatau such as the pe'a and malu that may have incorporated similar tatau designs given to their ancestors, so thus presenting a symbol of continuity from generation to generation (Mallon et al, 2010).

The repetition of 'Afakasi is...' used throughout, can almost be read as a poem within the poem, and it highlights the journey of this term, how others have interpreted its meaning, and the stereotypes associated with it that Taylor explores in this poem,

Afakasi is dead (3) 
Afakasi is part (27)

Afakasi is running a race (36)

Afakasi is overprivileged (44)

Afakasi is hybrid (51)

Afakasi is cut up (64)

Afakasi has no right (73)

Afakasi is prized (80)

Afakasi is inked up (93)

Afakasi is redundant (99)

Afakasi is my generation (110)

Afakasi is all encompassing (144)

Afakasi is not dead (150-151)

Nearing the end of the poem Taylor offers her own answer in response to the title, "What is Afakasi?" 'Holding on to this term / with a tight fist / no more Afakasi / must mean / I don't exist' (104-107). This line can be set against societal debates arguing to eradicate the term 'afakasi because of its association with British imperial notions of race and hierarchy and the the historical political tension and the offence it's created. Some critics believe the term is 'redundant' and not as suitable as new, more politically correct terms, such as multi-ethnic or mixed (Salesa, 2000). Online there is an informal discussion forum called "Talofa Lava," a place with 2,283 registered members, where topics are posted and anyone that is a member can comment with their opinions. 'Afakasi people' became a topic of discussion where various opinions were expressed by a number of people. Many of the comments voiced mixed views on the term: some members on the discussion did not find anything wrong with the use of the term, others believed it to be a racist term and thought it shouldn't be used, and others found it offensive. In contrast, Taylor defends the term 'afakasi, because this is what she identifies with. By doing so she is also defending herself: 'half caste / smashing cast / moulds constructed by others / casting shadows / on taboo territories' (128-129). This verse illustrates a desire to break free of certain

5 The Talofa Lava forum: http://42976.activeboard.com/ 
social customs by opening up and bestowing attention on 'taboo' or prohibited topics. Also in the last few stanzas of the poem, Taylor speaks in third person, 'Shes not dead / she evolves' (122-122), 'she is / breathing / changing' (159161), 'Afakasi speaks/ and She is heard' (166-167). Referring to Afakasi being a 'she,' Taylor takes the term on as a personal affirmation and holistically embraces this label, instead of belittling it. Just as the term has evolved and changed in meaning over its journey from when it was first used, so has Taylor herself.

Vā

I am the va

So cut me up

Scatter me among yourselves

And taste the bitter sweetness

Of the space between

Brown

And

White

Mud. (2-10)

Taylor wrote this poem, titled 'I am the Va,' in dedication to Albert Wendt's contribution to the vā discussion. The vā reflects the liminal space and thus Taylor relates it back to her identity and purpose as an artist. The poem is physically cut up on the page as if the vā-a concept that describes interrelational space and the space that connects, can be visibly seen through this poem, each line, though dispersed, are still part of the whole, still interconnected. The vā incorporates an idea of relationships and connections we have with people, the environment and the cosmos. This certainly does not exclude the relationships within oneself: self-acceptance should be an important aspect of the vā - nurturing the relationship with yourself, enabling you to nurture proper relationships fully with others. 
Taylor acknowledges both her genealogies, that belonging to her father and the other to her mother, as both need to be nurtured and respected within the vā: 'you want me to choose / to condemn and stone one side of me / making me believe / one half is a victim'. Cronin (2015) also captures this in her article on Taylor,

She got frustrated with her mum-“why didn't you teach me Samoan?" She caught herself one day, wishing to be browner, and she thought about the father she loved and saw that her longing discredited him. More and more it became important that both parents be acknowledged, and in a way she reclaimed the word "afakasi" to mean something resembling the power that she is.

Taylor explores the need to nurture the connections within herself in order to not discredit the relationship she has with her parents; she cannot choose to be Samoan or English because she is not fully any of them, and this tug-of-war can disrupt the vā between cultures, families, and between one's own self. Instead she can embrace the power of having polycultural capital.

my Va

is neither here

nor there

not brown

nor white it belongs in nothing and exists in everything (46-52)

Many people in Aotearoa face issues related to culture and identity, Taylor has taken ownership of this complex space of identity and told her story. Using her artistic platform, Taylor has thus created a space to inspire and help others tell 
their own stories. 'Scatter me among yourselves /And use me / To fill the gaps.' (53-58). Taylor, who seems grounded in her identity, uses the experience of her journey to assist others, particularly youth, on their own journey whatever that may be.

As mentioned, Taylor's predominant theme for the poetry she's released thus far is 'afakasi, where she explores in depth different scenarios, feelings and experiences that comes with being of multiple ethnicities. However, no-one ever possesses simply one identity; from Taylor's collection of poetry you also see other roles and identities that she possesses, like being a strong independent woman, a mother, her identity as a daughter, and the love she has for her parents which she has captured in poems such as 'Tinā 1', 'Tinā 2', Tinā 3', and 'Dad'.

More recently Taylor has also been involved in theatre work. In 2014 Taylor spent her Creative New Zealand Arts internship with the Auckland Theatre Company. This is where she directed Skin, a spoken word poetry theatre piece as part of the Next Big Thing - a festival of work presented by and celebrating Auckland youth. Auckland Theatre Company subsequently commissioned Taylor to create a new piece, My Own Darling. The concept of this poem was inspired by the poem "Be Nobody's Darling” by Alice Walker.

My Own Darling explores Auckland's urban life. Taylor created five characters in the play. One of the characters, Gritgirl, played by Gaby Solomona in the production I watched, is a girl with a tough exterior, her attitude carried with a sliver of malevolence. As the show continues, we get to understand Gritgirl the more we see her, and she starts to express some of her vulnerability and the struggle she's gone through that her anger and attitude cover up. The audience learn that the "tough exterior" is a façade she wears to get her through her daily life.

The next character was the Man from the Maunga, played by Fasitua Amosa. This character was inspired by a man that Taylor observed last year while up on Mt Eden. Taylor recalls seeing that the man had a loud speaker fastened to his 
motorbike, blasting music, confidence exuding from him as if he didn't have a care at all of what people thought of him. In the 2015 production, Maunga's "motorbike" was represented by a long oblong box that Fasitua sat on, horseback style. He had his arms in front of him as if holding bike handles and he wore a bike helmet. Maunga was the character with the abundant supply of knowledge; whenever he was on stage he would often share historical facts and other pieces of knowledge about the city. My impression is that his character represents freedom in the show. (Taylor, Radio New Zealand, 2015).

Then there's the aunty - another character played by the male actor Fasitua Amosa. She is the tough love Samoan aunty that is very straightforward in her opinions. Though this character could be rather callous, particularly towards a fourth character, Teuila, she was also the most humorous in the play. She's reminiscent of the typical Samoan lady next door. As the play continues the audience start to discover that this woman has her own reasons to laugh at pain - which you'll find with many Samoan women (Taylor, Radio New Zealand, 2015).

The character Teuila, played by Grace Taylor, incorporates a lot of Taylor herself. Teuila, is the poet who observes her surroundings, the people around her and takes notice of her changing environment. She is also adapting to a new life, becoming a single mother. The final character in the play was the Patron, another character played by Gaby Solomona-a well-meaning Pakeha arts patron who expresses her passion for Pacific arts. Though she has an unintended patronizing demeanor, she means well and was a playful and fun character for Taylor to create.

This play demonstrates different characters within Auckland that Taylor has come across over the past couple years; even if their encounter was brief, they stuck with her. Taylor is notorious for talking about taboo subjects, and there are stories presented in this play that members of the audience may not be familiar with. Taylor once thought that theatre would be restrictive to her art, but instead it really stretched her poetry, pushed boundaries and being in character gave her 
the courage to say even more than perhaps Taylor would have expressed otherwise.

Grace Taylor places mixedness at the forefront of her art. She uses poetry, and more recently theatre, to highlight her experiences of Pacific mixed identity and other personal aspects of her life, like being a single mother. The loaded term 'afakasi, which shares similarities with the term hybridity in terms of its colonial meaning and contested politics, has been a defining tool in Taylor's spoken word poetry to create dialogue about unspoken topics and experiences that many people can relate to. 'Afakasi was the official term used in Samoa to describe people of Samoan - European heritage and was largely used in the derogatory sense (Salesa, 2000). Taylor explores the debate around the term 'afakasi, through the expression of her story and through spoken word poetry. Taylor uses the line 'Afakasi-stein' in her "Afakasi is not dead" poem to show that the mixing of races has been viewed horrifically in the past. She explores how there is vulnerability about being in this position and she demonstrates her selfconciousness about how people think and act towards this topic. Despite its dubious history, Taylor uses 'afakasi as a phrase for self-empowerment and claims ownership over the word to give it new life and meaning -encapsulating the word for all that it is and deciding how it will be thought of - through her art.

The vā becomes a large underlying concept in Taylor's work, especially in 'I am the Va', used to refer to the inter-relational space between people. Throughout Taylor's journey she has realised the importance of respecting the meeting of both cultures and recognising both family lineages, so as to not disrupt the vā between her, her parents and the families from both lines. Taylor claims this space for herself as an 'afakasi as the place in-between two cultures, as neither here nor there, belonging in nothing and existing in everything. 


\section{Chapter Four: Aaradhna}

About the artist

Aaradhna Patel-hereafter referred to by her stage name, Aaradhna-was born in 1983 in Wellington, New Zealand and comes from a large musical family. She is of Indian and Samoan descent and the eldest of five. She states that in her household, "dad will be speaking Indian [sic] sometimes, mainly in swear words, my mum she speaks Samoan as well, it's not just Indian and Samoan, it's like mixed" (Aaradhna, 2011: 9:19-9:30). Aaradhna initially gained fame for her contributions to the Adeaze hit single, "Getting Stronger." Aaradhna's father has roots in Navasari, a Southern Gujarat village. Her Samoan mother has links to the villages of Papa Uta, Auala and Falealupo. As a child, Aaradhna began by singing traditional Samoan songs and trying to imitate the intricate musicals she saw in Bollywood movies (Aaradhna, 2009).

Aaradhna's parents are both very vocal around the house in their native languages and are also both singers. Sia'a Patel, her mother, was never without her guitar, as Aaradhna recalls in interview material (Oliver, 2015). Sia'a writes and sings music as part of the choir at church. Jawanti Patel, her father, also sings Indian songs, performing at birthdays, weddings and Diwali festivals. In a 2011 episode of the television programme 'Fresh' that Aaradhna hosts', her parents are briefly featured and her father expresses his influences on Aaradhna, offering the example of when she would accompany him on his paper runs listening to loud Indian music in the van. She also admits that her and her siblings would often watch Bollywood movies with him and sing along to the songs (Grindin, 2013). Her mother was never shy with her voice, and she would often belt out songs around the house. Evidently both her parents were very influential on her music career, and at the very young age of 10 or 11 Aaradhna wrote her first

\footnotetext{
${ }^{6}$ Aaradhna on Fresh TV: https://www.youtube.com/watch?v=_ZupA5tYQvk
} 
R\&B ballad, titled 'Do you love me or do you love her,' a song that was inspired by the music she was listening to at the time (Oliver, 2015).

However, it wasn't until she entered her first talent show at the age of 13 that Aaradhna knew she wanted to be a professional singer. Unable to play an instrument, she used her own voice to write and construct music. By intermediate school, she was beatboxing and layering vocals, utilising any recording device that she had at the time, including an answering machine and three-way calling that her family had installed on their phone line. Henry Oliver takes note of these earlier days in a recent interview with Aaradhna featured in the Sunday Star Times (2015),

She would record her beatboxing as a message on the answering machine and then call herself, play the beatbox message on one line, sing over it on the second line, and record the two tracks on the third. She would repeat the process multiple times, adding multi-part vocal harmonies (Oliver, 2015).

Interestingly, Aaradhna also went on to form a five-piece girl group called Lovera in high school. By this stage she obtained access to a tape recorder and, using the family stereo as a "makeshift multi-track studio," (Oliver, 2015) she was able to record her demos, sending them out to all the music record companies she could find in New Zealand. Although she demonstrated great initiative, this wasn't how she received her first break. That came the day she received an unexpected phone call from her aunty telling her that the co-founder of South Auckland record label Dawn Raid Entertainment, Danny ‘Brotha D’ Leaosavai'i, was over at her grandmother's house getting his hair braided. She went over to her grandmother's and sang to Brotha D. Though usually very shy when asked to sing in front of someone, she saw this as the opportunity she was waiting for; this fortunate encounter was how her music career commenced.

Aaradhna relocated to Auckland where Dawn Raid was located and featured in collaborations with other Dawn Raid artists, including vocal duo Adeaze and hip 
hop emcee Savage, which provided an entré into the music scene. She subsequently had solo chart success, achieving a top five single in New Zealand with 'They Don't Know' in 2005, followed with 'Shake' in 2006, and since then has released three albums: I Love You (2006), Sweet Soul Music (2008) and Treble \& Reverb (2012). She has also collaborated with other New Zealand artists, including P Money, David Dallas, and Che Fu; with Australian artists Sammy J and Paul Mac; and with Hawai'i-based artist Fiji.

At the 2013 Vodafone New Zealand Music Awards, Aaradhna won three awards, including the award for Best Album for Treble \& Reverb. She won a further six awards at the 2013 Pacific Music Awards, winning every award that she was nominated for. She was the first artist to receive that many awards in a single night in the 9-year history of the event. This included Best Urban Artist and Best Female Artist, which seemed rather fitting as the theme for that year's Pacific Music Awards was acknowledging female Pacific music artists, past and present.

Aaradhna signed a record deal with US-based label Republic (Radio New Zealand, 2013) and released another album, Brown Girl, in 2016. Aaradhna expressed through her Instagram account that this would be her last album (2015). In consideration of her fans, she then posted another photo and comment on her Instagram to add some clarification: "It doesn't mean it's my last piece of music to offer, I meant last album... I want to concentrate on settling down starting a family and all that good stuff' (Aaradhna, 2015). Many of Aaradhna's supporters were disheartened to hear that Brown Girl may be her last album; however, she has now removed the post so, as she alluded, perhaps there is the possibility of more music/albums to come after Brown Girl.

\section{Music Background}

New Zealand's Māori and Pacific communities have been major pop music enthusiasts. Their love of dance has been a contributing factor in their choice of music, which they've then utilized and adapted over the years. "While New Zealand's record charts and sales mirror global trends, Pacific Islanders show a 
preference for country-style ballads and love songs, African-American music, and the performance and dance aspect of pop" (Zemke-White cited in Mallon \& Pereira, 2002: 117). Research indicates the preference of NZ Pacific people for American pop genres and particularly African-American pop music styles such as doo-wop, soul, funk, hip hop and contemporary R\&B. (Henderson, 2006; Gibson, 2003; Mallon \& Pereira, 2002; Pearson, 2004; Verán, 2006; Zemke-White, 2005). This is evident today: for example, radio stations with bigger Pacific audiences play music that is centered around American pop, hip hop and R\&B/soul. For example, the majority of music that government-funded, Pacific-targeted station Niu FM plays is from these genres. Niu FM's format was discussed as a case study in the report "Broadcast Programming for Pacific Audiences for NZ on Air" by Tim Thorpe Consulting Ltd, Catalyst Pacific Ltd, and SDL Consultancy Ltd, in association with Emma Powell and April Henderson. The report discussed the findings from a survey taken by a selection of Niu FM's audience:

Niu FM had strong listenership and awareness amongst Pacific peoples, in particular the Samoan cohort and young people generally. This was in most part due to the range of music that was played by the station and the connection that it fostered amongst Pacific communities with the dissemination of information pertaining to local and community events and its provision of Pacific news. (14)

Similar characteristics make Flava FM another popular radio station amongst Pacific communities. At the Pacific Music Awards, most of the musicians that are nominated fit within the hip hop, R\&B/soul and reggae genres. Additionally, surveying the three New Zealand Idol programmes won by people of Pacific descent (Ben Lummus in 2004, Rosita Vai in 2005 and Matthew Saunoa in 2006), the eventual winners would often sing songs from these genres. As part of the 2015 New Zealand X-Factor grand finale, the two finalists, Beau Monga and Nyssa Collins, performed a Pacific-inspired combination of cultural and modern song and dance. Collins, an R\&B artist, took the popular song "Don't dream its over" by New Zealand pop/rock band Crowded House (1986) and offered a 
soulful Samoan and English rendition of the popular song. choreographed with Samoan cultural dance (Scherer, 2015). There is also a significant presence of hip hop and R\&B at the annual Pasifika Festival in Auckland, and artists working in these African American-influenced genres are also making regular features on the weekly television shows Tagata Pasifika and Fresh.

Despite the multiplicity of globalised pop styles accessible in New Zealand, Pacific young people have gravitated towards these styles of soul, $R \& B$, and hip hop and have used this music to tackle complex issues such as oppression, colonial histories and other political matters, (Zemke \& Televave, 2011). The attraction to this form of music is thought to come from the stories and sounds of African American history, religion and the strong connections to gospel music that Pacific people can relate to due to their own religious practices. Mass media carried these African American styles to New Zealand and in conjunction with Pacific people's own cultural music, ideologies and languages, they were able to integrate these Pacific cultural elements with American-based pop styles and create a unique version they could call their own (Zemke-White, 2005). This led to 'Pacific hip hop', 'Pacific soul' and 'Pacific pop'.

Since the 1960s and 1970s, many Pacific soul, R\&B, funk, hip hop and pop artists from both New Zealand and overseas have served as inspiration and musical icons for Pacific people. In the 1970s, The Yandall Sisters made Pacific pop history with their hit song 'Sweet Inspiration.' They also hosted their own television show in 1974. The Samoan sisters resembled prominent US groups such as The Supremes, but with a Pacific sound which became commercially accepted in the New Zealand music scene. Many believed that The Yandall Sisters were pioneers for Pacific female entertainers; they became inspiration for upcoming female artists (Zemke \& Televave, 2011; Zemke-White, 2002).

By the 1980s and '90s, pop and R\&B were embraced by performers such as Annie Crummer, Ardijah, Lole, and Ma-V-Elle. These styles continue to be popular through to the $21^{\text {st }}$ century. Some popular artists sing music in their own indigenous languages but still within the pop/R\&B genre. For example, 
Hawai'i-based artist Fiji, who has a large local following amongst NZ Pacific people and frequently tours to New Zealand, has created a striking fusion of Pacific R\&B with songs in multiple Pacific languages, as well as those in English (see, for example, Fiji's Indigenous Life 2008). Fiji, and his Samoan American protégé J Boog, have served as inspiration for a range of NZ-based artists. Reggae and hip hop music have been especially popular amongst Pacific populations. Artists such as Che-Fu fused rap and reggae in his album $2 b$ S.Pacific (1998). In addition to its musical components, DJing and MCing, hip hop culture includes breakdancing and graffiti and is particularly popular amongst Māori and Pacific youth; scholarly commentators argue that it enables empowerment and creates a space for expression. (Gibson, 2003; Henderson, 2006, 2012; Zemke-White, 2005).

It is evident that Pacific musical artists have embraced and adapted African American popular music forms while also celebrating Pacific cultures, whether overtly through lyrics or merely by personae and images (Zemke-White, 2002). This could be due to the overwhelming influence of African American popular culture and the mediated examples of African American struggles for equality that resonate with Pacific artists.

\section{Artistic Medium (R\&B/Soul)}

It was in the 1950s that rhythm and blues first became well established as a genre in the US.

The term rhythm and blues was first used as a marketing label to identify all types of music recorded by African American artists. Introduced in 1949 to replace the race music label (a term in use since 1920), rhythm and blues encompassed all black musical traditions, including rural and urban blues, boogie-woogie, black swing, jazz combos, vocal harmony groups, and club lounge trios. It also identified a musical genre that began evolving in the mid-1940's as reinterpretations and 
hybridizations of vernacular traditions. Although the blues provided the foundations for rhythm and blues, other elements came from jazz, spirituals, gospel, and mainstream popular music. By the 1960s, gospel elements began to dominate and transform rhythm and blues into a distinctive genre labeled soul. (Garland Encyclopedia, accessed 2016) ${ }^{7}$

Maintaining itself as a 'black' popular style, rhythm and blues then infused different genres such as pop, doo wop, soul, funk and disco by the 1970s, showing the fluidity of these music genres. Rhythm and blues, more frequently known now by the abbreviation R\&B, has become the pop music for broader America-not just African Americans. Many singers will collaborate with rappers, joining hip hop and R\&B together. For example Beyoncè may sing a song and hip hop artist Jay Z will rap in a bridge, or vice versa, Jay Z will rap a song and Beyoncè may sing in the chorus. "Interacting but independent, these two African American pop music genres, exemplify two aspects of contemporary masculinity: the style, sophistication and romance of the r' $n^{\prime} b$ singer, as foil to the danger, brutality and rebellion of the rapper" (Zemke-White, 2005:97).

This is echoed in New Zealand where many R\&B groups/artists are linked with hip hop and rap groups/artists, for example the group Nesian Mystic featured both rappers as well as singers, and they could then combine both elements in their songs. Kirsten Zemke-White argues that R\&B normally gets overlooked in academic writing while hip hop takes center stage. She believes this is because of R\&B's "mainstream and commercial character as well as its textual and thematic light-heartedness" (Zemke-White, 2005: 95). As mentioned previously, Pacific hip hop and R\&B show similarities with their American counter parts, however, Pacific R\&B and hip hop artists offer a unique localised cultural product by combining these American inspired forms with Pacific flair, utilising their

\footnotetext{
${ }^{7}$ Garland Encyclopedia, R\&B definition. http://search.alexanderstreet.com/glnd/view/work/bibliographic_entity\%7Cbi bliographic_details\%7C326923\#page/697/mode/1/chapter/bibliographic_entit y\%7Creference_article\%7C1000226116
} 
instruments and languages and thus creating a new genre and sub-culture that reflects their own identities, in a contemporary way. The tools that they have borrowed from African American styles have given them a platform to express their own unique styles representing their people, where they come from and how they live.

\section{Themes}

Aaradhna's music demonstrates the close links between R\&B and hip hop here in New Zealand, just as the two genre are closely linked overseas in the USA. Kirsten Zemke and Su'eina Sharon Televave (2011) argue that Aaradhna can sing to the standard of an American R\&B artist and liken her to the hip hop divas Mary J. Blige and Erykah Badu. As already mentioned, Aaradhna has also worked alongside many other Pacific artists, including her music tours and gigs with Fiji and Sammy J on separate occasions. She's even collaborated with artists from different mediums: her music clip for the song 'Great Man' (2013) was dedicated to her long-term romantic partner, and featured Auckland-raised international award-winning urban dance choreographer Parris Goebel (herself of mixed Samoan descent) and members of her Palace Dance Company dancing in the music video. This is another example of Aaradhna's efforts to collaborate with other New Zealand artists.

Aaradhna's music collaboration with Mareko \& Baby Downn (the latter of the group Brownzville) for the song 'Soul Food' (2007) is particularly noteworthy. In this union Mareko raps lyrics expressing that 'island food' is the real 'soul food', and the lyrics also include appreciative mentions of a variety of Pacific Island foods. These include taro and turkey tails. Turkey tails are offcuts of the US poultry industry exported from the US to Pacific islands. Laden with fat, they provide a cost-efficient and satiating food, which warrants their appeal to Pacific people. Samoans also love the taste. However, their high fat content got them banned in Samoa for a period of time. 
Nancy Pollock has written extensively about particular staple foods in the Pacific Islands. The evidence she provides shows that taro is a staple root vegetable in Samoan (and other Pacific) communities, along with breadfruit, yams, and green bananas. For the Samoan communities both in Samoa and overseas, taro is the preferred starchy vegetable, (Pollock, 1992: 48); if available, it normally accompanies most dishes of food.

No feast in New Zealand is complete without some taro, a whole fish, some chicken, and chop suey, besides some European salads, and bread and butter... parents find they have to make conscious efforts to keep alive the Samoan or Tongan identity in the strange land [New Zealand]. Partly that can be done by making sure the language is spoken in the home; partly it can be done by serving island dishes such as palusami (a mixed dish consisting of corned beef with taro leaves and coconut cream), taro, and fish at feasts or other community affairs. And partly it can be done by keeping alive other traditional arts and festivals at which food also features. (Pollock, 1992: 188)

Another rapped line in the lyrics of 'Soul Food' is, "my mum's sapasui is dope." As the previous quote from Pollock specifies, sapasui or chop suey is a favoured dish to have at family events and social gatherings. This is another staple in New Zealand's Samoan communities. Comparisons of who makes the best sapasui are often made: for example, at the 2015 Wellington Pasefika festival, Labour politician Paul Eagle judged a 'who can make the best sapasui' competition. Aaradhna sings the bridge and the chorus in this song,

Nothing like them meals on Sunday

I got good stuff on the way

If you're feeling like some soul food

Let me show you, how it's done the Island Way 
Every Sunday, Pacific people, particularly those that attend church, will normally attend or have to'ona'i (pronounced in the vernacular as ko'oga'i) at home, where a lot of food is shared and eaten amongst a group of people (normally family). Etymologically, the term to'ona'i refers to Aso To'ona'i, meaning Saturday, because originally the food was prepared ahead on the Saturday due to missionary prohibitions about working on Sunday. Now the food is most commonly both prepared as well as eaten on Sunday. This is seen in the lines "meals on Sunday", connecting it down to the end of the chorus saying that this is "the island way": for Pacific people, sharing a big meal together, whether at special occasions or after church, is quite an important part of Pacific culture (Pollock, 1992).

Aaradhna's unique Indian-Samoan cultural mixedness is often mentioned in promotional material, interviews and through imagery. ${ }^{8}$ Ethnic distinctions are often made in the music industry, particularly by the artists themselves, to demonstrate a sense of assertion, connectedness and pride with a group of people. They also enable the exploration of differences and alliances (Teaiwa, 2007; Zemke-White, 2002: 118). A key early example of this was in Aaradhna's first music video appearance in the collaboration with Adeaze for the song "Getting Stronger" (2004). This was her introduction into the music scene, and she wore sari material as a one-shoulder top in this video clip, coupled with plain black pants. Similar imagery of Aaradhna was also presented in the video clip for 'Down Time', the video that accompanied the first single released from her 2006 debut album. In the first scene, Aaradhna is swirling star-shaped flower petals in a bowl of water, and she's lying on a couch with green and orange sari material that has been wrapped around her and knotted at the top mid-centre of her chest. I've known some Samoan women to wear their lavalavas in such a way. Inspired by her Indian culture, her forearms are covered in gold bangles and she wears a lot of elaborate gold jewelry, as well as dangling earrings covering her

\footnotetext{
8 Tagata Pasifika music special 2013 and in her Fresh episodes, https://www.youtube.com/watch?v=uAsjLYjvp_w\&ebc=ANyPxKqn7IO8nKLMQ nk2OicbKNPR010_NjHMBnLOTQ_QSPa7zzE1NJlKf4tG97Ed8plY5VtfylDsawCk_gu qhSSv3HX1VxbFhQ
} 
ears. Other than the style in which she wears her silky fabric wrapped 'round her and the flower patterns that peek through some of the background imagery she is in front of in this video clip, there are not a lot of obviously Samoan aesthetics present.

In the 2011 Fresh TV episode she hosted, Aaradhna reveals what she loves about the Indian culture, other than the music; she makes claim to her love for the gold jewellery and the shiny fabrics of the cultural clothing. Though her forearms are not completely covered in bangles in more recent promotional photos, her love for gold jewelry is still evident, as she continues to wear elaborate dangled earrings, necklaces, and a few bangles. Gauging from her more recent performance at CreekFest 2016 in Porirua, Wellington, her signature look of shiny sari fabric wrapped round her middle is still present. At Creekfest, Aaradhna displayed a shiny orange-toned satin material wrapped round her like a lavalava paired with an off-the-shoulder black top, displaying an amalgamation of different cultural influences whilst in her home community, Porirua.

As we have seen in recent years, a range of US and Australian pop stars without Indian ancestry have worn saris with an abundance of gold jewellery and other forms of body adornment such as henna. For example, these aesthetics are displayed in the music video "Bounce" (2013) by Iggy Azalea", and most recently by Beyoncé who features in Coldplay's 2016 song, "Hymn for the Weekend."10 Both Iggy and Coldplay's music videos are set in India; this may be reason for the full Indian dress depicted by Iggy and Beyoncé. However, Chris Martin, the lead singer in Coldplay, does not display any Indian-inspired aesthetics in the music video, while Beyoncé, who is not shown physically in India (in comparison to Martin who is filmed walking the streets), is dressed in bright Indian inspired clothes, with henna on her hands, gold jewellery and a large head piece. In her music video "Bounce", Iggy Azalea does the same, dancing while she rides an

\footnotetext{
9 Iggy Azalea, (2013) "Bounce." https://www.youtube.com/watch?v=cI1A405jBqg ${ }^{10}$ Coldplay ft. Beyoncé, (2016) "Hymn for the Weekend." https://www.youtube.com/watch?v=YykjpeuMNEk
} 
elephant, but the entire ambience of the actions makes it seem superficial. Both Iggy and Beyoncé look seductively down at the camera, while adorned with these Indian aesthetics, with their hands gracefully moving in front of their faces, like an Indian dance. However, the actions and aesthetics still come off as superficial, as if capitalizing on exoticism. Aaradhna's Downtime music video, by contrast, depicts her walking the streets of her neighbourhood, looking very casual in her sari. The Indian (and Samoan) aesthetics are a reminder of Aaradhna's heritage, and their incorporation is muted in comparison to the display given by Iggy and Beyoncé.

Aaradhna's father and their Indian culture has inspired the type of music that Aaradhna has made, as well. Aaradhna's first album features the track 'Secret Lover' (2006) which is a song about two deceitful lovers. This song has a unique chorus sung in Hindi. Aaradhna commented about the song, "I knew both my cultures growing up and I really wanted to sing something in Indian for my dad" (Aaradhna, cited in Teaiwa, 2007:214).

After her second album Sweet Soul Music, Aaradhna took a break from music in direct response to the amount of negativity directed at her: "so many years I let haters take the best of me and they're the reason why I kind-of got a bit depressed, and that's why I kind-of quit music" (Aaradhna, 2013 Fresh: 3:263:37). She fell into a depression that helped influence some of the songs in her subsequent album Treble and Reverb (2012), such as the song 'I'm not the same' which is a song about her depression,

Hey Mr. Heartbreaker

You know I used to be a fighter

But ever since you came into my life

I can't find what's wrong from right

Oh you took the hope out of me

I can't find any joy in anything

And all of the things that I used to enjoy

I don't enjoy them no more 
In this song she characterises depression as "Mr Heartbreaker"; this metaphor likens depression to an unhealthy relationship that is crippling and destructive.

Aaradhna even wrote a song in response to those she characterises as 'haters'the negative commentators that contributed to her sudden decision to stop making music for a time. 'Sit with a Slouch' details the rumours and negative comments she encountered.

They say she was pregnant, they say she was fat They say she was ugly and she ain't all that She don't suit that haircut, I think she's a try-hard I don't like her music and I think she's stupid Damn, you people got so much to say I wonder if you're strong enough to take my place

As part of marketing and promotional strategies, recording artists must engage with social media, a platform where they are acknowledged for their work but also highly exposed to criticism. For public figures, entertainers and recording artists, social media is a place where an endless onslaught of people's opinions about them are expressed in less than considerate ways. This was the case for Aaradhna and, as time has passed, she has grown as a person and as a result been able to find more of her own voice despite harsh criticism. She demonstrates this in Treble and Reverb, and particularly with this song 'Sit with a Slouch,' she's showing those that put her down that it won't stop her. Speaking through the chorus of this song, Aaradhna lets people know that she will do as she wants.

I sit with a slouch, whatever I do, I do it for myself

Sit with a slouch Don't give a shit about what comes out your mouth sit with a slouch 
why should I change?

I do what feels comfortable

sit with a slouch.

Treble \& Reverb has a new and different sound to Aaradhna's previous two albums. During her break away from recording music, she went to Romania with her partner who was playing basketball there and, due to the lack of activity she was engaging in while she was overseas, she began to write music again.

Whenever Aaradhna is asked to describe her inspiration for the style of music that she produced for Treble \& Reverb, she explains that it was due to the "old school" sound she was listening to-"old school" referring to the 1950s-'60s doo-wop, rhythm and blues (R\&B), soul, funk and rock and roll artists. These included The Temptations, The Capris, Little Anthony \& The Imperials, Rosie \& The Originals, Otis Redding, and many more. She was also listening to more contemporary releases from artists such as Calvin Richardson and the late Amy Winehouse, who were similarly influenced by these "classic" artists. Therefore, when she started writing music again, it began to take on a sound very similar to these artists, and she created a YouTube channel, started writing music and uploading snippets, which thus fueled her passion and love for music and gave her the confidence to start performing and producing music again (Aaradhna, Fresh, 2013).

After Aaradhna returned from her break, she opened up and also spoke about her experience with depression-a subject that is not often spoken about. Her song 'Wake Up' was a song that she made almost as a message for herself, about her realisation that she needed to get up, and pull herself from this deep space she had found herself in. This song became quite popular in the New Zealand charts, and was her first single to reach platinum status ${ }^{11}$ (Dwyer, 2013). Aaradhna's voicing of her own experiences was important, particularly for Pacific peoples, for whom depression and other mental health issues have had

\footnotetext{
${ }^{11}$ Both gold and platinum certified singles are awarded on the basis of over-the-counter physical single sales and digital sales direct to the consumer; to gain a platinum single certificate the qualified number is 15,000 sales - http://nztop40.co.nz/about (accessed 24/02/16)
} 
detrimental consequences, particularly amongst the youth of these communities. (Ministry of Health, 2008) By having people who are in the public spotlight speaking openly about this topic, as Aaradhna does, it can encourage others to also talk about it to. This may encourage normalization of the expression of mental health issues. In an interview with Stuff.co.nz, (2013) Aaradhna expresses that music is her way of communication; it can then be used as a message for others and as a source of inspiration. Particularly for those who don't or who struggle to speak about these issues, this can provide a space where they can relate and gain confidence.

\section{Vā}

Though Aaradhna does not explicitly reference content about the vā in her music or her imagery, she is visible evidence that there is kinship between Samoan and Indian communities (Teaiwa, 2007). This is evident in Aaradhna's interviews as she demonstrates a desire to praise her parents and the influences of her Indian and Samoan mixed cultural upbringing as well as her parents' musical influences. The vā is about the space between, space that is swollen with rich meaning and a place to nurture relationships, and what she has demonstrated (in the eye of the public, from being a public figure) is that there is harmony between her and her two cultures and this may really stem from the way that her parents are with one another and how they have worked together to support their children.

This important aspect of culture is validated in Aaradhna's single "I Love You too," a song on her 2006 I Love You album. The video clip for this song is rather low budget, however it offers an insight into her home showing the viewer how much family means to Aaradhna, demonstrating the vā between her, her parents and other family members. This video follows her to her family residence in Porirua, in the Wellington region, where people are beginning to gather. Much of the focus in this video clip is around the kitchen and the making of food, as well as cutaway shots to the loving embrace that the family demonstrate when welcomed all together. A variety of food is present: a bowl filled with curry, sitting next to the bowl of taro coated in coconut cream, amongst some white 
bread for the table, meat and other various dishes-a mix of flavours from both Aaradhna's cultural heritages as well as her New Zealand context. Her siblings are present as are other members of the family, coming together in the lounge to share a meal. In this space there are photos displayed on the walls with garlands hanging from the picture frames, alternating with coconut seed necklaces and a $21^{\text {st }}$ birthday commemorative carved key that hangs alongside these.

These interior decorating touches in Aaradhna's "I love you too" video clip echo comments made by Niki Hastings-McFall in Chapter Two about her grandmother and aunt's lounge, and are familiar to many Samoans in New Zealand and beyond. New Zealand-based Samoan artist Edith Amituana'i has taken photos of Samoan lounges both in Samoa and in diasporic sites such as New Zealand and Alaska. In her Millenial series (2008) she includes the set of images "Interiors from Samoa and Alaska". Though the photos are not from a New Zealand Samoan home, like that depicted in Aaradhna's video clip, Amituana'i's photos reveal a similar aesthetic, with photos of family on the walls, decorated with synthetic lei garlands, cabinets filled with crockery, and woven mats covering the floor. Amituana'i's photographs are an intimate peek into how Samoans mix customary and contemporary-amalgamations that can affect most people, whether they are of mixed ethnic descent or not. This correlation of pictures from Samoa and Alaska to the scene in Aaradhna's family lounge, or the grandmother's lounge described by Niki Hastings-McFall, demonstrates the cultural influence that has carried from Samoa to other diasporic locations. 'To adorn' is one possible translation of the Samoan verb teu. By adorning photos of loved ones, Samoans not only beautify but also demonstrate respect for them; this is one way to physically demonstrate how one nurtures the bond and relationship-teu le vā-with those people in the photographs. It is to ensure that the relationships are kept sacred, respecting the vā and nurturing one's culture.

In the 2011 Fresh episode that Aaradhna hosted, we as the audience are able to get a glance into her world, both in her home city Porirua, in the Wellington region, and in Samoa. At her family home in Porirua, Aaradhna sits on the couch between her parents. Her father describes his influences on her musical talents and he indicates that her mother has also had an influence. Her mother speaks in 
Samoan about how she hoped that Aaradhna would sing church music, but also expresses her happiness about Aaradhna going to her village to see how her mother grew up. While in the island of Savai'i, Samoa, Aaradhna visits her grandmother and points out the photos of Aaradhna and her siblings hanging on the wall. Her grandmother expresses her joy and excitement to finally have Aaradhna there with her. Aaradhna is surprised by the wave of emotion that she experiences while being there; it's a very special moment for her. Aaradhna nurtures this connection with her maternal side of the family, and as her grandmother says in Samoan, "Aaradhna is an Indian, but she is very proud of being Samoan" (Fresh Episode, 2011). Aaradhna visiting her mother's village and spending time with her grandmother was emotional for Aaradhna, and can be viewed as nurturing this space with her Samoan relatives, and connecting with the Samoan land.

In her conference paper, "Cyberspace, place, and relationships: are we digitizing the Vā?," Cresantia Frances Koya Vaka'uta raises some of the issues that can accompany "digitizing the vā" — namely that the rules that govern the nurturing of relationships in physical place and time are not always being applied in cyberplace and cyber-time. While Koya Vaka'uta doesn't specifically go into the type of negative "hater" comments that this chapter discussed earlier in the section on Aaradhna's battle with depression, I think these can usefully be understood as examples of Koya Vaka'uta's argument about the re-negotiated "acceptable" boundaries in cyberspace. Because of the degree of anonymity afforded by the internet, the rules of engagement online are not always respected the same as they would be if in physical place and time. This has resulted in new phenomena like "keyboard warriors" and cyberbullying. Koya Vaka'uta asks, "What are the power-relations that drive this space? Is there room to teu le va without losing ourselves to the matrix completely?" (Koya Vaka'uta, 2012: 5). In the case of Aaradhna, she battled with depression because of her vulnerability to the digitised sphere where critics in this space did not "teu le vā". 


\section{Chapter Five: Comparison Chapter}

This chapter comparatively analyses the works of Niki Hastings-McFall, Grace Taylor and Aaradhna Patel, drawing on the concepts of tauhi vā and teu le vā to explore and compare how-through their work and public commentary-these artists actively articulate and maintain their cultural connections and engagement with the various aspects of their multi-ethnic identities.

Past comparative research has shown that a better understanding of mixedness can be gained when comparing work of more than one artist. (Fatu, 2013). Comparing different genres of art may also offer additional insight that otherwise may not have come to the fore. This thesis research was able to discover similarities between each artist, while also discovering various differences that helped to enrich the analysis, supplying a better understanding of the nuances of how people identify with and express mixed heritage in New Zealand. This thesis has drawn upon information from secondary sources and from the artists' own writings, interview material, recordings and biographical information, in addition to my own perspective and analysis of their art, to gain a better understanding of how these artists shape their identities.

Grace Taylor and Niki Hastings-McFall are both of European and Samoan descent and based in Auckland, however they are from different generations. While Taylor was aware of both her ethnic backgrounds, Hastings-McFall was raised believing her British grandparents were her parents and was initially unaware of her Samoan heritage. Knowledge of her Samoan culture was denied to her as a child, and it wasn't until she was in her adult years that she independently decided to locate and make contact with her Samoan father and Samoan relatives. On one occasion, when Hastings-McFall went to visit her aunty (her father's sister), she saw a photo album with her baby pictures in it. Back when Hastings-McFall was still a baby her father and his sister would meet HastingsMcFall's mother in secret so he could see them. Contact between Hastings- 
McFall's mother and father came to an end once she was officially adopted by her grandparents, something that Hastings-McFall assumes was a condition laid down by her grandparents in order to keep her in the family. Hastings-McFall has half siblings on her father's side but she was always considered the eldest child (Hastings-McFall, interview material 2016).

Literature on Hastings-McFall often mentions the late encounter with her father as an important milestone in her life (Mallon \& Pereira, 1997; 2002; Stevenson, 2008; Pasifika Styles, 2013). Since meeting her Samoan extended family, Hastings-McFall has done a thorough amount of research about the Pacific region and its history, sparking an interest and passion that resulted in Pacific influences becoming more visibly present in her art. Hastings-McFall draws inspiration from Samoan history, as well as iconic symbolism such as the synthetic flower lei (directly influenced from the first encounter with her Samoan family), which is now a recurring icon in her visual art.

In comparison, Taylor came from a single parent family, raised predominantly by her Samoan mother. This is very different from the experience of HastingsMcFall, for whom the Samoan parent was absent from her childhood. Despite Taylors parents' separation, she would have been aware of her dual heritage whilst growing up. Taylor also comes from South Auckland, an area that has a large concentration of Pacific people; she would've certainly faced more pressure to live up to people's expectations about "correct" Samoan behavior. Although Hastings-McFall is also from Auckland, her experience in Titirangi was quite different and she recalls that she didn't encounter many moments of seeing brown faces in her community growing up. (Hastings-McFall, interview material, 2016).

Thus, whilst Hastings-McFall was being denied her Samoan heritage during her youth, Taylor felt she needed to prove it. In earlier discussions in Chapter Three, Taylor often spoke about the fairness of her skin and how she had an issue with the stereotypes that were associated with this, 


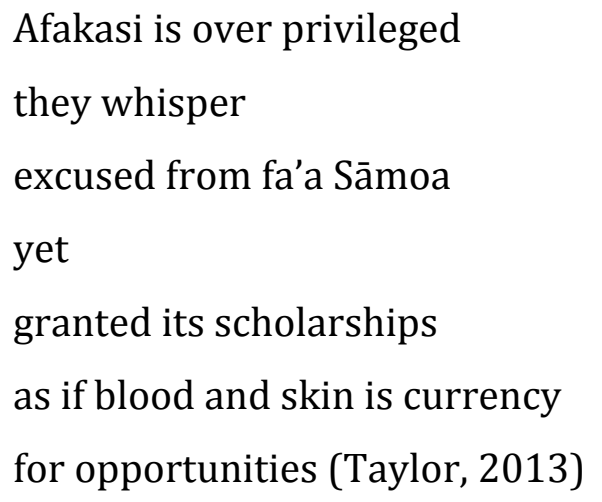

The lines above are from Taylor's poem, "What is afakasi” (see appendix B, poem 1); rather than relaying Taylor's own viewpoint, these lines express how others view experiences of 'afakasi. I found the line "excused from fa'a Sāmoa" interesting because this, to me, means being excused from the Samoan way and the many cultural mores and actions that are part of fa'a Samoa such as the ones discussed by Lilomaiava-Doktor in Chapter One. The disapproving tone conveyed in this verse implies that this is something that Taylor wouldn't like to happen based on skin tone.

Articulating a different perspective on cultural obligation, Hastings-McFall, expresses how she feels she doesn't necessarily need to do the fa'a Samoa thing, and she relishes the ways her 'in-betweenness' releases her from expectations. In interview material, Hastings-McFall talks about the vā and how she's content with being in-between,

For me the vā is the space between, which is kind of a nice metaphor for where I feel I stand in terms of culture and society and stuff like that. You know it's that liminal space where you can (you know like the Venn diagram) float in and out and never be entirely one thing or the other, but then that gives you freedom to be whatever you want. So that means that I don't have to do the "Samoan thing", with going to church, being a good girl, getting married to a nice Samoan boy and all that stuff. When I go to my family things I don't go and sit with the women and talk about babies, I go out the back and drink beer with the 
guys...it's almost like defining myself from the point of view of not being Samoan, (Hastings-McFall, interview material, 2016).

Hastings-McFall finds it liberating being in-between. It was one of the greatest turning points for her to meet her Samoan family. However, initially being denied knowledge of her Samoan heritage, and not being brought up with Samoan customs and values, are not things that Hastings-McFall seems to dwell on negatively. She is able to make definitive decisions about what she does and how she acts. She values the vā between her and her Samoan family and demonstrates teu le vā by being present and learning about her culture while also remaining true to herself. Hastings-McFall continues to be spontaneous and care free and does not let restrictive ideals define who she is and what she does in life.

Taylor had been exposed to Samoan culture, however she didn't necessarily feel like she looked Samoan, which was an issue she personally faced that she explored often in her poetry. Now she feels that being in-between is also a way for her to nurture the vā between her and her parents, and her different lineages. Taylor and Hastings-McFall's differences in age, upbringing, and the contrasting demographics of the communities in which they were raised have influenced their respective holistic formation and shaped the creative cognition by which they express their art form and themselves.

In contrast to Taylor and Hastings-McFall, Aaradhna had an upbringing with both parents present in her life, and was provided with the knowledge of both sides of her ethnic heritage. Aaradhna is of Indian and Samoan descent, both of which are minority groups in New Zealand. Research by Sam Manuela and Chris G. Sibley (2012), discussed in Chapter One, outlined possible reasons why mixed Pacific people that identify with both a minority group as well as a majority group were more likely to express lower levels of self-esteem when compared to those that were monoethnic. Their study suggested that, as a result of the broader society's lower levels of warmth towards their minority group, it led them to feel conflicted within themselves. In Chapter One, I contrasted these 
findings with the counter example from (Anae, 2010), questioning the basis of their arguments. However, I also propose that Manuel and Sibley's findings may be different from the experiences of those that identify with two or more minority groups (rather than a majority and minority group). Aaradhna grew up in Porirua, an area of Wellington with a large number of Pacific people who are very accepting towards her Indian father, who was treated like another Pasifika person in the community.

In most interviews analysed for this thesis, Aaradhna has mentioned her ethnic background (Aotearoa Social Club, 2012; Grindin, 2013; Oliver, 2015; Aaradhna FRESH TV 2011 \& 2013; Aaradhna, 2013; Bureau, 2013; New Zealand Herald, 2013; Tagata Pasifika, 2013; Tapaleao, 2014; YouKnow IGotSoul, (2013). Teaiwa (2007) elaborates on this phenomenon, discussing that when Aaradhna began her singing career, people questioned out of curiosity what her ethnicity was. Teaiwa suggests that Aaradhna would always mention her heritage to deter confusion and aid some explanation about her cultural appearance. In all her promotional materials, she speaks highly of her parents, how they brought her up and the influences they had on her musically.

Choosing a comparative lens has been particularly useful in demonstrating how mixed Pacific identity is experienced differently for everyone, even if mixes are the same. The environment in which we live, the people who raised us, our levels and types of education, and all other factors that have influenced our upbringing and personal development through life, will influence and shape the identities that we take throughout our journey.

\section{Medium}

The most obvious difference with these three artists is that they specialise in different mediums. As a multimedia visual artist Hastings-McFall's work appears the most different in comparison to Taylor and Aaradhna. Commonalities found between Aaradhna and Taylor lie within the area of creative expression through vocally-delivered text. Aaradhna writes music lyrics that can be understood as a 
form of poetry writing and both of these artists also have a performance element as part of their craft. For example, through the art of spoken word poetry, Taylor is constantly 'performing' her poems. The act of performing does not just consist of her going up on stage and reciting what she has written down; her delivery of well-memorised poems has to effectively incorporate movement, and tone variation, in order to involve and engage with the audience.

In comparison, Aaradhna is a musical artist and as part of this she has to entertain her audience in a similar fashion to how Taylor captures her audience's attention. As a performer, Aaradhna similarly has to have great stage presence by using movement, face expressions, having heart in what she sings and involving her audience. This was something that she needed to practice early on: when she was less experienced, she recalls getting up on stage and just standing like a tree-singing but not moving. She was told that she had to move, to engage with the audience-to give her performance life-so that her music is believed and felt. (Oliver, 2015)

In contrast, Hastings-McFall is quite different in this sense; she creates pieces of work that may have a brief description to aid in their interpretation, but generally the work is left to speak for itself. She cannot possibly be there in person while people visit her exhibitions daily, and there is no audio attached to every piece of art that she creates. While Grace Taylor's poetry and Aaradhna Patel's lyrics are also open to interpretation, the nature of visual art-which can be uncoupled from any accompanying text—gives it a greater degree of openness.

In any art form there is an element of open interpretation. In poetry, poets have a measure of freedom to write whatever they want to, whatever the poet may be feeling. Taylor purposely wanted to craft and perform poems about topics that people don't often speak about, taboo subjects. Comparatively, the commercial music industry may possibly be more restrictive in some ways, as it's a business after all. Sometimes artists will create music that appeals to certain audiences for the purposes of commerce. However there is still a lot of personal expression 
coming through Aaradhna's music, particularly her more recent material where she expresses times that she was vulnerable. This has the ability to also appeal to an audience, as it can offer a feeling of genuineness and relatability.

Aaradhna, being a popular music performer, is more likely to face praise as well as negativity from her audiences, which unfortunately comes with the territory of being a public figure and performer. I interpret her public image as being crafted quite deliberately to highlight her ethnic mixedness. For instance, she has amazing custom tattoos on both her hands that are an amalgamation of visual elements from both her Indian and Samoan heritages. The location of the tattoos makes them very difficult to hide. The tattoos make a very bold statement and are clearly something that Aaradhna intends for people to see.

Also worth mentioning is that Aaradhna is the oldest of five. So she had four younger siblings to grow with, and I think that her family play a huge role in her life. Her room back at her parent's place is where she gets inspiration to write music; much of the new material that she produces was imagined and created in that room, at home (Aaradhna, Fresh episode, 2011) So home and family seem to be things that were grounding for Aaradhna. Particularly considering how commentators in the broader society and their online critiques were not always kind to her, Aaradhna's ability to depend on intimate relationships with her partner and her family has played an essential role in her continued production as an artist.

\section{Themes}

Taylor has written and performed spoken word poetry around 'afakasi identity. Aaradhna and Taylor both have experienced the impacts of outside scrutiny: for Aaradhna, these caused her to temporarily give up her singing career, whereas Taylor was able to channel her feelings through her poetry. Now Taylor has embraced her 'afakasi identity and it will always be part of her and therefore will be present in whatever she does as an artist, an identity that is one amongst her many (mother, poet, daughter). 
Aaradhna does not often lyrically describe the cultural influences that she has had, but they are amply referenced in interview material and also present in her imagery, particularly her earlier video clips of songs on her first album that aesthetically showed representations of both her Samoan and Indian heritages, with gold bangles covering her forearms and sari material wrapped around her, worn like a lavalava. Aaradhna's music at present is strongly influenced by African-American music of the 1950s and '60s and she's still known as an Indian and Samoan R\&B soul diva. Hastings-McFall is a prominent and recognized Pacific artist in New Zealand and she continues to create artwork that has Pacific themes. She often explores the urban contemporary environment alongside the ancient material and philosophical culture of the Pacific in her work, an area that she demonstrates much passion for, though she's constantly having to learn through her own research and interpretation.

\section{Vā}

This thesis looks at the idea of vā and the concept of teu le vā or tauhi vāmeaning to nurture relationships (Anae, 2010; Ka'ili, 2008). Mentioned in Chapter One, Tevita O. Ka'ili practiced tauhi vā while in Maui by establishing connections to people and places, tracing back his genealogy whenever he encountered another Tongan. In New Zealand, Pacific peoples (mixed or otherwise) daily negotiate "ambivalent kinships" (Teaiwa \& Mallon, 2005), drawing relationships and connections between themselves and Māori, Europeans and different generations of Pasifika. I believe that the creative areas that Hastings-McFall, Taylor and Aaradhna occupy perform tauhi vā in their own way because they create connections with those that appreciate their art while also raising social consciousness (Wilson, 2013).

Taylor uses poetry and theatre as a space of political activism and expression around social subjective issues in New Zealand's society particularly amongst Pasifika youth. Taylor raises attention to subjects that are often left unspoken, by doing so this creates a relatable space where others are able to draw a 
connection with her as well as with her poetry: "scatter me among yourselves / and use me / to fill the gaps" (Taylor, 2013) (refer to Appendix B). Interpreting this quote, Taylor is constantly reaching out to youth and those that are most vulnerable whilst they discover who they are. As a previous youth worker, as well as a teaching poet, and mentor, she is constantly "scattering herself" to mentor those that need guidance to fill the gaps.

Explored in greater depth in Chapter Three, Taylor will often push boundaries. Similarly, Aaradhna has expressed through her music moments of her life where she was most vulnerable. As with Taylor's poetry, these moments that Aaradhna has captured can be very relatable topics, particularly for Pacific (and other) youth. An example of this personal expression is in her song "Wake up" (2013) from her album Treble and Reverb, a track almost sung to herself when she realised that she was at a standstill and life was passing her by. Another example is the song "I'm not the same" (2013), a song about her crushing wave of depression after she quit music.

In the era that we live in there is unfortunately a danger in online social spaces. Because of online anonymity, the rules of engagement online are not respected the same as they would be if in person. As explored in Chapter Four, the vā is being re-negotiated within the sphere of cyberspace (Koya Vakauta, 2012). This can pose challenges for Pacific people for whom cyber-mediated relationships are both increasingly important but also, in an era of "keyboard warriors" and cyberbullying, sometimes difficult to manage effectively. This creates very real mental and emotional strain, particularly for many Pacific youth.

Tamasese et al (2005) illustrates how maintaining healthy, respectful relationships-good vā-is vital in support of those suffering mental health issues. However, because mental health is something so personal, happening within the person, I also believe that it is vital for people to have nurtured a good healthy relationship with themselves. When Taylor began to move beyond struggling with her identity, it was when she began to appreciate both sides of her heritage. The poem "Afakasi intertwined" narrates Taylor's identity struggle, 
but by the end she has come to the conclusion that she needs to accept herself. In "I am the vā" she speaks about not wanting to cause "disruption" between both sides of her heritage. As discussed earlier in Chapter Three, when Taylor was younger she wanted to look brown, and then later felt she was discrediting her European heritage. She now has moved on to other topics in her poetry but her 'afakasi identity is still with her.

As for Aaradhna, the sense of emotional and mental dissonance didn't occur from self-conflict about her dual heritage, but was caused by outside critics, particularly in the realm of social media. Aaradhna temporarily stopped her music career because of her battle with depression and her vulnerability to a digitised sphere where people can easily choose not to "teu le vā" because of the anonymity of the internet. Aaradhna and Taylor will be more likely than Niki Hastings-McFall to be exposed to this form of attention because their art forms appeal more to the youth that are so engaged in this online platform.

Hastings-McFall has always found the beauty of being in the in-between, not being wholly of anything; this is a quality she explores in most of her work. In her "Polynisation" (2005) series, the European objects can be interpreted as symbolizing her European upbringing and foundations, which are now smothered with the knowledge she has gained about her Samoan culture and Pacific history. Her own hybridity is shown in this piece, and as it is aesthetically pleasing the message from this series can be particularly relatable to many Pacific people in New Zealand. As literature suggests, it is important to respect and nurture vā, which is why actions to tauhi vā and teu le vā are so vital in practice to care for relationships. Hastings-McFall has come to an understanding that she is not one whole of anything in regards to culture; she sees her duality as a positive way to be. As Whimp relays, she refers to herself as "one of the everincreasing multicultural breed of New Zealanders evolving in the late twentieth century Pacific with a personal interest in exploring the concepts of ethnic hybridity" (Whimp, 2009: 15). It is difficult to tauhi vā with others if you have inner turmoil; therefore it is important to tauhi vā within yourself. This is what 
Hastings-McFall does as she explores both her dual ethnicities and other values that she centres in her work. 


\section{Epilogue}

Like a sensitive plant, the artist, through an unconscious process of osmosis, draws his mana (his artistic and imaginative energy) from everything surrounding him like a birth sac, from different sources - the aesthetic and cultural traditions into which he is born, his personal relationships, even the food and drink he consumes, and so forth. This mana transmits back into his community in a reconstituted form. How well he does this depends on his talents and the ability of his society to receive his painting, or poem, or song, or whatsoever form he had encapsulated his mana in. Factors such as censorship, the reaction of critics and those who control his community and the art market, and the need to earn a living can influence; hamper, and even stop that transmission (Wendt, 1978: 107)

The artists at the centre of this thesis have inspired and taught me many things. They have demonstrated how their mixedness, their surroundings, and other people's opinions have influenced their artistic expression and shaped them into stronger people.

As part of her artistic practice, Niki Hastings-McFall will think through a concept or idea and then make it come to life in visually pleasing aesthetic installations. Often drawing from her environment and dual ethnic heritage, she combines the urban contemporary with the historic or ancient, and the Pacific with the European. Hastings-McFall feels comfortable in the space between, not fully whole of anything. Because of the creative space that she works in she is able to be creative, fun and witty while simultaneously addressing serious topics, such as colonisation in the Pacific, Pacific navigation, religion, references from Pacific and European art history, and themes of death, love and loss. 
Grace Taylor explored her mixedness quite explicitly and deliberately in poetry published and performed for the public. The poetry in "Afakasi Speaks" (2013) placed her mixedness at the forefront of her art, exposing her soul to the realm of vā/tauhi vā, creating poetry that has been relatable to so many others. Taylor uses poetry, and more recently theatre, to highlight her experiences of Pacific mixed identity and other personal aspects of her life, like being a single mother. Taylor's experiences connect to my own in terms of being subjected to racial discourse of skin colour and identity and some of the harsh realities that many people of mixed race face.

Aaradhna has always embraced her dual heritage in the public eye, and did not seem to struggle with her mixedness. Instead, she underwent other forms of public scrutiny from audience listeners/watchers, which became detrimental for her wellbeing. However she learned from this experience and she doesn't let criticism affect her the same way now.

In this thesis, the concept of vā has helped explore how art can offer accommodating spaces for expressing identity, but also space where many issues can be explored, regardless of politics, taboo or social reservations. The Polynesian concept of vā characterises the bridge between ourselves and that to which we are trying to connect. This means that artists that work this space are able to express their relationships, with people, the environment, with their religions as well as the relationship with themselves. This can offer a liberating space for others to think, imagine and possibly explore their relationshipsnegotiate their vā.

In the concluding weeks of my research, I was asked by a father of Pacific heritage if I was Samoan, and I replied, yes, I am half. He followed with the question, “Do you speak Samoan?" Without any hesitation I replied, no. He looked at me shook his head a little and began to tell me about his daughter who is New Zealand-born but speaks fluent Samoan. Previous to this research, this conversation would have affected me, making me feel lesser of a Pacific Islander because of my inability to reach expectations of others. However, due to the 
extensive research I have undertaken, and remembering the journeys of the artists that I have explored, I was able to conceptualise why he asked me this question. Perhaps he wanted to teu le vā with me in Samoan, just as Ka'ili did in Tongan with the other Tongans he encountered in Maui. My personal placement of being in-between means that I am more than happy to teu le vā... in English. In that very moment, I was able to just 'be' regardless of attitudes or challenges of authenticity. In that moment the space "in between" seemed just 'sweet' for me.

As Albert Wendt (1976: 85) so eloquently assesses, "In their individual journeys into the void, these artists, through their work, are explaining us to ourselves and creating a new Oceania". 


\section{Appendix A:}

Figure 1. Too much sushi lei

http://collections.tepapa.govt.nz/object/531842

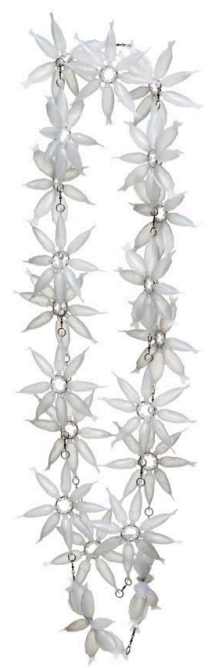

Figure 2. Dangerous Curves (Red), Urban Navigator Series, 2001 https://artcollection.auckland.ac.nz/record/69124

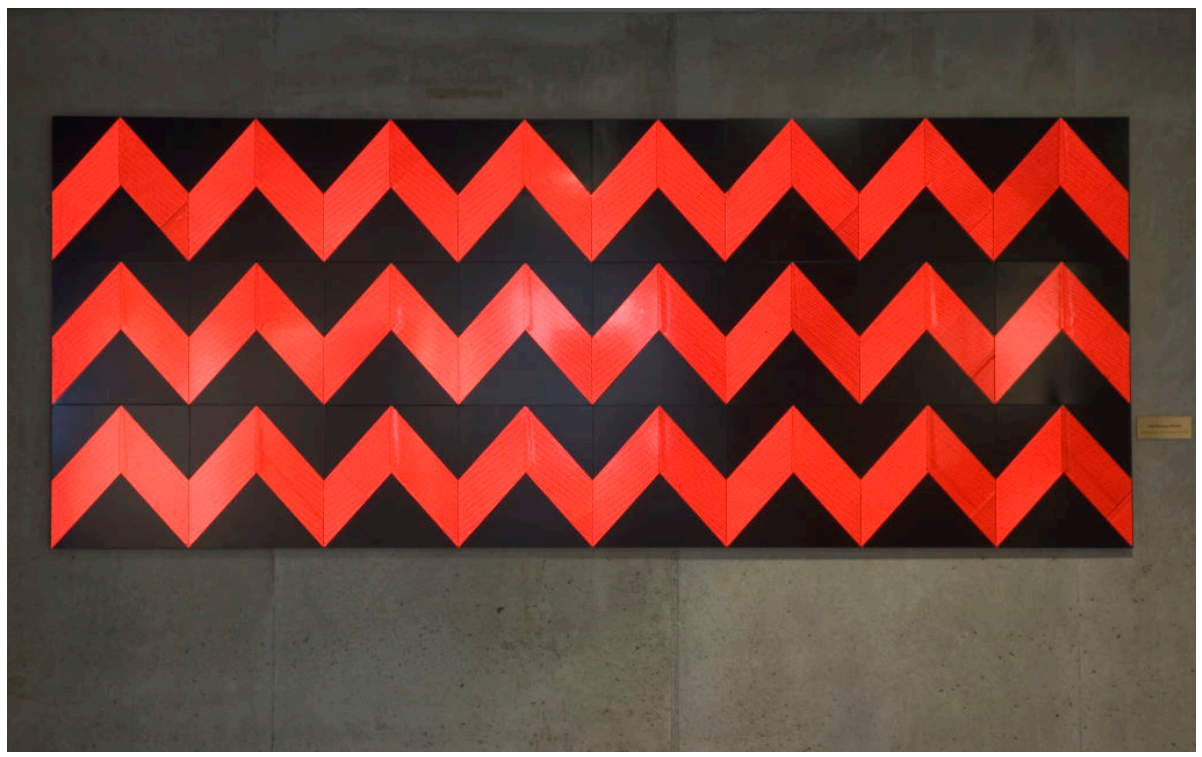

Figure 3. Flock, Urban Navigator Series, 2001. 
http://www.whitespace.co.nz/artists/niki-hastings-mcfall.aspx

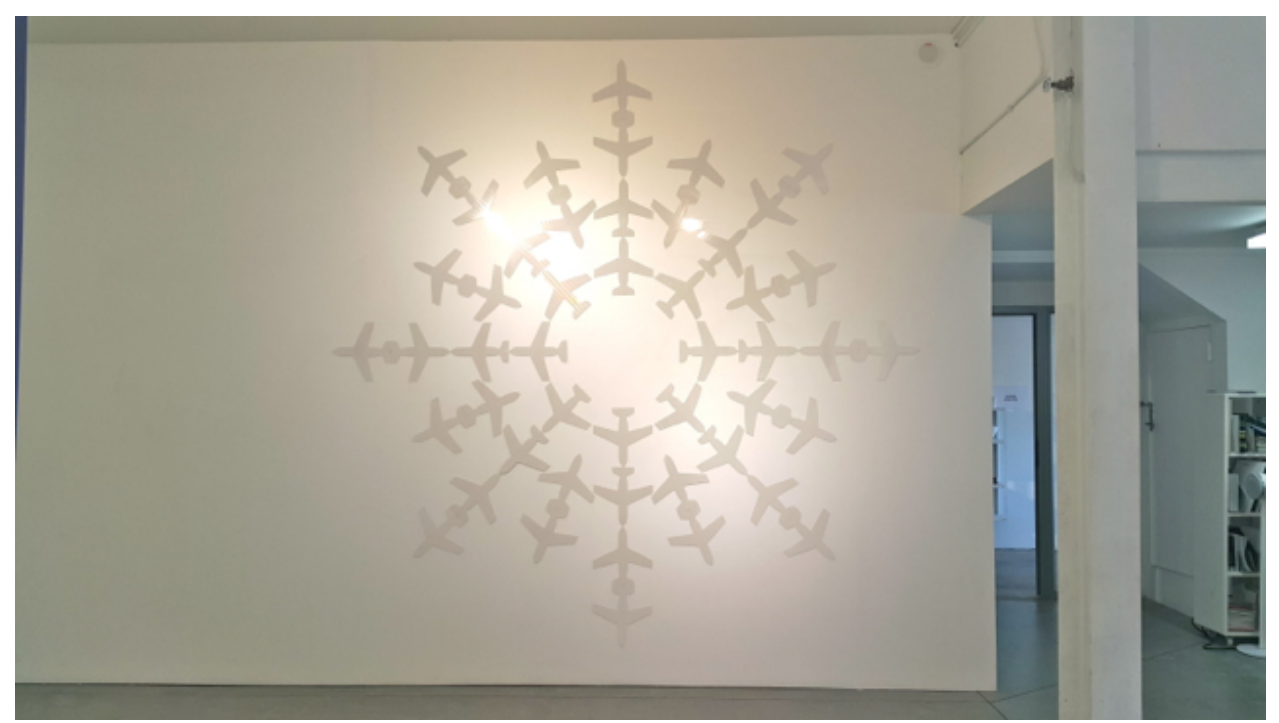

Figure 4. Polynisation Series, 2005

http://www.whitespace.co.nz/artists/niki-hastings-mcfall.aspx

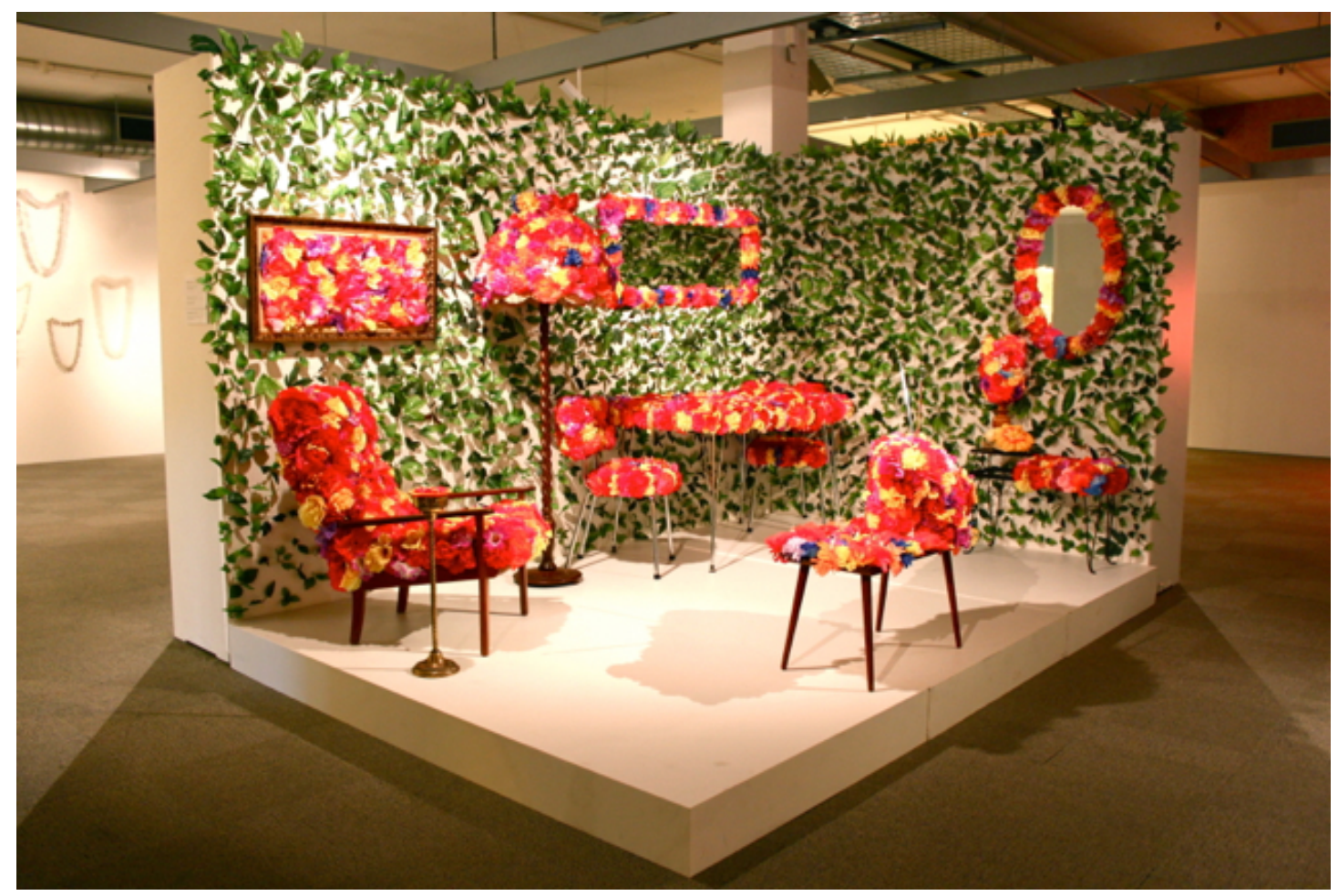


Figure 5. Have a Little Faith, Swansong, 2009.

http://www.milfordgalleries.co.nz/artwork/1289-Swansong-2009

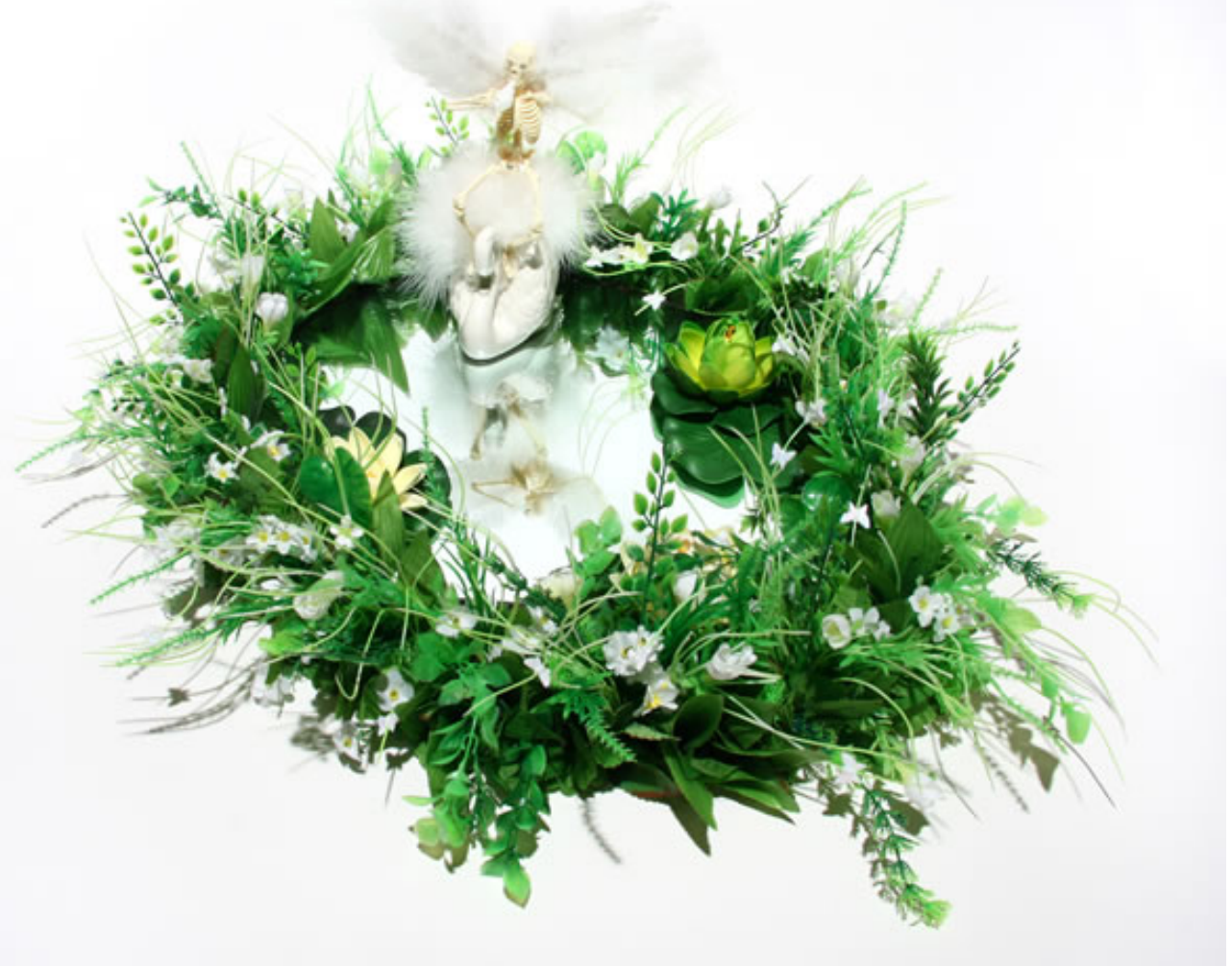

Figure 6: Long While Cloud, 2012.

http://www.tautai.org/artist/niki-hastings-mcfall/

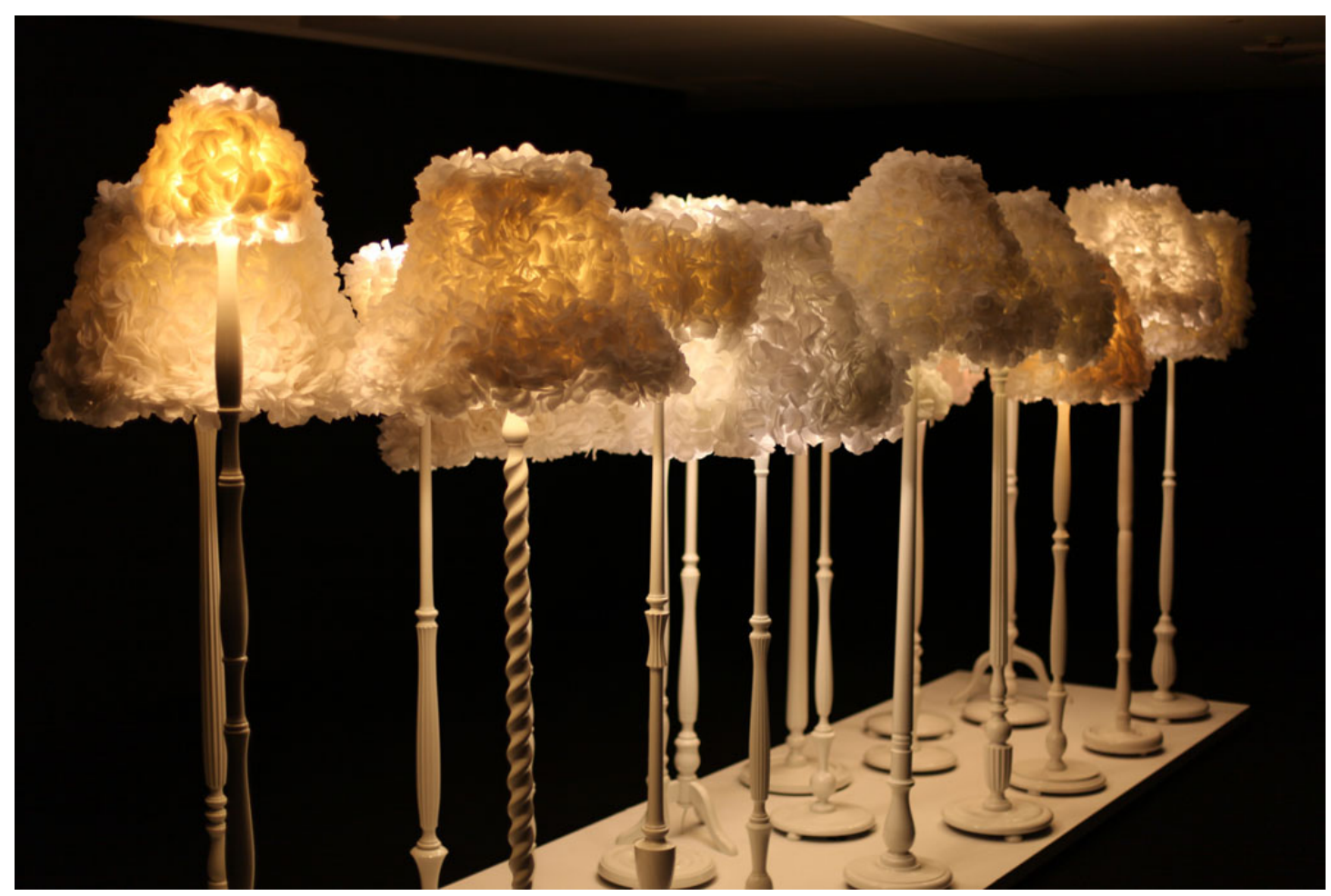




\section{Appendix B}

\section{Poem 1.}

\section{What is afakasi?}

You ask

What is Afakasi?

Afakasi is dead

They once said

and it was almost like

I could see your hues getting lighter

blending into one

corners that have been stretched

no longer fit you

confined in your redefinitions of identity

Afakasi where are you from?

She asks

I've never heard of your land

shifting Afakasi to a place like Polutu

implying

my sense of belonging

can only inhabit one place

Eh, Afakasi, are you saying you are a new race?

In between is too hard

you once said

It's not easy being disruption

the cultural eruption

that causes people

to umm and aahh

question and hesitate

Afakasi is part

dying and living

resenting and forgiving

wrong and right

surrender and fight

here nor there

white skin untamable hair

you can never fake

that you don't care

Afakasi is running a race

you once said

races against races

where are we placed? 
First, second or third?

But I see race beside a race

to a finish line

that will challenge minds

Afakasi is overprivileged

they whisper

excused from fa'a Sāmoa

yet

granted its scholarships

as if blood and skin is currency

for opportunities

Afakasi is hybrid

they said

as if we are scientifically designed

injected

synthetic

realigned

into an unnatural state of being

I'm Alive!

I'm Afakasi-stein

as if

the Creators hand-gathered us from dust

and placed us

in no-man's land

Afakasi is cut up

dissected

into red-stained quantums

of halves and quarters

measured, defined, redefined

celebrated

then

Shut Up!!!

Coz

Afakasi has no right

to speak on full blooded affairs

your skin is too fair!

As if

full-blood is more red

pumping

a heart to speak

Afakasi is prized

I've heard him say

I want Afakasi children

as if 
they are a rarity

a delicacy

100 paces back

to mindsets

of Gauguin cooking fantasies

in a melting pot

of naked breasts

long island hair

a hibiscus behind the ear

Afakasi is inked up

the tap-tap tap-tap

bleeding the brown

to the surface

creating maps of heritage

a badge of ancestry

Afakasi is redundant

you said

your evolution in terminology

discrediting my whole history of identity

all I've ever known is this

holding onto this term

with a tight fist

no more Afakasi

must mean

I don't exist

But

Afakasi is my generation

a product of your migration

she feels

that is how I know she is real

she can't be dead

she lives

in me, you, half the generation

in my neighbourhood

She breathes

she changes

chameleon-like

she's not dead

she evolves

into representations of

stories

struggles 
hopes

dreams

Half-caste

smashing casts

moulds constructed by others

casting shadows

on taboo territories

you can't talk about that realities

cast out

out cast

thinks

moves fast

looks past

Colour!

White father

Brown mother

So you ask,

What does Afakasi mean to me?

Afakasi is all encompassing

a compass reclaiming

explaining

identity

divorced from colonial chains

reclaimed to set free

Afakasi is not

dead

a hard... part... race

privileged... hybrids

cutting up

rights with

prized

ink-made

redundant

She is

breathing

changing

evolving

smashing

whispers kissing microphones

amplifying tones 
Afakasi speaks

and she is heard

\section{Poem 2.}

\section{Am the Va}

Va is the space between, the between-ness, not empty space, not space that separates but space that relates, that holds separate entities and things together in the Unity-that-is-All, the space that is context, giving meaning to things.

-Albert Wendt

I am the va

scatter me among yourselves

so cut me up

of the space between

and tastes the bitter sweetness

and

brown

Mud

white

slap some colour onto us

that is how some have treated us cleanse culture into our pigments

as if skin soldiers

invaded white into us

and we just let them

mud reveals

But when the rain and dirt swim

worms

U and Polu

that can unearth stories

that feed on decayed histories

between life and death.

the va

to condemn and stone the other side of me

You want me to choose making me believe one half is a victim

that bonds my two halves

to separate the marriage of bloodied ropes

so thin we

to create a twisted tight tension

disrupt the va

SNAP

You want to be my Patriarch

between mother and father. 
bestowed by your $100 \%$

of cultural authority

your rose between the cracks

create a va

My va

nor there

nor white

and exists in everything.

between ignorance and acceptance.

scatter me among yourselves

to fill the gaps

\section{Poem 3.}

\section{Intertwined : Being 'Afa Kasi}

English roses

snow blooded lines

Samoan tattoo

coco blooded lines

intertwined

created by the love of two

under the One

makes me.

This white skin

nurtured in a brown community

struggling to find unity

within me.

Bouncing from one skin to the next putting my culture on to fit in with the rest fighting to not be the miniority in a vain attempt to have them accept me.

Even within my own family

RACISIM to instill your superior lineage making me your kingdom your jewel in the rough watered down cultures between knowing and being unknown. is neither here not brown it belongs in nothing I am the space So cut me up and use me 
spoken from the mouths of my own blood

saying it as a joke?

saying it with love?

No!

Don't be so nieve to think

I don't know it's about me you speak.

"Uummm teine palangi"

sideways looks and laughing light

exempt from feaus

making me feel whiter then white.

and

"I hear her mum is Sar - mo - win?"

has darker skin?

Damn, now I be shocking.

Friends

"Who Grace? She's afa kasi man, hamo hard"

as if it were to excuse my lighter shade?

but I started it didn't I?

'I'm half Samoan'

say it loud

say it proud

Feeling I gotta be a little louder

Speak a little browner

I like taro and coconut cream

Palusami and kokoalaisa

Wearing my lavalava as my island dressing gown

Laughing at someone when they tripped and fell down

What I gotta do to prove

I'm just as Samoan as you?

What, you think it's the colour of my skin?

the words I be speakin?

clothes I be wearin?

that whispers. . .racism

Then again,

I remember wanting my mum around me

as if she were a ticket

to prove I'm from the Polynesian family

now who's whispering racism?

Why is it so hard to others to see

Others to believe

The mixed flavours of me

I guess it had to start with

ME 
Yes, racism

from family and friends, but my journey revealed

"damn Grace, it's also from within"

Why can't we choose to be colourblind?

instead of allowing our colour to blind

our vision

of who someone truly is

what they nurture, what they give

Identity

gotta find

I found in

Divine

His love is colour blind

your blood flows the same as mine

And yeah, I'm still learning my culture and identity

but I feel what you feel, also within me

when that island drum beats

it makes my heart beat

words from my land

to my heart it does speak

My blessed island curves

in this white skin

My English words

wrapped in humour that is undeniably Polynesian

It's all one in the same

it's 'Afa Kasi

the name itself acknowledges

a journey

a struggle

a celebration

a life

being 'Afa Kasi

ME! 


\section{Bibliography}

Aaradhna. (2006). I Love You. New Zealand: Dawn Raid Entertainment.

Aaradhna. (2008). Sweet Soul Music. New Zealand: Dawn Raid Entertainment.

Aaradhna. (2012). Treble \& Reverb. New Zealand: Dawn Raid Entertainment.

Aaradhna. [Idolator]. (2013, Jul 27). Aaradhna: Popping up. [Video File]. Retrieved from https://www.youtube.com/watch?v=RPD3aJbPMIE accessed 30/03/16.

Aaradhna. [KITV]. (2014, Apr 24). Aaradhna's Hawaii Tour 2014. [Video File]. Retrieved from https://www.youtube.com/watch?v=DcdUlrrVTig accessed 30/03/16.

Aaradhna (2016) Aaradhna- A Cup of home... [Instagram] Retrieved from: https://www.instagram.com/p/BC_-Hx5nFQJ/?taken-by=aaradhna\&hl=en accessed 30/03/16.

Action Education, (2015), Spoken Word Guidelines: A Best Practice Guide for Educators. http://www.actioneducation.co.nz/uploads/2/9/8/1/29818351/spoken_word_ guideline_lo_res.pdf accessed 20/02/16.

Adams, M., Brunt, P. W., Mallon, S., Thomas, N. (2010) Tatau : Samoan tattoo, New Zealand art, global culture Wellington, Te Papa Press.

Adeaze (2004) Getting Stronger [Recorded by Adeaze feat Aaradhna] on Always and for Real [CD], New Zealand, Dawn Raid Entertainment.

Anae, M. (1997). "Towards a NZ-born Samoan identity: some reflections on 'labels'." Pacific Health Dialog, 4: 128-137.

Anae, M. (1998) Fofoa-I-Vao-'Ese: The Identity Journeys Of NZ-Born Samoans (PhD Thesis). University of Auckland, New Zealand.

Anae, M. (2010). "Research for better Pacific schooling in New Zealand: Teu le va- a Samoan perspective." Mai Review 1: 1-24.

Ang, Ien. "Diaspora." In Bennett, Tony, Lawrence Grossberg and Meaghan Morris, eds, New Keywords: A Revised Vocabulary of Culture and Society. London: Blackwell, 2005: 82-84.

Aotearoa Social Club. (2012, Nov 23). Singer Aaradhna studio guest on Aotearoa Social Club late night talk show. [Video File]. Retrieved from https://www.youtube.com/watch?v=fbQJtQ-zpLY accessed 29/03/16. 
Asian Society Museum (2004) Paradise now?: contemporary art from the Pacific: 2004. http://www.asianart.com/exhibitions/paradise/index.html\#10 accessed 30/03/16.

Azelea, I., Reeva., Black,. Speedy, J., Riley, T., Olatunji, O., Sims, N., (2013) Bounce [Recorded by Iggy Azalea] On The New Classic [Single] London, Virgin EMI.

Bennett, T., Grossberg, L., Morris, M., \& Williams, R. (2005). New keywords: A revised vocabulary of culture and society. Malden, MA: Blackwell Pub.

Berryman, G., Buckle, J., Champion, W., Martin, C., [2015] "Hymn for the Weekend" [Recorded by Coldplay feat Beyonce] on A Head Full of Dreams [Single] London, Parlophone.

Bhabha, H. K. (1994). The location of culture. New York: Routledge.

BNZ. (2014). Diversity delivers a distinct competitive advantage.

https://www.bnzcareers.co.nz/pdfs/BNZ-Diversity-Case-Study.pdf accessed 09/03/2016.

Bolatagici, T. (2004). Claiming the $(\mathrm{N})$ either/(N) or of 'Third Space':(re) presenting hybrid identity and the embodiment of mixed race. Journal of intercultural studies, 25(1),:75-85.

Breast Cancer Foundation NZ (2011, Sep 29) Save Seven- Niki's Story [Video File] retrieved from https://www.youtube.com/watch?v=00EXX_YDXzI accessed 20/04/18.

Brotha D (2007) Soul Food [Recorded by Mareko feat Baby Down (Brownzville) \& Aaradhna] On Element of Surprise [CD]. New Zealand; Dawn Raid Entertainment.

Brunt, P. W., Thomas, N., Mallon, S., Bolton, L., Brown, D., Skinner, D., \& Küchler, S. (2012). Art in Oceania: a new history. London: Thames \& Hudson.

Bureau, I. (2013). "Beyond 20 questions with Aaradhna Patel”. Indian Weekender: Pulse of the Kiwi Indian community.

http://www.indianweekender.co.nz/Pages/ArticleDetails/7/3768/NewZealand/Beyond-20-questions-with-Aaradhna-Patel accessed 10/09/15.

Calvet, Louis-Jean 1994 La Voix de la Ville: Introduction à la Sociolinguistique Urbaine. Paris: Payot: 28-29.

Capital Life (2013) The only way is up. Retrieved from http://www.stuff.co.nz/dominion-post/capital-life/8828569/The-only-way-isup accessed 30/03/16.

Chang, J. (2006) Native Tongues: An Interview with Cristina Verán. Retrieved from http://www.pbs.org/pov/borders/2006/talk/jeff_chang/000317.html accessed 28/03/16. 
Chappell, D.A. (1997). Double Ghosts, Oceanian Voyagers on Euro American Ships. London: M E Sharpe.

Che Fu (1998) $2 b$ S.Pacific [Album] New Zealand, BMG.

Clifford, James. (1997). “Diasporas.” In Routes: Travel and Translation in the Late $20^{\text {th }}$ Century. Cambridge, MA: Harvard University Press: 244-277.

Cochrane, S. (2000), Beretara: Contemporary Pacific Art, Sydney, Halstead Press. Published by Halstead Press, Sydney, 2000.

Cronin, A. (2015). Afakasi speaks. Metro Magazine, (October). Retrieved from https://www.noted.co.nz/archive/listener-nz-2015/afakasi-speaks/ accessed 10/01/16.

de Bres, J. (1999). "Dawn Raids and Migrant Workers: A contemporary Account of the 'Overstayer Crisis' 1974-1977". Wellington. Unpublished paper.

de Bres, J and R.J. Campbell. (1975). "Temporary Labour Migration Between Tonga and New Zealand. International Labour Review vol. 112, no. 6 (December): 445-457.

Deloitte, (2011). Working in an ideological echo chamber? Diversity of thought as a breakthrough strategy. Human Capital, Deloitte Australia Point of View.

Diaz, Vicente M, and J Kēhaulani Kauanui. (2001). "Native Pacific Cultural Studies on the Edge". The Contemporary Pacific 13(2): 315-342.

Dwyer, Krissy. (2013). Aaradhna wakes up to platinum news. Stuff.co.nz. Retrieved from Stuff.co.nz website: http://www.stuff.co.nz/entertainment/music/8231471/Aaradhna-wakes-upto-platinum-news accessed 17/03/16.

Eleveld, M., \& Smith, M.K. (2005). The Spoken Word Revolution: Slam, Hip-hop \& the Poetry of a New Generation. Sourcebooks MediaFusion.

Fairbairn-Dunlop, P., \& Makisi, G. S. (2003). Making our place: growing up PI in New Zealand. Palmerston North, N.Z: Dunmore Press.

Fatu, E., (2013). Creating the vā: A comparative review of artists Lily Laita and Niki Hastings Mc-Fall's reflection of Pacific Mixedness. Pacific Studies 489 comparative research thesis. Victoria University of Wellington. Unpublished.

Ferro, K., Wallner, M., \& Bedford, R. (2006). Migration happens: reasons, effects and opportunities of migration in the South Pacific (Vol. Bd. 4). Wien: Lit.

Fiji (George Veikoso) (2008) Indigenous Life. [Album] Hawaii, Indigenous Alliance. 
Franklin, M. I., (2003), I Define My Own Identity Pacific Articulations of 'Race' and 'Culture' on the Internet, Ethnicities 3: 465-490.

FRESH TV (2011, April 6) Aaradhna on Fresh TV - Part 1 [Video File] Retrieved from https://www.youtube.com/watch?v=_ZupA5tYQvk accessed 20/08/15.

FRESH TV (2013, January 13) Aaradhna hosts Fresh [Video File] Retrieved from https://www.youtube.com/watch?v=Eu3t-gK3djQ accessed 20/08/15.

Gershon, I. (2007) "Viewing Diasporas from the Pacific: What Pacific Ethnographies Offer Pacific Diaspora Studies.” The Contemporary Pacific 19(2): 474-502.

Gibson, L. (2003) Versioning for the love of it: Hip-Hop Culture in Aotearoa (Masters Thesis) Massey University, Palmerston North, Aotearoa New Zealand.

Gray, A. (2001). The definition and measurement of ethnicity: A Pacific perspective. Wellington, Grey Matter Research.

Goldberg, D. T. (2005). "Heterogeneity and Hybridity: Colonial Legacy, Postcolonial Heresy." In Sangeeta Ray \& Henry Schwarz (Ed.), A Companion to Postcolonial Studies. UK: Blackwell Publishing: 72-86.

Hall, S. and P. Du Gay. (1996). Questions of cultural identity, SAGE Publications Limited.

Hall, S. (1990). “Cultural Identity and Diaspora." In Rutherford, ed. Identity: Community, Culture, Difference. New York: New York University Press: 222-237.

Hastings, M., Grismer, C., Hunt, J.G., Warn, J (Directors). (2013). The Originals. In J. Plec (Producer), The Originals.

Hastings-McFall, Niki. (2013). In flyte. Exhibition catalogue. Pataka Art Gallery and Museum; Porirua, New Zealand. 2 February-16 June 2013.

Hastings-McFall, Niki, (2016) Tape-recorded interview material. 03 Mar 2016.

Hau'ofa, E. (1998) “The Ocean in Us.” The Contemporary Pacific, 10(2): 391-410.

Henderson, A. K. (2006) 'Dancing Between Islands: Hip Hop and Samoan Diaspora' in Dipannita Basu and Sidney J. Lemelle, eds, The Vinyl Ain't Final: Hip Hop and the Globalization of Black Popular Culture. (foreword by Robin DG Kelley). London: Pluto Press, 2006: 180-199.

Henderson, April K. (2012)"Māori Boys, Michael Jackson Dance Moves, and that 1984 Structure of Feeling." New Zealand Journal of Media Studies volume 13 number 1 (October): 79-96.

Hereniko, V. (1999). “Representations of Cultural Identities.” In Hereniko, V., \& Wilson, R., eds. Inside out: Literature, cultural politics, and identity in the new Pacific. Lanham, MD: Rowman \& Littlefield. 
Hollinshead, K. (1998). Tourism, hybridity, and ambiguity: The relevance of Bhabha's 'third space' cultures. Journal of Leisure Research, 30(1): 121.

Holt, A. A. (1999). Culture, ethnicity \& identity: a look at first generation children from immigrant Samoan families. University of Auckland.

Howe, K. R. (1979). Pacific Islands History in the 1980s: New Directions or Monograph Myopia? Pacific Studies, Vol 3, No. 1, 1979: 81-90; Huntsman, Judith (ed.), Introduction Tonga and Samoa: Images of Gender and Polity, Macmillan Brown Centre for Pacific Studies, Christchurch, 1995: 7-18.

Howe, K.R. (1988). “Whence and How?" In Where the Waves Fall, A new South Sea Islands history from first settlement to colonial rule, Sydney and London: George Allen \& Unwin: 3-24.

Hunkin-Tuiletufuga, G. (2001). "Pasefika languages and Pasefika identities: Contemporary and future challenges." In Macpherson, c., Spoonley, P., and Anae, M. eds, Tangata o Te Moana Nui: The evolving identities of Pacific peoples in Aotearoa. Palmerston North, NZ: Dunsmore Press: 196-211.

Kailahi, S. (2007). Pasifika Women: Our Stories in New Zealand: Raupo.

Ka'ili, T. (2005) "Tauhi vā: Nurturing Tongan Sociospatial Ties in Maui and Beyond," Contemporary Pacific 17(1): 83-114.

Ka'ili, T. (2008). "Tauhi Vā: Creating beauty through the art of sociospatial relations." Unpublished dissertation for the degree of Doctor of Philosophy, University of Washington.

Kaeppler, A. L. (1978). Exchange Patterns in Goods and Spouses: Fiji, Tonga and Samoa. Mankind, 11(3): 246-252.

Kame'eleihiwa, L. (1992) Native Land and Foreign Desires University of California: Bishop Museum Press.

Keddell, E. (2006) "Pavlova and pineapple pie: Selected identity influences on Samoan/Pākehā people in Aotearoa/New Zealand" Kotuitui: New Zealand Journal of Social Sciences Online, (1): 45-63.

Keddell, E. (2009) Narrative as Identity: Postmodernism, Multiple Ethnicities, and Narrative Practice Approaches in Social Work, Journal of Ethnic and Cultural Diversity in Social Work, 18:3: 221-241.

Kedgley, H. (2013) Niki Hastings-Mcfall, In Flyte, exhibition catalogue, 2 Feb - 16 June 2013, Pataka Museum.

Kirch, P. V. (2001). "Polynesian feasting in ethnohistorical, ethnographic, and archaeological contexts: A comparison of three societies." Feasts: Archaeological 
and Ethnographic Perspectives on Food, Politics, and Power. Washington DC: Smithsonian Institution Press: 168-184.

Koskoff, E. (Ed.). (n.d.). R\&B and Soul. In Garland Encyclopedia of World Music Volume 3 The United States and Canada (pp. 697-709). Routledge. Retrieved March 29, 2016, from Music Online: Garland Encyclopedia of World Music.

Koya Vaka'uta, Cresantia Frances. (2012). “Cyberspace, place, identity \& relationships: are we digitzing the Vā?" Panel presentation on Culture, Education and ICT Cultural Dynamics of the 21st Century International Conference on ICT \& Oceanian Cultures, University of the South Pacific Laucala Campus, Suva Fiji. Friday February 24th 2012. Available at http://works.bepress.com/cf_koyavakauta/13/accessed 29/03/16.

Liedtke, W. A., Dutch Paintings in the Metropolitan Museum of Art, Volumes 1-2. New York, Metropolitan Museum of Art, 2007.

Liki, A. (2009). Travelling daughters: Experiences of Melanesian-Samoan women. Development, 52(4): 537-543.

Lilomaiava-Doktor, S. (2009) 'Beyond Migration: Samoan population movement (Malaga) and the geography of social space (va)', The Contemporary Pacific 21 (1): 1-32.

Macpherson, C. (1999). Will the 'real' Samoans please stand up? Issues in diasporic Samoan identity. New Zealand Geographer, 55(2): 50-59.

Macpherson, C., Spoonley, P., \& Anae, M. (2001). Tangata o Te Moana Nui: the evolving identities of Pacific peoples in Aotearoa /New Zealand. Palmerston North, N.Z: Dunmore Press.

Mahina, O. (2007). From vale (ignorance) to 'ilo (knowledge) to poto (skill) the Tongan theory of ako (education): Theorising old problems anew. AlterNative: Ngā Pae o te Māramatanga, 4(1): 67-96.

Mahina, O. (2001). Ta Va and Faiva: The Tongan concept of time, space and art: unpublished paper presented at language, thought and reality: West-east perspectives. Paper presented at the Philosophy conference, Chicago State University of California, USA.

Mallon, S. (2004). "The art of inbetweeness; reflecting on Pacific art practice in New Zealand" SPAN Journal of the South Pacific Association For Commonwealth Literature and Language Studies (53): 44-56.

Mallon, S., Māhina-Tuai, K. U., \& Salesa, D. I. (2012). Tangata o le Moana: New Zealand and the people of the Pacific. Wellington, N.Z: Te Papa Press.

Mallon, S., \& Pereira, P. F. (1997). Speaking in colour: conversations with artists of Pacific Island heritage. Wellington, N.Z: Te Papa Press. 
Mallon, S., \& Pereira, P. F. (2002). Pacific art NiuSila: the Pacific dimension of contemporary New Zealand arts. Wellington, N.Z: Te Papa Press.

Manuela, S., \& Sibley, C. G. (2012). The Pacific Identity and Wellbeing Scale (PIWBS): A culturally-appropriate self-report measure for Pacific peoples in New Zealand. Social Indicators Research.

Marsh, S.T. (2009). Fast talking PI. Auckland, N.Z: Auckland University Press.

Meleisea, M. (1980). O tama uli: Melanesians in Western Samoa. Suva, Fiji: Institute of Pacific Studies, University of the South Pacific.

Mila, K. (2005). Dream fish floating. Wellington, N.Z: Huia Publishers.

Mila-Schaaf, K. (2006) "Vä-centred social work: Possibilities for a Pacific approach to social work practice." Social Work Review (August): 8-13.

Mila-Schaaf, K. (2011). "Polycultural Capital and the Pasifika Second Generation:

Negotiating Identities". Integration of Immigrants Programme.

Mila-Schaaf, K., \& Robinson, E. (2010). "Polycultural capital and educational achievement among NZ-born Pacific peoples". Mai Review, 1: 1-18.

Ministry of Health. (2008). Pacific Peoples and Mental Health: A paper for the Pacific Health and Disability Action Plan review. Wellington: Ministry of Health. https://www.mentalhealth.org.nz/assets/ResourceFinder/pacific-peoples-andmenta-health-may08.pdf accessed 29/03/16.

Morley, D and Chen, K-H, (1996) eds. Stuart Hall: Critical Dialogues in Cultural Studies. London \& New York: Routledge: 262-275.

Mulitalo, T. (2001). My own shade of brown. Christchurch, N.Z: University of Canterbury School of Fine Arts in association with Shoal Bay Press.

Museum of New Zealand Te Papa Tongarewa. (2011, Oct 20). Recycled Plastic Art - Tales from Te Papa episode 91. [Video File]. Retrieved from https://www.youtube.com/watch?v=UdQ-e_ihdJ0 accessed 2013.

New Zealand Education and Training Support Agency. Pacific Islands Education Trust (1998) Our Place in the Sun, Wellington, New Zealand: Pacific Islands Education Unit.

NZ Idol (2006-03) Idol Blog. Retrieved from: http://www.idolblog.com/accessed 28/03/16. 
NZ on Air (2012) Broadcast programming For Pacific Audiences [pdf]. Retrieved from: http://www.nzonair.govt.nz/research/all-research/broadcast-programmingfor-pacific-audiences-june-2012/accessed 27/03/16.

New Zealand Herald, (2013). "NZ Music Awards: Aaradhna interview". http://m.nzherald.co.nz/entertainment/news/video.cfm?c_id=1501119\&gallery _id=139246\&gal_objectid=11160876 accessed 29/03/13.

Niu Voices, (2006) Niu Voices: Contemporary Pacific fiction, 1. Huia Publisher. Wellington, N.Z.

'Olaf Nelson and the place of afakasi in Samoa', URL: http://www.nzhistory.net.nz/media/photo/olaf-nelson-and-place-afakasisamoa, (Ministry for Culture and Heritage), updated 2-Sep-2014.

Oliver, H. (2015) Aaradhna: "I'm just trying to be heard" Retrieved from http://www.stuff.co.nz/entertainment/71516629/aaradhna-im-just-trying-tobe-heard accessed 16/02/16.

Pasifika Styles, from http://www.pasifikastyles.org.uk accessed 09/10/2013.

Pearson, S. (2004) Pasifika/NZ frontiers - New Zealand-Samoan Hip hop, music video and diasporic space. Perfect Beat, 6(4): 411 - 432.

Phinney, J. S., \& Devich-Navarro, M. (1997). Variations in bicultural identification among African American and Mexican American adolescents. Journal of Research on Adolescence, 7(1), 3-32.

Pollock, N. J. (1992). These Roots Remain: Food Habits in Islands of the Central and Eastern Pacific Since Western Contact. Honolulu: University of Hawai'i Press.

Pumar, P. (2005). Cultural Studies and Rap: The Poetry of an Urban Lyricist, Taboo Spring Summer Vol 9, No. 1: 5-17.

Radio New Zealand (2013) Aaradhna sweeps Pacific Music Awards in NZ, Retrieved from: http://www.radionz.co.nz/international/pacific-news/212594/aaradhnasweeps-pacific-music-awards-in-nz accessed 17/08/15.

Robins, S (2008). Interview with Niki Hastings McFall in "Kōrero

Mai," an audio series accompanying the exhibition Pasifika Styles. University of Cambridge Museum of Archaeology and Anthropology: Cambridge, UK, 2008.

Retrieved from http://www.pasifikastyles.org.uk/artists/niki-hastingsmcfall.php accessed 09/10/2013.

Rolls, L. (director). (2004). Children of the migration. 78min. Wellington, N.Z. Island Productions.

Safran, W.(1991) Diaspora: A Journal of Transnational Studies, Volume 1, Number 1, Spring 1991: 83-99. 
Salesa T. D., (2000) Half-castes between the Wars Colonial Categories In New Zealand And Samoa New Zealand Journal of History 34(1): 98-116

Salesa, T Damon I. (2003). 'Travel-happy' Samoa: Colonialism, Samoan migration and a 'Brown Pacific'. New Zealand Journal of History, 37(2): 171-188.

Salesa, D. I. (2006). Samoa's Half-Castes and Some Frontiers of Comparison. In A. L. Stoler (Ed.) Haunted by Empire: Geographies of Intimacy in North American History. Durham, North Carolina: Duke University Press: 72-93).

Scherer, J. (2015) X Factor recap: A very Kiwi X Factor final. Retrieved from: http://www.stuff.co.nz/entertainment/tv-radio/68620076/X-Factor-recap-Avery-Kiwi-X-Factor-final accessed 29/03/16.

Sharrad, P. (2003). Albert Wendt and pacific literature: Circling the Void. Manchester University Press.

Short, J. (2011). All of My Blood is Red: Contemporary Metis Visual Culture and Identity, Faculty of Social Sciences, Brock University.

Shelley, M. Frankenstein (1831) Oxford: Oxford University Press, 1998.

Spickard, P. R. (1989). Mixed Blood: Intermarriage and Ethnic Identity in TwentiethCentury America. Mafison, WI: University of Wisconsin Press.

Spickard, P. R., et al. (2002). Pacific diaspora: Island peoples in the United States and across the Pacific. Honolulu: University of Hawaii Press.

Song, A. (2003). Choosing ethnic identity. Oxford: Polity Press.

Spencer, S. (2014). Race and ethnicity: culture, identity and representation (second edition). New York: Routledge.

Spoonley, P., Pearson, D. G., \& Macpherson, C. (1996). Ngā Patai: racism and ethnic relations in Aotearoa/New Zealand. Palmerston North, N.Z: Dunmore Press.

Spoonley, P., Pearson, D. G., \& Macpherson, C. (2004). Tangata, tangata: the changing ethnic contours of New Zealand. Southbank, Victoria: Dunmore Press.

Statistics New Zealand (2007). QuickStats about Culture and Identity: 2006 Census: Statistics New Zealand, Wellington.

Statistics New Zealand (2008). QuickStats About Pacific Peoples: 2006 Census: Statistics New Zealand.

Statistics New Zealand (2014). Samoan people in New Zealand: 20013. Statistics New Zealand. 
Statistics New Zealand (2014). Tongan people in New Zealand: 2013. Statistics New Zealand.

Statistics New Zealand (2014). Niuean people in New Zealand: 2013. Statistics New Zealand.

Statistics New Zealand (2009). Young people 1986-2006: Relationship change. Wellington: Statistics New Zealand.

Stevenson, K. (2002) “The Festival of Pacific Arts: Its Past, Its Future.” Pacific Arts, 25, Festival of Pacific Arts: 31-40.

Stevenson, K. (2008). The Frangipani is Dead: Contemporary Pacific Art in New Zealand. New Zealand: Huia Publishers.

Spoonley, P \& Pearson, D.G. (2004) Tangata Tangata: The Changing Ethnic Contours of New Zealand. Cengage Learning Australia.

Tagata Pasifika, (2013, Feb 23). Tagata Pasifika Music Special. [Video File]. Retrieved from https://www.youtube.com/watch?v=uAsjLYjvp_w accessed 30/12/16.

Tamaira, A. M. (2009). The space between: negotiating culture, place, and identity in the Pacific (Occasional Papers Series Vol. 44). Honolulu: Center for Pacific Islands Studies, School of Hawaiian, Asian \& Pacific Studies, University of Hawai'i at Mānoa.

Tamasese, Kiwi, Carmel Peteru, Charles Waldegrave, Allister Bush (2005). "Ole Taeao Afua, the new morning: a qualititative investigation into Samoan persoectives on mental health and cultural appropriate services." Australian and New Zealand Journal of Psychiatry Vol 39: 300-309.

Tautai Pacific Contemporary Arts Trust, retrieved from http://www.tautai.org/ accessed 09/10/2013.

Tapaleao, V. (2014). "Tattoo you: Aaradhna singer". New Zealand Herald. http://www.nzherald.co.nz/lifestyle/news/article.cfm?c_id=6\&objectid=113804 $\underline{07}$ accessed 30/03/16.

Taylor, G. (2013). "Afakasi is Dead". YouTube. Retrieved from https://www.youtube.com/watch?v=5JWyKWWgyxY accessed 28/03/16.

Taylor, G. [TEDx Talks]. (2013, Sep 3). The power of words: Grace Taylor at TEDxAuckland. [Video file]. Retrieved from https://www.youtube.com/watch?v=LivPMiYik9g accessed 28/03/16.

Taylor, G. [The Coconut.tv]. (2015). Tinā by Grace Taylor. [VideoFile]. Retrieved from http://www.thecoconet.tv/creative-natives/tina-by-grace-taylor/accessed 28/03/16. 
Taylor, G. (2015). “Hidden Aucklanders”. Radio New Zealand. http://www.radionz.co.nz/national/programmes/standing-roomonly/audio/201774143/hidden-aucklanders accessed 28/03/16.

Taylor, G. [South Auckland Poets Collective]. (2011, Jun 20). Spoken Word: "Being Afakasi" by Grace Taylor. [Video File]. Retrieved from https://www.youtube.com/watch?v=ruizDW9Lg0Q accessed 28/03/16.

Taylor, G.T.E. (2013) Afakasi Speaks. Honolulu, Hawai'i: Ala Press.

Taylor, G. (2015). "My Own Darling”. On- Stage information pamphlet. Auckland Theatre Company. Vol 1. No. 10. Oct 2015. Auckland.

Teaiwa, K. M. (2007). South Asia Down Under: Popular Kinship in Oceania. Cultural Dynamics, 19: 193-232.

Teaiwa, T. K. \& Henderson, A. K, "Humanities and Communities: A Dialogue in Pacific Studies," in Pacific Studies, 32(4), 2009/2010: 421-438.

Teaiwa, T. K. \& Mallon, S. (2005) "Ambivalent kinships? Pacific people in New Zealand" in Liu, J., McCreanor, T., McKintosh, T. and Teaiwa, T., eds, New Zealand identities: Departures and destinations. Wellington, N.Z.: Victoria University Press: 207-229.

Teaiwa, T. K. \& Marsh, S. T, (2010). “Albert Wendt's Creative and Critical Legacy in Oceania: An Introduction”. The Contemporary Pacific 22(2): 233-248.

Teaiwa, T. K. (2005). "Native Thoughts: A Pacific Studies Take on Cultural Studies and Diaspora," in Graham Harvey and Charles Dillard Thompson, eds. Indigenous Diasporas and Dislocations. London: Ashgate: 15-36.

Tiatia, J., \& Deverell, G. (1998). Caught between cultures: a New Zealand-born Pacific Island perspective. Auckland [N.Z.]: Christian Research Association.

Tim Thorpe Consulting Ltd, Catalyst Pacific Ltd, and SDL Consultancy Ltd, in association with Emma Powell and April Henderson, (2012). "Broadcast Programming for Pacific Audiences in New Zealand: A Research Report for NZ On Air." Available at: http://www.nzonair.govt.nz/document-library/broadcast-programming-forpacific-audiences-june-2012/ accessed 27/02/16.

Thaman, K.H. (2008) "Nurturing relationships and honouring responsibilities: A Pacific perspective", International Review of Education. 54: 459-473.

Thaman, K. H. (2010) "Teacher capacities for working towards peace and sustainable development", International Journal of Sustainability in Higher Education, Vol. 11 Iss: $4: 53-364$.

Thrasher, F. M. (1936). The gang: A study of 1,313 gangs in Chicago. Chicago: University of Chicago Press. 
Tuimaleali'ifano, M. A. (1990). Samoans in Fiji: Migration, identity and communication. Suva, Fiji: Institute of Pacific Studies, Fiji, Tonga, and Western Samoa Extension Centres of the University of the South Pacific.

Tuffery, M, (2012). "First Contact". Museum of New Zealand Te Papa Tongarewa.

Tui Atua Tupua Tamasese Taisi Efi, (2003). "In Search of Meaning, Nuance and Metaphor in Social Policy." Social Policy Journal of New Zealand. Issue 20 (June): 49-63.

Tupuola, A. (2004). Raising consciousness the Fa'a Samoa way.New Zealand Annual Review of Education. 3, 175 189. Velez-Iabanez, C., \& Greenberg, J. (1992). Formation and transformation of funds of knowledge among U.S. Mexican useholds. Anthropology and Education Quarterly, 23(4),:313-315.

Turnbull, L. (2008, 28 Sept). "This is who I am: Defining mixed-race identity." The Seattle Times. Retrieved from https://www.seattletimes.com/seattle-news/thisis-who-i-am-defining-mixed-race-identity/ accessed on 20/04/18.

Walrond, C. (2015) "Cook Islanders - Culture", in Te Ara - the Encyclopedia of New Zealand. First publish 8/02/05. Retrieved from https://teara.govt.nz/en/artwork/861/artworks-by-ani-oneill accessed on 20/04/18, accessed on 20/04/18.

Webb-Binder, B. (2009). Pacific Identity through Space and Time in Lily Laita's Va i Ta. In Tamaira, A. M. (2009). The space between: negotiating culture, place, and identity in the Pacific (Vol. 44). Honolulu: Center for Pacific Islands Studies, School of Hawaiian, Asian \& Pacific Studies, University of Hawai'i at Mānoa: 2534.

Webber, M. (2008). Walking the space between: Identity and Maori/Pakeha: NZCER Press (New Zealand Council for Educational Research).

Webster, F. (2004). "Cultural Studies and Sociology At, And After, the Closure of the Birmingham School." Cultural Studies 18(6): 847-862.

Wendt, A., (1976) "Towards a New Oceania." Mana Review: A South Pacific Journal of Language and Literature 1 (1) (January): 49-60. Reprinted in A Pacific Islands Collection: Cook Islands, Fiji, New Zealand, Niue, Papua New Guinea, Solomon Islands, Tonga, Vanuatu, Western Samoa, edited by Richard Hamasaki. Seaweeds and Constructions 7:71-85. Printed by Elepaio Press. Honolulu: Richard Hamasaki, 1983.

Wendt, A. (1983). "Contemporary Arts in Oceania: Trying to Stay Alive in Paradise as an Artist." In S. M. M. a. B. Kernot (Ed.), Art and Artists of Oceania. Palmerston North, NZ: Dunmore Press: 198-209.

Wendt, A. (1996). “Tatauing the Post Colonial Body”. Span 42-43 (April - October): 1529. 
Wendt, A. (2000). "Pacific Identities, Pacific Writing." In Brij V. Lal and Kate Fortune, eds. The Pacific Islands: An Encyclopedia. Honolulu: University of Hawai'i Press, 2000: 516-517.

Wesley-Smith, T. (1995) "Rethinking Pacific Islands Studies”. Pacific Studies. Vol. 18, No. 2: 115-136.

Whimp, G. (2009). Working in the Space Between: Pacific Artists in Aotearoa/New Zealand In Tamaira, A. M. (2009). The space between: negotiating culture, place, and identity in the Pacific (Vol. 44). Honolulu: Center for Pacific Islands Studies, School of Hawaiian, Asian \& Pacific Studies, University of Hawai'i at Mānoa: 9-23

Wilson, C., (2013) 'That's My Stuff' Pasifika Literature and Pasifika Identity [Masters Thesis] Wellington, Victoria University of Wellington.

Wood, H. 2003. "Cultural Studies for Oceania”. The Contemporary Pacific 15 (2): 340374.

Yazdiha, H. (2010). Conceptualizing Hybridity: Deconstructing Boundaries through the Hybrid. Formations, 1(1): 31-38.

YouKnow IGotSoul. (2013, Jun 19). Aaradhna Interview - New Zealand's Finest With a Retro- Metro Vibe. [Video File]. Retrieved from https://www.youtube.com/watch?v=7QT73wmkOZQ accessed 30/10/15.

Zemke, K. and Televave S. S. 2011. "Pasifika r 'n' b Divas: gender, culture and identity in Pacific pop music in New Zealand". In Keam G. and T. Mitchell (eds.) Situating Music in Aotearoa/New Zealand. Pearson Education NZ: 21-30.

Zemke-White, K. M. (2005). “Nesian Styles (re)present R'n'B: The appropriation, transformation and realization of contemporary R'n'B with hip hop by urban Pasifika groups in Aotearoa". Sites: a Journal of Social Anthropology and Cultural Studies, 2 (1): 94-123. 